\title{
Hammerhead flatworms (Platyhelminthes, Geoplanidae, Bipaliinae): mitochondrial genomes and description of two new species from France, Italy, and Mayotte
}

Jean-Lou Justine Leigh Winsor

${ }^{1}$ ISYEB - Institut de Systématique, Évolution, Biodiversité, Muséum National d'Histoire Naturelle, Paris, France

3 Amateur naturalist, Unaffiliated, Cagnes-sur-Mer, France

4 Molécules de Communication et Adaptation des Micro-Organismes, Muséum national d'Histoire naturelle, Paris, France

Department of Agronomy, Food, Natural Resources, Animals and the Environment (DAFNAE), Padova, Italy

${ }^{6}$ Muséum de Bordeaux, Bordeaux, France

7 James Cook University of North Queensland, Townsville, Queensland, Australia

Corresponding Author: Jean-Lou Justine

Email address: justine@mnhn.fr

Background. New records of alien land planarians are regularly reported worldwide, and some correspond to undescribed species of unknown geographic origin. The description of new species of land planarians (Geoplanidae) should classically be based on both external morphology and histology of anatomical structures, especially the copulatory organs, ideally with the addition of molecular data. Methods. Here, we describe the morphology and reproductive anatomy of a species previously reported as Diversibipalium "black", and the morphology of a species previously reported as Diversibipalium "blue". Based on next generation sequencing, we obtained the complete mitogenome of five species of Bipaliinae, including these two species. Results. The new species Humbertium covidum n. sp. (syn: Diversibipalium "black" of Justine et al., 2018) is formally described on the basis of morphology, histology and mitogenome, and is assigned to Humbertium on the basis of its reproductive anatomy. The type-locality is Casier, Italy, and other localities are in the Department of Pyrénées-Atlantiques, France; some published or unpublished records suggest that this species might also be present in Russia, China, and Japan. The mitogenomic polymorphism of two geographically distinct specimens (Italy vs France) is described; the cox1 gene displayed $2.25 \%$ difference. The new species Diversibipalium mayottensis n. sp. (syn: Diversibipalium "blue" of Justine et al., 2018) is formally described on the basis of external morphology and complete mitogenome and is assigned to Diversibipalium on the basis of an absence of information on its reproductive anatomy. The type- and only known locality is the island of Mayotte in the Mozambique Canal off Africa. 
Phylogenies of bipaliine geoplanids were constructed on the basis of SSU, LSU, mitochondrial proteins and concatenated sequences of cox 1 , SSU and LSU. In all four phylogenies, $D$. mayottensis was the sister-group to all the other bipaliines. With the exception of $D$. multilineatum which could not be circularised, the complete mitogenomes of $B$. kewense, $B$. vagum, $B$. adventitium, $H$. covidum and $D$. mayottensis were colinear. The $16 \mathrm{~S}$ gene in all bipaliine species was problematic because usual tools were unable to locate its exact position. Conclusion. Next generation sequencing, which can provide complete mitochondrial genomes as well as traditionally used genes such as SSU, LSU and cox1, is a powerful tool for delineating and describing species of Bipaliinae when the reproductive structure cannot be studied, which is sometimes the case of asexually reproducing invasive species. The unexpected position of the new species $D$. mayottensis as sister-group to all other Bipaliinae in all phylogenetic analyses suggests that the species could belong to a new genus, yet to be described. 


\section{Hammerhead flatworms (Platyhelminthes, Geoplanidae, Bipaliinae):}

2 mitochondrial genomes and description of two new species from France,

3 Italy, and Mayotte

5 Jean-Lou Justine ${ }^{1}$, Romain Gastineau ${ }^{2}$, Pierre Gros ${ }^{3}$, Delphine Gey ${ }^{4}$, Enrico Ruzzier ${ }^{5}$, 6 Laurent Charles ${ }^{6}$, Leigh Winsor ${ }^{7}$

81 ISYEB - Institut de Systématique, Évolution, Biodiversité, Muséum National d'Histoire

9 Naturelle, Paris, France

102 Institute of Marine and Environmental Sciences, University of Szczecin, Szczecin, Poland

113 Amateur naturalist, Unaffiliated, Cagnes-sur-Mer, France

124 Molécules de Communication et Adaptation des Micro-Organismes, Muséum national

13 d'Histoire naturelle, Paris, France

145 Department of Agronomy, Food, Natural Resources, Animals and the Environment

15 (DAFNAE), Padova, Italy

166 Muséum de Bordeaux, Bordeaux, France

177 James Cook University of North Queensland, Townsville, Queensland, Australia

19 Corresponding Author: Jean-Lou Justine

20 Email address: justine@mnhn.fr 


\section{Abstract}

23 Background. New records of alien land planarians are regularly reported worldwide, and some 24 correspond to undescribed species of unknown geographic origin. The description of new species of land planarians (Geoplanidae) should classically be based on both external morphology and histology of anatomical structures, especially the copulatory organs, ideally with the addition of molecular data.

Methods. Here, we describe the morphology and reproductive anatomy of a species previously reported as Diversibipalium "black", and the morphology of a species previously reported as Diversibipalium "blue". Based on next generation sequencing, we obtained the complete mitogenome of five species of Bipaliinae, including these two species.

Results. The new species Humbertium covidum n. sp. (syn: Diversibipalium "black" of Justine et al., 2018) is formally described on the basis of morphology, histology and mitogenome, and is assigned to Humbertium on the basis of its reproductive anatomy. The type-locality is Casier, Italy, and other localities are in the Department of Pyrénées-Atlantiques, France; some published or unpublished records suggest that this species might also be present in Russia, China, and Japan. The mitogenomic polymorphism of two geographically distinct specimens (Italy vs France) is described; the coxl gene displayed $2.25 \%$ difference. The new species Diversibipalium mayottensis n. sp. (syn: Diversibipalium "blue" of Justine et al., 2018) is formally described on the basis of external morphology and complete mitogenome and is assigned to Diversibipalium on the basis of an absence of information on its reproductive anatomy. The type- and only known locality is the island of Mayotte in the Mozambique Canal off Africa. Phylogenies of bipaliine geoplanids were constructed on the basis of SSU, LSU, mitochondrial proteins and concatenated sequences of coxl, SSU and LSU. In all four phylogenies, D. mayottensis was the sister-group to all the other bipaliines. With the exception of $D$. multilineatum which could not be circularised, the complete mitogenomes of $B$. kewense, $B$. vagum, $B$. adventitium, $H$. covidum and D. mayottensis were colinear. The $16 \mathrm{~S}$ gene in all bipaliine species was problematic because usual tools were unable to locate its exact position.

Conclusion. Next generation sequencing, which can provide complete mitochondrial genomes as well as traditionally used genes such as SSU, LSU and coxl, is a powerful tool for delineating 
51 and describing species of Bipaliinae when the reproductive structure cannot be studied, which is 52 sometimes the case of asexually reproducing invasive species. The unexpected position of the 53 new species D. mayottensis as sister-group to all other Bipaliinae in all phylogenetic analyses 54 suggests that the species could belong to a new genus, yet to be described. 


\section{Introduction}

56 Many new records of alien land planarians (Geoplanidae) have been published in recent years; some correspond to already known species found in new locations, but some are in fact undescribed species, never mentioned in other countries and for which the location of origin is unknown. Recent typical examples include Obama nungara Carbayo et al., 2016, a species from South America now invasive in Europe, for which taxonomic confusion has obscured the debate over the last decade (Carbayo et al. 2016; Justine et al. 2014a; Lago-Barcia et al. 2015) and Caenoplana decolorata Mateos et al., 2020, probably from Australia (Justine et al. 2020b; Mateos et al. 2020). In addition to the scientific need for precision, it is important to ascribe precise binomial names to invasive species for administrative purposes.

Although some land planarians show brilliant colours and patterns, these are generally not sufficient for describing species. A formal description should classically be based on both external morphology and microanatomy including that of the copulatory organs, obtained by histological techniques. Modern descriptions generally add partial sequences of a few genes. However, some invasive species have abandoned sexual reproduction and thus lack most characters usable for taxonomy.

Hammerhead flatworms (subfamily Bipaliinae) are among the most spectacular land flatworms, with one species, Bipalium nobile Kawakatsu \& Makino, 1982, reaching one metre in length (see Table 1 for authors of taxa and key references). In a taxonomic revision of the Bipaliinae, a collective group, the genus Diversibipalium Kawakatsu, Ogren, Froehlich \& Sasaki, 2002, was erected to accommodate uncertain bipaliid species that had descriptions based on immature specimens, or mature specimens whose internal anatomy, including that of the copulatory organs, has not yet been investigated (Kawakatsu et al. 2002). All the species assigned to this collective genus are described only on the basis of external morphology and colour pattern. In 2018, we reported two species and assigned them to Diversibipalium, but we did not create binomial names; instead, the species were designated as Diversibipalium "black", found in a

81 single place in France, and Diversibipalium "blue", found only on the island of Mayotte, off 82 Africa (Justine et al. 2018). 
83 Histology is a technique that requires specialised skills and experience in interpreting sections. In 84 contrast, the development of next generation sequencing technologies (NGS) has made it easier

85 86 and cheaper to obtain sequences. It is now possible to sequence the organellar genomes of various organisms with a satisfactory rate of success. For land planarians, the first complete mitogenome was described in 2015 (Solà et al. 2015) from a specimen of Obama sp., since then considered to be Obama nungara Carbayo et al., 2016 (Carbayo et al. 2016). Recently, our group supplemented the databases with complete mitogenomes from several other invasive species, namely Bipalium kewense (Gastineau et al. 2019), Platydemus manokwari de Beauchamp, 1963 (Gastineau et al. 2020), Parakontikia ventrolineata (Dendy, 1892) (Gastineau \& Justine 2020), and Amaga expatria Jones \& Sterrer, 2005 (Justine et al. 2020a).

Complete mitogenomes provide a different type of data for molecular identification and phylogeny when compared with the usual molecular markers such as the short and long subunits of the nuclear ribosomal RNA genes (SSU and LSU, respectively). Indeed, the organisation of the mitogenome itself, like gene order, gene composition and the presence of pseudo-genes, can provide an additional phylogenetic signal. Based on our previous experience, phylogenetic trees inferred from mitochondrial protein-coding gene alignments display strong support at their nodes, congruent with taxonomy, classification and biogeography (Justine et al. 2020a). Also, the use of next generation sequencing rather than PCR coupled with Sanger to obtain mitochondrial genes limits the risk of amplifying nuclear pseudogene copies of mitochondrial DNA, aka numts, which have proven to be a real problem for phylogeny and molecular taxonomy (Song et al. 2008; Buhay 2009; Hlaing et al. 2009; Hazkani-Covo et al. 2010; Leite 2021; Andújar et al. 2021; Graham et al. 2021). However, as only 5 mitogenomes of Geoplanidae were available before this study, there remains a considerable amount of sequencing and documentation of additional taxa yet to be completed. We describe here for the first time the mitochondrial genomes of three already known species of Bipaliinae, namely $B$. vagum, B. adventitium and D. multilineatum, and we provide a map for B. kewense which was briefly reported without a map (Gastineau et al. 2019).

In this paper, for the species previously referred as Diversibipalium 'black' (Justine et al. 2018), additional material was obtained and we were able to prepare a formal description that includes morphology, histology and molecular phylogenies based on complete mitochondrial genome and 
113 nuclear ribosomal genes, and to finally assign this species, on the basis of its anatomy, to the

114 genus Humbertium Ogren \& Sluys, 2001.

115 For the second species, Diversibipalium 'blue', the low number of samples precluded

116 histological investigation, but enough DNA was obtained for us to perform next generation

117 sequencing and retrieve its full mitochondrial genome and nuclear ribosomal genes. We describe

118 it as a new species of the genus Diversibipalium, which by definition does not imply any

119 phylogenetic relationships except its appurtenance to the subfamily Bipaliinae. However, all

120 phylogenies inferred from our molecular results positioned this species as the sister-group to all

121 other Bipaliinae, thus suggesting that the species belongs to a different genus yet to be described.

\section{Material \& Methods}

\section{Collection of specimens}

124 New specimens of Diversibipalium "black" were provided in the context of a Citizen Science 125 initiative (Justine et al. 2014b, 2015, 2018, 2020a, 2020c, 2021) by Mrs Geneviève Rolland-

126 Martinez, from her garden in Billère, Department of Pyrénées-Atlantiques, France. One of us

127 (ER) collected numerous specimens in a private home garden located in Casier, Province of

128 Treviso, Italy. In both cases, living specimens were sent by post to PG for photography and JLJ

129 and RG for molecular work. Specimens were deposited in the Muséum National d'Histoire

130 Naturelle in Paris, France (MNHN). A specimen of B. adventitium was collected in ethanol in

131 Montréal, Québec, Canada on 27 May 2018 by Thomas Théry and deposited as MNHN JL328

132 (Justine et al. 2019). A specimen of B. vagum was collected in ethanol in Morne Vert,

133 Martinique, Caribbean, on 19 November 2015 by Mathieu Coulis and deposited as MNHN

134 JL307 (Justine et al. 2018).

\section{Histology}

136 The specimens were killed in boiling water and fixed in 95\% pure ethanol for molecular studies.

137 Specimens for histology were processed and stained by methods provided by Winsor \& Sluys

138 2018. As the specimens were brittle, they were gradually hydrated through a series of descending

139 ethanol solutions to water and softened in Sandison's fluid until flexible (weeks). Specimens

140 were then divided into anterior, pre-pharyngeal and posterior pieces, rinsed in water, and 
141 dehydrated in an ascending ethanol series to $95 \%$ ethanol-5\% phenol, transferred to

142 Supercedrol ${ }^{\circledR}$ (G.T. Gurr Ltd), and infiltrated and embedded in Paraplast ${ }^{\circledR}$ paraffin wax, melting

143 point $56^{\circ} \mathrm{C}$ (McCormick Scientific). Tissue blocks were sectioned at $7 \mu \mathrm{m}$ using a Leitz 1212

144 rotary microtome, mounted on glass slides with Mayer's albumen adhesive, stained by Cason's

145 modification of Mallory's trichrome along with control sections, and mounted in Entellan ${ }^{\circledR}$ New

146 (Merck-Millipore).

147 Calculation of the Cutaneous Muscular Index (CMI) follows that of Froehlich 1955 and

148 calculation of the Parenchymal Muscular Index (PMI) that of Winsor 1983.

149 Cox1 and LSU sequences obtained by Sanger method

150 Coxl and LSU sequences were obtained by Sanger sequencing as detailed in Justine et al. 151 (2018).

152 We built a tree and evaluated distances between all partial cox 1 sequences available for the 153 species previously referred to as Diversibipalium "black" from three localities. All alignment and 154 analyses were conducted with MEGA7 (Kumar et al. 2016). After choosing the best model, 155 which was the Hasegawa-Kishino-Yano model, an ML tree was constructed (Hasegawa et al. 156 1985). A neighbour-joining (NJ) tree was constructed for comparison. Distances were analysed

157 following routine methods (Justine et al. 2018).

158 Next generation sequencing and phylogeny

159 Samples of tissues conserved in ethanol 70\% were sent to the Beijing Genomics Institute (BGI-

160 Shenzhen), which performed DNA extraction, library preparation and sequencing on a DNBSEQ

161 platform. For each sample, a total of ca. 60 million clean $100 \mathrm{bp}$ paired-end reads were obtained 162 and assembled using SPAdes 3.14.0 (Bankevich et al. 2012) with a k-mer of 85. The contigs 163 corresponding to mitogenomes were verified using Consed (Gordon et al. 1998). Genes were 164 identified with the help of MITOS (Bernt et al. 2013), but also required manual curation on 165 several occasions. rRNAs were obtained by alignments with reference sequences from $O$. 166 nungara and B. kewense, and tRNAs were found using MITOS. In some cases, tRNAs were also 167 checked with ARWEN command line using the -gcflatworm option (Laslett and Canbäck 2008). 168 All genomic maps were drawn using OGDRAW (Lohse et al. 2013). LOGOs were obtained from 
169 WebLogo3 online (Crooks et al. 2004). When needed, alignments were printed out using

170 GenDoc (Nicholas et al. 1997).

171 SSU and LSU sequences were retrieved from the contig files obtained after assembly, by basic

172 data mining using blastn command line and earlier references obtained by PCR as a database

173 (Boratyn et al. 2012).

174 Four separate phylogenies were constructed, based on the partial nuclear ribosomal small subunit

175 gene (SSU), the partial nuclear ribosomal large subunit gene (LSU), the concatenated amino-acid

176 sequences of all mitochondrial proteins, and concatenated cox1, SSU and LSU genes. For SSU,

17714 different sequences were used, and 20 for LSU with, in both cases the Geoplaninae $O$.

178 nungara and $A$. expatria as outgroups. For the mitochondrial protein phylogeny, sequences

179 obtained from 19 organisms were used, but here the outgroup was Prosthiostomum siphunculus

180 Delle Chiaje, 1822 (Polycladida). The 3-gene phylogeny (cox1, SSU, LSU) was performed on

181 the same species as those included in the mitochondrial protein phylogeny, minus those for

182 which SSU or LSU data were missing, plus the species Novibipalium venosum (Kaburaki, 1922)

183 and Bipalium nobile, for which cox1 sequences HM346599 and MG436936 were used,

184 respectively. Otherwise, all coxl sequences were derived from whole mitogenomes, and SSU

185 and LSU sequences correspond to those included in their respective trees. In total, 19 organisms

186 were included in the 3-gene phylogeny. The single genes and concatenated sequences were

187 aligned using MAFFT 7 (Katoh \& Standley 2013) with the -auto function. For both concatenated

188 datasets, the resulting alignments were trimmed by trimAl (Capella-Gutiérrez et al. 2009) with

189 the -automated 1 function. The final sizes of the trimmed alignments were 2587 AA for the

190 mitochondrial protein dataset and $3447 \mathrm{bp}$ for the 3-gene dataset. For the SSU, LSU and 3-gene

191 phylogenies, the evolution model was GTR $+\mathrm{I}+\mathrm{G}$, chosen according to jModelTest2 (Darriba et

192 al 2012), while for the mitochondrial protein phylogeny it was mtART $+\mathrm{I}+\mathrm{G}$, chosen $a d$ hoc as a

193 model for mitochondrial protein coding genes of invertebrates (Abascal et al. 2007). Maximum

194 likelihood (ML) phylogenies were all conducted using RaxML 8.0 (Stamatakis 2014), with the

195 best tree out of 100 being computed for 1000 bootstrap replicates. Bayesian inference (BI)

196 phylogenies were conducted on MrBayes 3.2.7 (Ronquist et al. 2012) using the default

197 parameters, on alignments transformed into the nexus format by ALTER (Glez-Peña et al. 2012).

198 Due to the absence of the mtART model in MrBayes 3.2.7, no BI phylogeny was performed on 
199 the concatenated mitochondrial protein sequences. The average standard deviations of split

200 frequencies attained by MrBayes at the end of the run were $0.005317,0.003415$ and 0.001453

201 for the SSU, LSU and 3-gene phylogenies, respectively.

\section{Detection of alien DNA}

203 For all the samples sequenced in this study, data mining was performed on the contigs obtained 204 after assembly to find potential traces of alien DNA, using blastn command line (Boratyn et al.

205 2012) and a database consisting of SSU sequences from Eisenia fetida Savigny, 1826

206 (EF534709), Helix aspersa Müller, 1774 (MK919694) and Schistocerca pallens Thunberg, 1815

207 (KM853186).

208

209

210

211

212

213

214

215

216

217

218

219

220

221

222

223

224

\section{Compliance with the International Commission on Zoological Nomenclature}

The electronic version of this article in Portable Document Format (PDF) will represent a published work according to the International Commission on Zoological Nomenclature (ICZN), and hence the new names contained in the electronic version are effectively published under that Code from the electronic edition alone. This published work and the nomenclatural acts it contains have been registered in ZooBank, the online registration system for the ICZN. The ZooBank LSIDs (Life Science Identifiers) can be resolved and the associated information viewed through any standard web browser by appending the LSID to the prefix http://zoobank.org/. The LSID for this publication is: urn:lsid:zoobank.org:pub:27A4D685-9042-40C2-A40A89FF8BCC489B. The online version of this work is archived and available from the following digital repositories: PeerJ, PubMed Central SCIE and CLOCKSS.

\section{Results}

\section{Description of Humbertium covidum}

\section{Taxonomy}

Order Tricladida Lang, 1884 (Lang 1884)

Suborder Continenticola Carranza, Littlewood, Clough, Ruiz-Trillo, Baguña \& Riutort, 1998 (Carranza et al. 1998) 
Family Geoplanidae Stimpson, 1857 (Stimpson 1857)

226

Subfamily Bipaliinae von Graff, 1896 (Von Graff 1896)

227

Genus Humbertium Ogren \& Sluys, 2001 (Ogren \& Sluys 2001)

228

229

Humbertium covidum n. sp.

230

urn:1sid:zoobank.org:act:3847E9FE-463B-4FDB-A164-88765A52D65A

231

232

Synonym: Diversibipalium "black" of Justine et al., 2018

233 Type-locality: Garden in Casier, county of Casier, Province of Treviso, Region of Veneto, Italy.

234 Coordinates: E 12.289391, N 45.639459. Collected by Enrico Ruzzier on 30th September 2019.

235 Type-material: Holotype MNHN JL351B (36 microslides anterior LSS, pre-pharyngeal TS and 236 posterior LSS in a single block) and Paratypes MNHN JL351A (34 microslides TS anterior half 237 and LSS posterior portion in a single block); 14 Paratypes (MNHN JL351C-G and JL351Q-Y) 238 retained whole.

239 Additional material and localities: MNHN JL090, 6 specimens, domestic garden in Saint-Pée240 sur-Nivelle, Department of Pyrénées Atlantiques, France, collected 12 November 2013; MNHN 241 JL343, 1 specimen, domestic garden in Billère, Department of Pyrénées Atlantiques, France, 242 collected 14 May 2019.

243 Behaviour and habitat: In Casier, Italy, the species was the only flatworm found; numerous 244 specimens were swarming, and the species was active in the earliest hours of the morning, not 245 during late evening or at night. The two records from France were from gardens where Bipalium 246 kewense was also found.

247 Molecular information: MNHN JL090 from Saint-Pée-sur-Nivelle: partial cox1 sequence from 248 Sanger sequencing MG655588 (Justine et al. 2018); partial LSU from NGS, MZ520989 (this 249 paper); partial SSU from NGS, MZ520996 (this paper); complete mitogenome MZ561471 (this 250 paper). MNHN JL343 from Billère: partial coxl sequence from Sanger sequencing, MZ622153 251 (this paper). MNHN JL 351 from Casier, partial cox 1 sequence, 5 replicates from Sanger 
252 sequencing MZ622148-MZ622152 (this paper); partial LSU, 3 replicates from Sanger

253 sequencing MZ647546-MZ647548 (this paper); partial LSU from NGS MZ520988 (this paper);

254 partial SSU from NGS MZ520995 (this paper); complete mitogenome MZ561472 (this paper).

255 See Supplemental File 1 for details.

256 Etymology: The specific name covidum was chosen as homage to the numerous casualties

257 worldwide of the COVID-19 pandemic. Furthermore, a large part of this study was written

258 during the lockdowns.

259

260

261

262

263

264

265

266

267

268

269

270

271

272

273

274

275

276

277

278

279

280

281

\section{Similarity of coxl sequences from various populations}

For the specimens from Casier, Italy, we had 6 coxl sequences, including 5 from Sanger sequencing (MNHN JL351H, J, K, L, M) and one from the NGS mitogenome. In addition, we had the coxl sequence of 1 specimen from Billère, Pyrénées Atlantiques (MNHN JL343) and the coxl sequences of 2 specimens MNHN JL090 from Saint-Pée-sur-Nivelle, Pyrénées Atlantiques, mentioned in our 2018 paper (Justine et al. 2018) and described as Diversibipalium sp. "black", one from Sanger sequencing and one from the NGS mitogenome. The ML and NJ trees (Figure 1) built from these 9 sequences, and 1 sequence of $B$. kewense as the outgroup were identical and showed that sequences were separated into two clades: one clade included all sequences from France (both from Billère and Saint-Pée-sur-Nivelle) and all these sequences were identical; one clade included all sequences from Italy and all these sequences were identical. The differences between two clades involved 10 positions out of 387, i.e. the distance based on partial cox 1 sequences was $2.58 \%$.

\section{Diagnosis}

Specimens of Humbertium with reniform-shaped headplate, with dark brown to black dorsal ground colour, without stripes or other ornamentation, ventral surface light grey - greyish brown with paler creeping sole; eyes in a triple row around anterior headplate, present dorso-laterally on headplate, ventrally behind the lappets, continuing along the sides of the body in a staggered row posteriorly; pharynx plicate; testes ventral, extending from behind ovaries to pharynx; vas deferens enter penis bulb separately; penis bulb small, strongly muscularised; penis almost horizontal, elongate, tapered; male atrium almost horizontal then steeply inclined ventrally; female genital canal almost vertical, in two parts with shell glands opening into the proximal canal; ovovitelline ducts ascend dorsally before the gonopore to enter the proximal female 
282 glandular canal antero-dorsally; the male and female efferent ducts are contained within a

283 muscular genital pad through which the female canal opens to the left and slightly dorsal to the

284 male canal, both entering the common genital canal slightly posterior and above the gonopore. A

285 viscid gland is present in the genital pad anterior to the male efferent duct. The efferent canals

286 open into a narrow horizontal highly glandular common genital canal. The common canal opens

287 into the common atrium, in which the gonopore is centrally placed ventrally.

288 Morphology

289 Photographs of specimens are presented for live specimens from Italy (Figures 2-5) and Billère

290 in France (Figures 6-10) and preserved specimens from Saint-Pée-sur-Nivelle (Figures 11-12).

291 Headplate reniform with rounded non-recurved lappets, with width of headplate in living

292 specimens about 1.3 times the maximum body width, and headplate length to width ratio 1:1.6-

2932.7 (measured from scaled drawings of photographs of living specimens, Fig 19 Justine et al

294 2018), and 0.8 times the maximum body width in preserved specimens. Living specimens attain

295 a length of 20-25 mm, and preserved specimens 9-20 $\mathrm{mm}$ in length, with the body width:length

296 ratio 1:4.5-1:5.7. Dorsal ground colour dark brown to black, with no evidence of dorsal stripes

297 or bands on body or headplate (Figures 2, 3, 5, 6). Ventral surface light grey to greyish-brown

298 colour with pale grey creeping sole (Figures 3, 4). Dimensions of preserved sexual specimens

299 are provided in Table 2 and Figures 11-12.

300 Internal anatomy

301 Body wall and musculature

302 These characteristics are shown in Figures 13-14. The epithelium is thicker dorsally (28 $\mu \mathrm{m}-32$

$303 \mu \mathrm{m})$ than ventrally $(12 \mu \mathrm{m}-21 \mu \mathrm{m})$. Three types of rhabdoids are present: large xanthophil

304 chondrocytes measuring $23.8 \times 5.6 \mu \mathrm{m}$ to $30.8 \times 4.2 \mu \mathrm{m}$ (length $\times$ width) predominate over the

305 dorsum to the marginal zone, and xanthophil rhammites measuring $21.0 \times 1.4 \mu \mathrm{m}-25.2 \times 2.8 \mu \mathrm{m}$

306 (length $\times$ width) also cover the same area but are less numerous. Both the chondrocytes and

307 rhammites project slightly above the epithelium. Micro-rhabdites (stäbschen) $2.8-4.2 \mu \mathrm{m} \times 0.7$

$308 \mu \mathrm{m}$ (length $\times$ width) are present in the ventral epithelium, mainly either side of the creeping sole.

309 Of the epidermal secretions, xanthophil secretions predominate over the dorsum to the marginal

310 zone, with erythrophil and cyanophil granular secretions relatively sparse except over the 
311 creeping sole, with a small concentration of erythrophil secretions either side of the slight central

312 protuberance on the creeping sole. Epidermal secretions on the headplate reflected those of the

313 rest of the body. All epidermal secretions are derived from mesenchymal secretory cells. There is

314 no evidence of a glandular margin. Fine black granular pigment is sparsely scattered throughout

315 the dorsal mesenchyme, though it was noted that Sanderson's fluid appeared to elute some black

316 dorsal pigment. The ciliated creeping sole is $21.6 \%-30.8 \%$ of the body width and is slightly

317 protuberant centrally and bears an insunk ciliated epithelium.

318 Cutaneous musculature is tripartite and very weakly developed, comprising circular muscle

319 represented by a single fibre, single decussate diagonal fibres, and longitudinal muscles in small

320 bundles of $2-3$ fibres each, CMI 2-3\%.

321 Parenchymal musculature consists of a strong ventral plate of longitudinal muscles extending

322 laterally to the mid-lateral region and divided into uneven bundles of 4-10 fibres by dorsoventral

323 muscles, with weak supraneural and dorsal parenchymal longitudinal muscles present as single

324 fibres. Strong dorsal transverse muscles and weak supraintestinal and dorsoventral muscles are

325 present. PMI $8.4-15 \%$ of which the dorsal transverse muscles contribute the greater amount.

326 Alimentary system

327 The pharynx is collar-form (Figure 15), with the dorsal insertion in the posterior third of the

328 pharyngeal pouch and posterior to the mouth, and the ventral insertion anterior to the mouth. The

329 outer pharyngeal musculature comprises an ectal single fibre of longitudinal muscle underlain by

330 circular muscles and an ental layer of longitudinal muscles. The inner musculature consists of a

331 single longitudinal muscle fibre underlying the insunk epithelium, underlain by sheaths of

332 circular and longitudinal muscles (derived planariid type). Radial muscles, erythrophil,

333 xanthophil and cyanophil secretory ducts make up the mid-pharyngeal wall. The pharyngeal

334 pouch is $1068-1342 \mu \mathrm{m}$ long, representing $8-10 \%$ of the total body length. The mouth is situated

335 in the approximate mid-ventral region of the pouch. Oesophagus absent.

336 Sensory organs

337 The sensorial zone contours the anterolateral sub-margin of the headplate and consists of flat

338 tooth-like aciliate papillae about $55 \mu \mathrm{m}$ high and $38 \mu \mathrm{m}$ wide separated from each other by a 
339 groove of $10 \mu \mathrm{m}$, with about 20 papillae per millimetre. Ciliated pits about $20 \mu \mathrm{m}$ deep and $4 \mu \mathrm{m}$

340 wide open just below the lips of the papillae.

341 Eyes are present as a triple row contouring the anterior margin of the headplate, with extension

342 dorso-laterally, and ventrally behind the lappets, then continuing posteriorly along the body sides

343 in a staggered row (Figure 16). The eyes are pigment cup ocelli of similar shape and size, about

$34416 \mu \mathrm{m}$ in diameter, with two retinal clubs per ocellus.

345 Reproductive organs

346 The ovaries are spheroidal, $150 \mu \mathrm{m}$ in diameter, located almost a millimetre behind the anterior

347 margin of the headplate and are half embedded in the ventral nerve cords.

348 The testes are ventral, round to ovoid in shape about $300 \mu \mathrm{m}$ high and $220 \mu \mathrm{m}$ in diameter and

349 extend uniserially from behind the ovaries posteriorly to the pharynx. They open towards the

350 lower testicular pole via short sperm ductules into the vasa deferentia. The vasa deferentia of

351 both sectioned specimens of Humbertium covidum contained mature spermatozoa. In both

352 specimens, the testes are at different stages of maturity with those nearest the copulatory organs

353 containing mature spermatozoa.

354 The copulatory organs (Figures 17-18) lie 250-590 $\mu \mathrm{m}$ behind the pharyngeal pouch. The male

355 organ rises $20^{\circ}$ dorsad from the horizontal and the male atrium dips steeply $50^{\circ}$ ventrad, with the

356 female organ almost vertically positioned ( $10^{\circ}$ from the vertical towards the posterior).

\section{Male organs}

358 The protrusible penis comprises a small but highly muscular bulb, with an elongate, ventrally

359 curved, and tapered finger-like papilla opening towards the left-hand side, and filling most of the

360 conical male atrium. The lumen of the seminal (prostatic) vesicle is $50-60 \mu \mathrm{m}$ in diameter and

361 lined by a cuboidal secretory epithelium receiving fine granular erythrophil secretions from

362 erythrophil mesenchymal glands surrounding the bulb. This epithelium grades into a tall

363 voluminous nucleate columnar epithelium penetrated by the expanded terminal ducts of

364 mesenchymal erythrophil glands external to the bulb, discharging secretions into the proximal

365 ejaculatory duct. At about the point where the penis bends towards the gonopore, the lining of

366 the ejaculatory duct transitions to a cuboidal epithelium of the distal ejaculatory duct with a 
367 reduction in secretions and height, and from there grades to the flat nucleate-facing epithelium of 368 the distal penis papilla.

369 The dorsal half of male atrium is lined by a low-facing epithelium and the ventral half lined by a

370 low nucleate columnar epithelium that also covers the proximal external penis. Distally the

371 atrium is lined by a low-facing epithelium. An inner strong sheath of circular muscles and an

372 external sheath of longitudinal muscles underlie the atrial epithelium.

373 Musculature of the penis bulb consists of a strong outer sheath of broad bands of longitudinal

374 muscles between which oblique muscles are interwoven. The ejaculatory duct is surrounded by a

375 strong inner layer of circular muscles underlain by mixed longitudinal and circular muscles, with

376 a sheath of circular muscles underlying the outer penial epithelium.

377 The vasa deferentia, lined by a cuboidal epithelium, lie lateral to and on the same level as the

378 ovovitelline ducts, and just below the testes with which they communicate via a short sperm 379 ductule. Passing posteriorly, they continue to the level of the penis bulb where they gently rise, 380 expand to form spermiducal vesicles and recurve, piercing the anteriad penis bulb to separately 381 open into the seminal vesicle.

382 Female organs

383 The glandular canal is aligned almost at right angles to the ventral surface, is about $370 \mu \mathrm{m}$ in 384 length, and is divided into two distinct parts - the proximal (dorsad) section, and the distal

385 (ventrad) section: the proximal two-thirds of the glandular canal is thistle-shaped with a 386 maximum diameter of around $220 \mu \mathrm{m}$, with a distinct constriction before the centrally

387 invaginated flared blind end where the ovovitelline ducts debouche (could be termed the seminal 388 receptacle). The proximal glandular canal is lined by a tall columnar epithelium with basal 389 nuclei. Secretory ducts, from erythrophil (shell-glands) and cyanophil glands in the surrounding 390 mesenchyme, pierce the epithelium to discharge their contents into the lumen. The fine granular 391 secretions from both types of glands condense within the epithelium and are secreted as 392 membrane-bound masses into the glandular canal. The distal third of the glandular canal, lined 393 by a non-secretory ciliated columnar epithelium, narrows to $70 \mu \mathrm{m}$ then tapers to $16 \mu \mathrm{m}$ to 394 discharge into the common genital canal. Underlying the epithelium of the glandular canal is a 
395 layer of circular muscles external to which are longitudinal muscles, the whole being invested in 396 a weak muscularis.

397 The ovovitelline ducts, lined by a ciliated cuboidal epithelium with a circular muscularis, emerge

398 from the lower poles of the ovaries, ascend slightly to pass posteriorly along the lateral margins

399 of the nerve cords. The ovovitelline ducts turn dorsally before the gonopore (holotype JL351B;

400 in the paratype JL351A they turn dorsally about level with the posterior lip of the gonopore some

$401100 \mu \mathrm{m}$ posteriad to that figured for the holotype), rise and enter the female glandular canal

402 antero-dorsally, exhibiting the proflexed condition.

403 Common genital canal and common atrium

404 In the mesenchyme below the male and female organs in the left body wall lies a crescentic band 405 of densely aggregated erythrophil and basiphil glands (Figure 19). Moving from the left to the 406 right through the mesenchyme, a crescentic split develops in the body wall ventral to the 407 glandular mesenchyme that eventually enlarges to become the common atrium (Figure 20). At 408 about the same point, an elongate fissure develops horizontally along the mid-band of the 409 glandular mesenchyme, in what becomes the common genital canal on the dorsal side of the 410 fissure. For about $60 \mu \mathrm{m}$ across the body, the wall of the mesenchyme separates the common 411 genital canal from the common atrium (Figure 21). The common genital canal is lined by a

412 highly glandular insunk epithelium, richly endowed with granular lightly erythrophil secretions 413 that are secreted as packets of erythrophil granules, alternating with cyanophil strand secretions, 414 typical of the secretory elements related to cocoon formation. The common atrium is lined by an 415 insunk columnar epithelium, through which amorphous cyanophil secretions are discharged.

416 Commensurate with the appearance of the gonopore, the mesenchymal wall thins to form a 417 residual flap around what becomes a single common atrium. Numerous erythrophil glands 418 discharge their granular secretions into the crease formed between the residual flap and genital 419 pad.

Genital pad and viscid gland

421 The genital pad comprises strong interwoven circular and oblique muscles covered by the same 422 epithelium as the common genital canal. In the anteriad pad is situated an ovoid-shaped viscid 423 gland (Figures 22-23), $280 \mu \mathrm{m}$ high and 120-200 $\mu \mathrm{m}$ in diameter, with a duct 160-200 $\mu \mathrm{m}$ long 
424 and $20-70 \mu \mathrm{m}$ in diameter that the opens into the common genital canal. The epithelium of the 425 viscid gland is predominantly charged with finely granular cyanophil secretions, alternating with 426 packets of amorphous dark erythrophil secretions both derived from glands in the surrounding 427 mesenchyme. The secretions discharged into the lumen combine to form thin dark basiphil 428 strands.

429 Vitellaria are sparse and lie between diverticula of the gut. A genito-intestinal duct is absent.

430 Additional comments

431 Fixation

432 Stain uptake by the tissue sections of both specimens was suboptimal, in part due to the fixation 433 in $95 \%$ ethanol resulting in pronounced tissue vacuolation, and possibly partly due to the 434 prolonged post-fixation treatment in Sandison's fluid. The control tissue sections included with 435 the slides of Humbertium covidum verified that the Mallory stain worked perfectly on 436 formaldehyde-fixed tissue.

437 Pathology

438 The larva of a nematode was present in the creeping sole of the holotype.

439 Video file

440 A short video file of a living specimen is available as Supplemental File 2.

441 Occurrences

442 The species was recorded in 2013 from a single garden in Saint-Pée-sur-Nivelle (Department of 443 Pyrénées Atlantiques, France) in which B. kewense was also present. According to the owner, the 444 species was present for years in the garden and was still present in 2017. It was then found in a 445 garden in Billère, in the same Department, ca. $100 \mathrm{~km}$ from the first location; this garden was 446 also heavily infested with B. kewense (Justine et al. 2018). Finally, one of us found in 2019 an 447 abundant population in Casier, Province of Treviso, Italy. In 2019, an intensive campaign on 448 Twitter in various European languages asking for additional reports, did not provide any 449 additional information. In the discussion, we report possible other occurrences in various 450 countries. 
451 Description of Diversibipalium mayottensis n. sp.

452 Taxonomy

$453 \quad$ Order Tricladida Lang, 1884 (Lang 1884)

454 Suborder Continenticola Carranza, Littlewood, Clough, Ruiz-Trillo, Baguña \& Riutort, 4551998 (Carranza et al. 1998)

$456 \quad$ Family Geoplanidae Stimpson, 1857 (Stimpson 1857)

457

458

459

460

461

462

Diversibipalium mayottensis n. sp.

urn:Isid:zoobank.org:act:B59FEE8E-70FD-4DEC-B839-554C351701F8

463

464 Synonym: Diversibipalium "blue" of Justine et al., 2018

465 Type-locality: Ouangani, Mayotte.

466 Additional localities: Mtsamboro and Mamoudzou, Mayotte.

467 Type-material: Holotype MNHN JL282, Cascade du Mont Meoni ouaj Coconi, Commune of

468 Ouangani, Mayotte; Coordinates: W 45.12936111, S 12.83522222; Collected on 30 April 2015;

469 Photographed live (Figures 24-27); length of preserved specimen 15mm; coxl sequence

470 MG655598. Paratypes: MNHN JL280, Dziani, Commune of Mtsamboro, Mayotte; Coordinates:

471 W 45.08091667, S 12.71208333, 29 April 2015; 1 specimen, head not visible; length of

472 preserved specimen $7 \mathrm{~mm}$; coxl sequence MG655596. MNHN JL281, Dziani, Commune of

473 Mtsamboro, Mayotte; Coordinates: W 45.08758333, S 12.69638889, 29 April 2015; specimen

474 JL281A, length preserved $15 \mathrm{~mm}$, first slightly damaged for Sanger sequencing, later almost

475 completely destroyed for NGS sequencing (only head retained); JL281B, $5 \mathrm{~mm}$; JL281C, length

476 preserved $9 \mathrm{~mm}$; coxl sequence MG655597 (based on 3 identical replicates). MNHN JL283, 
477 Convalescence, Commune of Mamoudzou, Mayotte; Coordinates: W 45.18963889, S

478 12.76891667, 4 May 2015; 1 specimen, head not visible, preserved $20 \mathrm{~mm}$, alive ca. $30 \mathrm{~mm}$; not

479 sequenced. MNHN JL284, Îlot Mtsamboro, Commune of Mtsamboro, Mayotte; Coordinates: W

480 45.02769444, S 12.64247222, 5 May 2015; 1 specimen, head visible, tail damaged, length

481 preserved $12 \mathrm{~mm}$, coxl sequence MG655599. All specimens collected by Laurent Charles. See

482 also Supplemental File 1.

483 Behaviour and habitat: In Mayotte, all specimens were collected during the day, under dead 484 wood or leaves, as part of a terrestrial mollusc program. No collection was attempted during the 485 night. All localities were in a slightly degraded natural environment, with little human presence.

486 No research was done to know whether the species was found in gardens, but no citizen science 487 record was received that would suggest this is the case.

488 Molecular information: All partial coxl sequences from 6 specimens listed above were identical; 489 see Figure 2 in Justine et al. 2018. One specimen (MNHN JL281A) used for NGS sequencing, 490 providing sequences for SSU (MZ520997), LSU (MZ520986) and complete mitogenome 491 (MZ561470).

492 Etymology: The specific name mayottensis refers to the type-locality.

493 Attribution of the species to Diversibipalium

494 The genus Diversibipalium Kawakatsu et al., 2002 is a collective group created to temporarily 495 accommodate species whose anatomy of the copulatory apparatus is still unknown (Kawakatsu et 496 al. 2002) and it is therefore logical that we attribute the new species to this genus.

\section{Diagnosis}

498 Specimens of Diversibipalium with a rusty-brown coloured club-shaped headplate, with 499 iridescent blue green dorsal ground colour in life, dark brown colour when preserved, with the 500 suggestion of a fine white median dorsal stripe; ventral surface light brown with white to pale 501 green coloured creeping sole. The mouth is present in the anterior second fifth of the body, and 502 gonopore in the fourth body fifth. 
503 Morphology

504 The specimen has the overall morphology of a typical bipaliine, with the headplate of the living

505 specimen is a rusty-brown colour that extends to some irregular patches on the "neck" (Figures

506 24-25). The dorsal ground colour is an iridescent blue green (“dark turquoise glitter") (Figures

507 24-27), with a hint of a fine white median stripe, and the ventral surface a light brown colour,

508 with the creeping sole white to pale green. The iridescence and blue-green colour are lost on

509 fixation, leaving a dark brown ground colour. The posterior margins of the headplate are not

510 recurved but rounded (reniform), giving the headplate a club-shape, with width of headplate in

511 living specimens 1.1-1.3 times the maximum body width, and headplate length to width ratio

512 1:0.6-0.7 (relative dimensions taken from photographs of living specimens in Figures 24-25).

513 The living specimens are up to about $45 \mathrm{~mm}$ in length.

514 A preserved sexual specimen (paratype JL281C), $9 \mathrm{~mm}$ long and $1 \mathrm{~mm}$ wide, had the mouth

515 situated ventrally approximately $3.5 \mathrm{~mm}$ (39\% of the body length) from the anterior end, and

516 gonopore $3 \mathrm{~mm}$ (33\% of the body length) posterior to the mouth. All specimens were used for

517 molecular analysis with the exception of JL 283. In view of the very few specimens available, no

518 specimen was used for histological methods.

\section{Mitochondrial genomes}

520 New mitogenomes for five species

521 The main characteristics of all mitogenomes obtained during this study are summarised in Table

522 3. The genomic maps are also presented for H. covidum JL351 (Figure 28), H. covidum JL090

523 (Figure 29), D. mayottensis JL281 (Figure 30), B. vagum JL307 (Figure 31), B. adventitium

524 JL328 (Figure 32) and D. multilineatum JL177 (Figure 33). We also present the genomic map

525 of B. kewense (Figure 34). With the exception of D. multilineatum JL177, all mitogenomes

526 seemed complete, and all are colinear concerning protein-coding and rRNA genes. The situation

527 with tRNA is slightly different. The number of tRNAs found among the mitogenomes varies

528 between 21 to 22. For example, it was impossible to find a $t R N A-T h r$ for both specimens of $H$.

529 covidum, while it is commonly found in the cluster of tRNA comprised between cob and $r r n L$ in

530 other species such as B. kewense, D. mayottensis or B. vagum. Also, B. adventitium singularizes

531 itself from the others by the total lack of tRNA cluster in the aforementioned area. Instead, two

532 of these tRNAs, $t R N A$-Asn and $t R N A$-Leu were found in an intergenic area between ND5 and 
533 ND6. In a similar situation to that explained below regarding the $16 \mathrm{~S}$ gene, it should be noted

534 that it was often difficult to detect tRNA among these specimens.

535 No putative ATP8 gene could be evidenced so far. Blastx analyses of all mitogenomes from

536 Bipaliinae were done against a customized database that included the putative ATP8 amino-acid

537 sequences of Stenostomum sthenum Borkott, 1970 (ARW59252) and Macrostomum lignano

538 Ladurner, Schärer, Salvenmoser \& Rieger 2005 (ARW59249) from Egger et al. (2017), and also

539 the putative ORF neighbouring the ND2 gene of Girardia sp. (KP090061) and Phagocata

540 gracilis Haldeman, 1840 (KP090060), considered by Ross et al. (2016) as putative highly

541 divergent atp8. All attempts failed to find any ATP8 candidate among the Bipaliinae.

542 Genomic comparison at the population level of $H$. covidum

543 Table 4 lists the protein-coding genes of $H$. covidum, and compares the sequences obtained from

544 JL351 (from Italy) and JL090 (from France). All mitochondrial protein-coding genes were found

545 to display polymorphisms, some of them being non-silent. A gene commonly used for molecular

546 barcoding and phylogeny such as the coxl gene showed 35 polymorphisms on $1551 \mathrm{bp}$, which

547 corresponds to a percentage of difference of $2.25 \%$. This difference is interpreted as

548 intraspecific. As a comparison, coxl alignment between Dugesia japonica Ichikawa \&

549 Kawakatsu, 1964 and D. ryukyuensis Kawakatsu, 1976 showed a much larger difference of

$55017.91 \%$. Similarly, B. kewense showed 16.93\% differences with B. adventitium and 15.7\% with

551 B. vagum. Noticeable differences, which include SNPs and indels, were found in the 16S rRNA

552 genes of the two specimens of $H$. covidum, as described below.

\section{The peculiar case of the $16 \mathrm{~S}$ gene}

554 As more mitogenomes of Bipaliinae have been sequenced, a recurrent issue has arisen.

555 Systematically, tools such as MITOS and MITOS2 were unable to locate the exact position of

556 the $16 \mathrm{~S}$ gene. For example, when submitting the mitogenome of $H$. covidum JL351 to these

557 software programmes, only a $563 \mathrm{bp}$ fragment was recognised, meaning that a large subunit of

558 the ribosome, which is smaller than the small subunit, is itself 726 bp long. To verify the putative

559 position of the $16 \mathrm{~S}$, additional alignments were performed with the reference sequence from

560 Schmidtea mediterranea Benazzi, Baguñà, Ballester, Puccinelli \& Del Papa, 1975 (JX398125),

561 which has the advantage of having been verified by RNAseq (Ross et al. 2016). With such a

562 method, a putative gene of 1063 bp was detected for H. covidum JL351. A similar problem arose 
563 with all other species. An alignment of the 'complete' 16S genes from all Bipaliinae is displayed

564 as a LOGO and shown in Figure 35. The portion that corresponds to the $563 \mathrm{bp}$ fragment

565 suggested by MITOS corresponds to the portion that starts around position 530, which

566 delimitates the beginning of a more conserved portion of the gene. The alignments shown in

567 Figure 36 were obtained from the $16 \mathrm{~S}$ genes of both specimens of $H$. covidum, and show where

568 the polymorphisms and indels occurred. In the most conserved region, the start of which is

569 indicated by a star, 7 polymorphisms were found, while 12 polymorphisms and 2 indels were

570 found in the more variable region. A request on Rfam (Kalvari et al. 2021) was not more

571 successful. When submitted, the 'complete' 16S of $H$. covidum JL351 aligned with a 574 bp

572 portion (out of $958 \mathrm{bp}$ ) of the $16 \mathrm{~S}$ gene of the flatworm Stenostomum cf. simplex AW-2018, with

573 an E-value of $3.4 \mathrm{e}^{-42}$ and an identity of $60.45 \%$.

574 Phylogeny

575 The four phylogenetic trees displayed some variations in their topologies, impacted by the fact

576 that the sampling of species was not identical for each of the phylogenies conducted. LSU was

577 the most documented in this case. In the SSU tree (Figure 37), H. covidum appeared as a sister-

578 group to B. vagum, but with low support at the nodes (44\% bootstrap in ML and 0.50 posterior

579 probability in BI). This clade was, in contrast, strongly separated from the other clade containing

580 B. adventitium, B. kewense, B. nobile, D. multilineatum, and $N$. venosum. In the LSU tree

581 (Figure 38), both H. covidum and B. adventitium were separated from the main clade of

582 Bipaliinae, with a polytomy. The position of $B$. vagum was again the least supported of the tree

583 (40\% ML, $0.72 \mathrm{BI})$, and in this case, it was associated with the main clade. The mitochondrial

584 protein tree (Figure 39) showed the highest support. In this tree, H. covidum was associated with

585 B. adventitium. Bipalium vagum was again distinct from the main clade, but here with 100\%

586 support. Finally, the 3-gene tree (Figure 40) also associated H. covidum with B. adventitium, and

587 both with B. vagum, but with lower ML node supports (65\% and 59\%, respectively), while BI

588 node supports were higher (1.00 and 0.96, respectively).

589 The most noticeable difference between the concatenated trees was the relative position of the

590 Geoplaninae and Rhynchodeminae. In the mitochondrial protein-coding genes tree (Figure 39),

591 Bipaliinae were associated with Rhynchodeminae with a node support of $62 \%$, while

592 Geoplaninae were distinguished from both with a node support of $100 \%$. The 3-gene tree 
593 (Figure 40) associated Bipaliinae and Geoplaninae with node supports of 68\% ML and 1.00 BI, 594 while Rhynchodeminae were distinguished from both with a node support of $68 \% \mathrm{ML}$ and 1.00 595 BI. It must be noted that for the 3-gene phylogeny, the cox 1 partial gene only accounted for ca. $59610 \%$ of the size of the trimmed concatenated sequences, since it had to include the partial genes 597 of $N$. venosum and $B$. nobile, which were consequently shorter than the complete genes retrieved 598 from full mitogenomes. Nonetheless, this difference in topology is intriguing, and would justify 599 further investigations.

600 There was a constant and substantial result displayed by all phylogenies (Figures 37-40), which

601 is the position of $D$. mayottensis, always outside the main clade including all other Bipaliinae, 602 with very high support. In contrast to B. vagum for example, whose position varied depending on 603 the marker, D. mayottensis always appeared as a sister-group and relatively distant from a clade 604 including all available representatives of Humbertium, Bipalium, Novibipalium and

605 Diversibipalium. Diversibipalium mayottensis thus appeared to be the sister-group of all other 606 bipaliines.

607 Alien DNA and prey

608 Positive results for alien DNA were obtained for B. adventitium, B. vagum and both specimens of 609 H. covidum. All results are listed in Table 5, and are available as Supplemental File 3 and 610 discussed below.

611 Gastropod DNA was found among both specimens of H. covidum. Depending on the megablast 612 results, some of these sequences could be linked with known species. Results obtained on $H$. 613 covidum JL090 (from France) suggest that this specimen has been feeding on the garden slug 614 Arion hortensis (A. Férussac, 1819) (Arionidae). There were also traces of DNA possibly 615 originating from Discus rotundatus (O. F. Müller, 1774) (Discidae), a very small species of land 616 snails, although here the megablasts are to be interpreted with more caution regarding their 617 percentage of identity. For $H$. covidum JL351 (from Italy), most of the sequences found suggest 618 that it has been feeding on Cochlicopa lubrica (O. F. Müller, 1774) (Cochlicopidae), another 619 species of small land snail. Among others, a large contig corresponding to a complete, circular 620 mitogenome was found by additional data mining after retrieving its SSU. After trimming and 621 extraction of its cox 1 gene, a megablast query returned 99.24\% identity with MF544766 -

622 Cochlicopa lubrica. For B. adventitium JL328, we found traces of a Lumbricidae. Finally, $B$. 
623 vagum JL307 (from Guadeloupe) had traces of DNA probably originating from Subulina octona 624 (Bruguière, 1789) (Achatinidae) or Subulina striatella (Rang, 1831), two snail species 625 widespread in the Caribbean.

626 Discussion

627 The new species Humbertium covidum

628 Molecular results: cox 1 sequences of specimens from three localities

629 The partial coxl sequences of the three specimens from the two localities in France were

630 identical, suggesting that they belong to the same population. The two localities (Saint-Pée-sur-

631 Nivelle and Billère) are distant by about $100 \mathrm{~km}$. The coxl sequences of all 6 specimens from

632 Italy (a single locality) were identical. The partial $\operatorname{cox} 1$ sequences of the Italian specimens were

633 different from the French specimens by $2.58 \%$. We consider that these differences are

634 intraspecific, and that the same species was involved in both localities (Figure 1). A longer

635 discussion is provided below, based on complete mitogenome sequences.

636 Morphology and systematics

637 The genus Humbertium was erected (Ogren and Sluys 2001) to accommodate species (23 species

638 stated but only 22 listed) with the single apomorphic condition OVD-1 in which the ovovitelline

639 ducts turn dorsally before reaching the gonopore and having an antero-dorsal entrance to the

640 female organ, the proflex condition. Currently, of the 22 species of Humbertium, excluding $H$.

641 covidum, three species (H. ferrugineoideum (Sabussowa, 1925), H. sikori (von Graff, 1899), and

642 H. palnisium (de Beauchamp, 1930)) are uncertain as the OVD-1 character is not clearly shown

643 in figures or mentioned in the text (Ogren and Sluys 2001). Only three species are well

644 described: H. ceres (Moseley, 1875), H. ravenalae (von Graff, 1899), and H. woodworthi (von

645 Graff, 1899), the descriptions of the remainder being too concise, or mostly confined to the

646 external morphology and the anatomy of the copulatory organs.

647 The type-species of Humbertium is Perocephalus ravenalae von Graff, 1899. Externally, $H$.

648 covidum mainly differs from this species with its brown-black to black dorsal ground colour and 649 lacking dorsal stripes (H. ravenalae has a brownish dorsal ground colour with fine paired dark 650 median either side of a pale median stripe that passes onto the black headplate, and fine paired 
651 dark marginal stripes). The length of $H$. ravenalae is some three times that of $H$. covidum, and 652 the body apertures are more posteriorly displaced. The internal anatomy of $H$. ravenalae was 653 described by Mell (Mell 1903; von Graff 1899). Humbertium covidum shares the same 654 pharyngeal musculature and pharynx type as $H$. ravenalae, the general musculature of the 655 copulatory organs, and the near vertical placement of the female glandular canal, though in $H$. 656 ravenalae the proximal female canal tilts anteriad, while in $H$. covidum it tilts slightly posteriad. 657 A viscid gland and common genital canal of the type in $H$. covidum and $H$. ceres are absent in $H$. 658 ravenalae.

659 In the two specimens of Humbertium covidum examined histologically, the ovovitelline ducts 660 turn dorsally before the gonopore (holotype) and at the posterior lip of the gonopore (paratype), 661 rise and enter the female glandular canal antero-dorsally. Despite the slight difference between 662 the two specimens at the point at which the ovovitelline ducts begin to ascend, attributed here to 663 relative differences in maturity, the antero-dorsal entrance of these ducts into the female canal 664 are present in both specimens, and it is considered that they exhibit the OVD-1 condition that 665 characterises species of the genus Humbertium.

666 Within the genus Humbertium, H. covidum is a small species about $20 \mathrm{~mm}$ long, readily 667 differentiated externally from the only other described and considerably larger black species, $H$. 668 ferrugineoideum (Sabussowa, 1925) from Madagascar, which attains a length of 75-80 mm, and 669 is black both dorsally and ventrally (H. covidum is grey to greyish brown ventrally), with a white 670 margin of the anterior headplate that is absent in H. covidum. Internally, the penis and female 671 glandular canal of $H$. ferrugineoideum are both acutely angled ventrad some $20^{\circ}$ from the 672 vertical (the penis bulb is almost horizontal in H. covidum), the glandular canal is not thistle673 shaped as in H. covidum, and there is no viscid gland (present in H. covidum).

674 Externally, plain brown-black to black H. covidum is distinguished from similar small "black" 675 species. These include Diversibipalium piceum (von Graff, 1897 in von Graff, 1899) from 676 central Sulawesi, that is $43 \mathrm{~mm}$ long (preserved) black with blueish stippling dorsally and 677 ventrally with black creeping sole, and well developed lappets on the headplate (H. covidum has 678 a reniform headplate without lappets, without blue stippling and with a pale brownish-grey to 679 grey creeping sole). Similar small "black" species also include D. smithi (von Graff, 1899) from 680 Darjeeling, northern India, $54 \mathrm{~mm}$ long (preserved) with velvety blueish black dorsum with a 
681 touch of dull brown, and yellowish-rusty brown colour ventrally with a deep cream-yellowish 682 creeping sole demarcated with blueish-light green margins (von Graff 1899, Whitehouse 1914)

683 (H. covidum lacks a blueish cast to the dorsal ground colour and has a pale brownish grey to grey 684 creeping sole that is not demarcated as in D. smithi). Two other much larger species with dark 685 brown to black ground colour are D. richtersi (von Graff, 1899) from Madagascar, $94 \mathrm{~mm}$ long 686 (preserved) with a small head with weakly formed lappets, dark brown dorsally and ventrally, 687 grading to a reddish colour under the headplate, and mouth displaced more posteriorly than in $H$. 688 covidum, and D. kirckpatricki from Sri Lanka, $60 \mathrm{~mm}$ long (preserved), dark brown dorsally and 689 ventrally, with a pale creeping sole, but with strongly recurved lappets as in D. falcatum from 690 Sumatra, and mouth displaced more posteriorly than in H. covidum. There is also an alien black 691 molluscivorous Diversibipalium species, some 110+ mm long (living) with rounded lappets and 692 small brownish headplate, and possibly with a black median dorsal stripe, recorded in and around 693 Durban in South Africa (Himansu Baijnath pers.com to LW 2016 and observations \#35482045, 694 \#37914997 and \#61592889 in iNaturalist); the species is considered too large to be H. covidum.

695 The specimens with external morphology nearest to H. covidum are the Diversibipalium sp. 696 "Kumamoto" of Yamamoto (2000) from Japan that is $30 \mathrm{~mm}$ long, dark brown-black in colour 697 with an indistinct dark mid-dorsal stripe (Yamamoto 2000). However, the dorsal aspect of a 698 living specimen of $H$. covidum is indistinguishable in photographs from that of an undescribed 699 species of Diversibipalium from Xiamen, China (see Table 6 for iNaturalist data).

700 Internally, with regard to the anatomy of the copulatory organs, in particular the morphology of

701 the proximal female glandular canal, the unusual common genital canal, and presence of a viscid 702 gland, Humbertium covidum stands closest to Humbertium ceres (Moseley, 1875), originally 703 described from specimens collected in the Royal Botanic Gardens, Peradeniya near Kandy, Sri

704 Lanka (Moseley 1875), with the internal anatomy subsequently described by von Graff (1899).

705 Externally, a preserved specimen of $H$. ceres measures $79 \mathrm{~mm}$ in length, with mouth $52 \mathrm{~mm}$ 706 (65.8\% of body length), and gonopore $64 \mathrm{~mm}$ ( $81 \%$ of body length), both displaced more 707 posteriorly than in $H$. covidum. In addition, the dorsum of $H$. ceres is divisible into five 708 longitudinal stripes, the whole of the dorsal aspect of the planarian is irregularly speckled in 709 black, and the headplate is ornamented in dark and light bands. The ventral surface is 710 characterised by paired slight sub-marginal glandular ridges. 
711 Internally, the copulatory organs of $H$. ceres share with $H$. covidum an unusual development of

712 the genital pad creating a broad, narrow elongate common genital duct. At the anteriad end of the

713 duct in $H$. ceres is what von Graff terms a uterus (von Graff 1899). A similar structure, identified

714 here from its secretions as a viscid gland, is present in the anteriad genital pad at the end of the

715 common genital duct in $H$. covidum; it is highly likely the "uterus" of $H$. ceres is also a viscid

716 gland. The thistle-shaped proximal end of the female glandular canal in H. covidum is similar to

717 the shape of the seminal receptacle at the proximal end of the glandular canal in H. ceres.

718 However, the seminal receptacle in $H$. ceres does not receive shell gland secretions, and the

719 ovovitelline ducts open into the glandular canal below the receptacle. In $H$. covidum, the

720 ovovitelline ducts enter the invaginated dorsal end of the proximal glandular canal that receives

721 shell gland secretions. The major difference between these two species is the anteriorly prolapsed

722 female glandular canal in H. ceres, characteristic of a group of three species in Humbertium: H.

723 ceres, $H$. proserpina and $H$. woodworthi that all exhibit this feature (character FCA-2 (Ogren and

724 Sluys 1998)), absent in H. covidum in which the female glandular canal is almost vertical with a

725 slight posteriad tilt.

726 The viscid gland in H. covidum is characterised by cyanophil secretions and appears analogous

727 to the viscid glands described in species of Rhynchodemini and Caenoplanini (Winsor 1998a;

728 Winsor 1998b). It differs from the musculoglandular organs described by Müller (Müller 1902)

729 in Bipalium graffi and B. bohmigi (Type III of Winsor (Winsor 1998a)) that discharge

730 erythrophil secretions into the common atrium. These musculoglandular organs are situated on

731 the genital bulge and appear analogous to the adenochiren on the atrial flaps of species of

732 Artioposthia in which they have been demonstrated to have a role in cocoon formation (Winsor 733 1998a).

\section{Occurrences in Europe and possible occurrences in Asia}

735 As mentioned above, the species has been found in two widely separated gardens in the

736 Department of Pyrénées-Atlantiques in the South-West of France, and one locality in the

737 Province of Treviso in North-Eastern Italy. However, it is well known that bipaliine species are

738 most numerous in South East Asia and Madagascar (von Graff, 1899); we found in the literature

739 and citizen science databases a few records that might be the same species (Table 6). Most 
740 localities in Asia appear to be on islands or coastal areas, but the database is certainly extremely

741 incomplete.

742 Humbertium covidum is probably a species originating from Asia and is an alien species in

743 Europe. Whether it will become an invasive species needs to be monitored in the future.

\section{The new species Diversibipalium mayottensis}

745 Morphology

746 There are no other bipaliine planarians described with the blue-green iridescent dorsal ground

747 colour observed in D. mayottensis. Similar iridescence, which is lost on fixation, has been

748 observed in various species of Caenoplanini, and is possibly due to tightly packed transparent

749 proteinaceous rhabdoids in the epithelium, acting as a diffraction grating (Winsor, 2003).

750 With regard to the club-shaped headplate and general body shape, D. mayottensis is similar to

751 the general morphology of species of Humbertium. In particular, D. mayottensis shares the

752 relative positions of the body apertures with the mouth present in the anterior second fifth of the

753 body, and gonopore in the fourth body fifth, with two species: H. woodworthi (von Graff, 1899)

754 with four dark dorsal stripes, from Madagascar, and H. subboreale (Sabussowa, 1925) a small

755 dark brown species from China.

\section{Molecular characteristics}

757 In 2018 we wrote: "The COI barcode of this specimen is clearly different from all other known

758 sequences. We can safely claim that this species has never been sequenced before" (Justine et al

759 2018). Our current results on the complete mitogenome confirm that the species is distinct from

760 all other species for which the mitogenome is known; in addition, D. mayottensis was sister-

761 group to all other bipaliines in all our phylogenetic analyses. This is probably more significant

762 than the superficial morphological resemblance with various Humbertium species mentioned

763 above.

\section{Possible origin of the species}

765 Because of the proximity of Mayotte with Madagascar, it may be hypothesized that the origin of

766 the species is Madagascar, not Asia as for most Bipaliinae. 
767 Mitogenomes

768 Including B. kewense (Gastineau et al., 2019), there are now up to 6 species of Bipaliinae for

769 which mitogenomes have been sequenced. For some of them, there were a few protein-coding

770 genes for which it was not possible to find either start or stop codons. There are already several

771 reports among Platyhelminthes of mitochondrial protein-coding genes for which no start codon

772 could be found (Justine et al. 2020a; Ross et al. 2016; Sakai \& Sakaizumi 2012; Solà et al. 2015).

773 In the case of $H$. covidum, the $N D 3$ gene is supposed to have a premature stop, by addition at the

7743 ' extremity of two A after a T, immediately followed by the $t R N A$-Ala. No stop codon or

775 premature stop could be found at all for the cob gene of $B$. adventitium JL328, for reasons that

776 remain unknown. Excluding D. multilineatum because of its incompleteness, it is possible to say

777 that most of these species have mitogenomes of a size similar to B. kewense (ca. $15500 \mathrm{bp}$ ), with

778 D. mayottensis being slightly longer (15989 bp). The main exception is $B$. vagum, whose

779 mitogenome is 17149 bp long. Bipalium vagum also had the highest number of alternative start

780 codons, with 4 protein-coding genes concerned (cox3, atp6, ND1, ND4L). This extra-length

781 seems to be explained by large intergenic sections located between the $16 \mathrm{~S}$ and cob genes, where

782 the three conserved tRNA ( $t R N A-L e u, t R N A-T h r$, and $t R N A-A s n)$ are separated from each other

783 by hundreds of base pairs. We could not circularise the mitogenome of $D$. multilineatum, even

784 after several iterations of Consed's 'addSolexaReads' function. This suggests that this lacking

785 region consists of repeated sequences that short-read sequencing technologies fail to reveal. We

786 underline the fact that this missing part is located at the very same position as the extra length in

787 B. vagum's mitogenome.

788 We would also like to indicate that recent investigations on parasitic flatworms such as

789 Echinococcus granulosus Batsch, 1786, Clonorchis sinensis Loos, 1907 and Schistosoma

790 haematobium (Bilharz, 1852) using long-read technologies have shown considerable extra-

791 lengths within these mitogenomes, as much as $18.5 \mathrm{~kb}$ long (Kinkar et al. 2021; Kinkar et al.

792 2019; Kinkar et al. 2020). We tend to think that in the near future, long-read technologies might

793 unveil similar features among Geoplanidae.

794 Alien DNA and diet

795 Our results on alien DNA suggest that $H$. covidum feeds on slugs and snails, with a very clear

796 result concerning Cochlicopa lubrica in Italy; this is the only information currently available 
797 concerning the diet of this new species. The information was based on a small number of

798 specimens and should be confirmed by additional experiments. Results on B. adventitium (from

799 Canada) suggest that the specimen fed on a lumbricid earthworm, a result compatible with other

800 information on the diet of the species (Ducey et al. 1999). For B. vagum JL307 from

801 Guadeloupe, results suggest that the specimen fed on a species of Subulina, a small snail; the 802 species is known to feed on snails (Ducey et al. 2007). Interestingly, similar studies on Amaga

803 expatria, an alien geoplanid found in Martinique, another island in the Caribbean, also found that

804 it fed on species of Subulina (Justine et al. 2020a); species of Subulina are widespread in the

805 Caribbean (Delannoye et al. 2015).

\section{A distinct genus for Diversibipalium mayottensis?}

807 All phylogenies showed D. mayottensis as a sister-group to all other Bipaliinae, thus confirming

808 its appurtenance to the subfamily, but making it impossible to assign it to any of the known

809 genera of bipaliines. The subfamily currently includes four genera, namely Bipalium,

810 Humbertium, Novibipalium Kawakatsu et al., 1998 and the collective genus Diversibipalium.

811 External morphology superficially suggests that the species is close to Humbertium, but the

812 reproductive anatomy is unknown. Its position as sister-group to all other bipaliines suggests that

813 a new genus should be described to accommodate $D$. mayottensis. We refrain from doing so here

814 in the absence of anatomical information.

\section{Conclusion}

816 In this paper, we formally described two species of bipaliine geoplanids, previously only known

817 as unnamed species included in the collective genus Diversibipalium. For the first species,

818 Humbertium covidum n. sp., we subsequently obtained fresh specimens collected in Italy and

819 could fully describe the anatomy, based on histological methods. This was not possible for the

820 second species, found only on Mayotte, which is described here as Diversibipalium mayottensis

821 n. sp. on the basis of external morphology. We newly characterised the complete mitochondrial

822 genome of five species of bipaliine geoplanids, including the two new species and $B$.

823 adventitium, B. vagum and D. multilineatum. Based on phylogenetic analyses of the SSU, LSU,

824 mitochondrial proteins and concatenated cox1-SSU-LSU, we built phylogenies of bipaliines for

825 which these sequences are available (6 species). In all phylogenies, D. mayottensis was the 
826 sister-group of all other bipaliines, suggesting that it represents a distinct genus, which needs

827 formal description; this will await availability of additional specimens. Furthermore, we

828 demonstrated that next generation sequencing methods provide an excellent tool for delineating

829 and describing species of geoplanids, since they allow access to both traditionally used

830 sequences (SSU, LSU and coxl) and complete mitochondrial genomes which provide

831 considerable additional information.

\section{Acknowledgements}

833 We thank the colleagues and people who provided specimens, especially Mathieu Coulis,

834 Mathieu Théry, Geneviève Rolland-Martinez and Dino Carraro. We emphasize that lockdowns

835 and social distancing helped us to concentrate on completion of this paper, but we will not forget

836 that the pandemic has affected and still affects the world terribly - the Latin epithet covidum for

837 our new species should thus be considered a homage to the victims of the COVID-19 pandemic.

838 


\section{Abbreviations used in figures of histology}

840 af atrial flap

841 ca common atrium

842 cc copulatory canal

843 cge common genital canal

844 ch chondrocytes

$845 \mathrm{clm}$ cutaneous longitudinal muscles

$846 \mathrm{~cm}$ cutaneous musculature

847 cs ciliated creeping sole

848 dfg distal female glandular canal (= vagina)

849 dip dorsal insertion of pharynx

$850 \mathrm{dtm}$ dorsal transverse muscles

851 ed ejaculatory duct

852 eg erythrophil glands

853 pfg proximal female glandular canal

$854 \mathrm{~g}$ gonopore

855 gm glandular mesenchyme

856 gp genital pad

857 i intestine

858 ma male atrium

$859 \mathrm{~m}$ mouth

860 nc nerve cord 
861 ovd ovovitelline duct

$862 \mathrm{pb}$ penis bulb - penis

863 pg penial glands

864 ph pharynx

865 php pharyngeal pouch

866 pp penis papilla

867 sd spermiducal vesicle

868 sg shell glands

869 sr seminal receptacle

870 sv seminal vesicle

871 te testis

872 tm transverse parenchymal muscle

873 vd vas deferens

874 vg viscid gland

875 vi vitellaria

876 vip ventral insertion of pharynx

877 vp ventral muscle plate

878 


\section{References}

880 Abascal F, Posada D, and Zardoya R. 2007. MtArt: a new model of amino acid replacement for $881 \quad$ Arthropoda. Molecular Biology and Evolution 24:1-5.

882 Andújar C, Creedy TJ, Arribas P, López H, Salces-Castellano A, Pérez-Delgado AJ, Vogler AP 883 and Emerson BC. 2021. Validated removal of nuclear pseudogenes and sequencing artefacts from mitochondrial metabarcode data. Molecular Ecology Resources, 21:1772-

886

Bankevich A, Nurk S, Antipov D, Gurevich AA, Dvorkin M, Kulikov AS, Lesin VM, Nikolenko SI, Pham S, and Prjibelski AD. 2012. SPAdes: a new genome assembly algorithm and its applications to single-cell sequencing. Journal of Computational Biology 19:455-477.

Bernt M, Donath A, Jühling F, Externbrink F, Florentz C, Fritzsch G, Pütz J, Middendorf M, and Stadler PF. 2013. MITOS: improved de novo metazoan mitochondrial genome annotation. Molecular Phylogenetics and Evolution 69:313-319.

Boratyn GM, Schäffer AA, Agarwala R, Altschul SF, Lipman DJ and Madden TL. 2012. Domain enhanced lookup time accelerated BLAST. Biology Direct, 7, 12.

Buhay JE. 2009. "COI-like” sequences are becoming problematic in molecular systematic and 895 DNA barcoding studies, Journal of Crustacean Biology, 29: 96-110. alignment trimming in large-scale phylogenetic analyses. Bioinformatics 25:1972-1973. (Platyhelminthes: Geoplanidae) flatworm spreading across Europe. Zoological Journal of the Linnean Society 177:5-28.

901 Carranza S, Littlewood DTJ, Clough KA, Ruiz-Trillo I, Baguña J, and Riutort M. 1998. A robust molecular phylogeny of the Tricladida (Platyhelminthes: Seriata) with a discussion on

903 morphological synapomorphies. Proceedings of the Royal Society of London B 265:631640. 
905 Crooks GE, Hon G, Chandonia J-M, and Brenner SE. 2004. WebLogo: a sequence logo 906 generator. Genome research 14:1188-1190.

907 Darriba D, Taboada GL, Doallo R, Posada D. 2012. jModelTest 2: more models, new heuristics $908 \quad$ and parallel computing. Nature Methods 9:772.

909 Delannoye R, Charles L, Pointier J-P, and Massemin D. 2015. Mollusques continentaux de la $910 \quad$ Martinique: Muséum national d'Histoire naturelle.

911 Ducey PK, McCormick M, and Davidson E. 2007. Natural history observations on Bipalium cf. 912 vagum Jones and Sterrer (Platyhelminthes: Tricladida), a terrestrial broadhead planarian 913 new to North America. Southeastern Naturalist 6:449-461.

914 Ducey PK, Messere M, Lapoint K, and Noce S. 1999. Lumbricid prey and potential 915 herpetofaunal predators of the invading terrestrial flatworm Bipalium adventitium 916 (Turbellaria: Tricladida: Terricola). American Midland Naturalist 141:305-314.

917 Ducey PK, West L-J, Shaw G, and De Lisle J. 2005. Reproductive ecology and evolution in the 918 invasive terrestrial planarian Bipalium adventitium across North America. Pedobiologia $919 \quad 49: 367-377$.

920 Egger B, Bachmann L and Fromm B. 2017. Atp8 is in the ground pattern of flatworm 921 mitochondrial genomes. BMC Genomics 18:414.

922 Froehlich EM. 1955. Sôbre espécies brasileiras do gênero Geoplana. Boletim da Faculdade de 923 Filosofia, Ciências e Letras da Universidade de São Paulo, Série Zoologia 19:289-339.

924 Gastineau R, and Justine J-L. 2020. Complete mitogenome of the invasive land flatworm 925 Parakontikia ventrolineata, the second Geoplanidae (Platyhelminthes) to display an 926 unusually long cox2 gene. Mitochondrial DNA Part B 5:2115-2116.

927 Gastineau R, Justine J-L, Lemieux C, Turmel M, and Witkowski A. 2019. Complete 928 mitogenome of the giant invasive hammerhead flatworm Bipalium kewense. Mitochondrial 929 DNA Part B 4:1343-1344. 
930 Gastineau R, Lemieux C, Turmel M, and Justine J-L. 2020. Complete mitogenome of the 931 invasive land flatworm Platydemus manokwari. Mitochondrial DNA Part B 5:1689-1690.

932 Glez-Peña, D., Gómez-Blanco, D., Reboiro-Jato, M., Fdez-Riverola, F., \& Posada, D. (2010).

933

934

935

936

937

938

939

940

941

942

943

944

945

946

947

948

949

950

951

952

953
ALTER: program-oriented conversion of DNA and protein alignments. Nucleic Acids Research, 38 (Web Server issue):W14-W18.

Gordon D, Abajian C, and Green P. 1998. Consed: a graphical tool for sequence finishing. Genome research 8:195-202.

Graham NR, Gillespie RG and Krehenwinkel H. 2021, Towards eradicating the nuisance of numts and noise in molecular biodiversity assessment. Molecular Ecology Resources 21:1755-1758.

Hasegawa M., Kishino H., and Yano T. (1985). Dating the human-ape split by a molecular clock of mitochondrial DNA. Journal of Molecular Evolution 22:160-174.

Hazkani-Covo E, Zeller RM, and Martin W. 2010. Molecular poltergeists: mitochondrial DNA copies (numts) in sequenced nuclear genomes. PLoS Genetics, 6(2):e1000834.

Hlaing T, Tun-Lin W, Somboon P, Socheat D, Setha T, Min S, Chang MS and Walton, C. 2009. Mitochondrial pseudogenes in the nuclear genome of Aedes aegypti mosquitoes: implications for past and future population genetic studies. BMC Genetics, 10:11.

Hyman LH. 1943. Endemic and exotic land planarians in the United States: with a discussion of necessary changes of names in the Rhynchodemidae. American Museum Novitates:1-21.

Jones HD, and Sterrer W. 2005. Terrestrial planarians (Platyhelminthes, with three new species) and nemertines of Bermuda. Zootaxa 1001:31-58.

Justine J-L, Gey D, Thévenot J, Gastineau R, and Jones HD. 2020a. The land flatworm Amaga expatria (Geoplanidae) in Guadeloupe and Martinique: new reports and molecular characterization including complete mitogenome. PeerJ 8:e10098. 
954 Justine J-L, Gey D, Thévenot J, Gouraud C, and Winsor L. 2020b. First report in France of

955

956

957

958

959

960

961

962

963

964

965

966

967

968

969

970

971

972

973

974

975

976

977

978

979

980

Caenoplana decolorata, a recently described species of alien terrestrial flatworm (Platyhelminthes, Geoplanidae). bioRxiv:2020.2011.2006.371385.

Justine J-L, Gey D, Vasseur J, Thévenot J, Coulis M, and Winsor L. 2021. Presence of the invasive land flatworm Platydemus manokwari (Platyhelminthes, Geoplanidae) in Guadeloupe, Martinique and Saint Martin (French West Indies). Zootaxa 4951:381-390.

Justine J-L, Théry T, Gey D, and Winsor L. 2019. First record of the invasive land flatworm Bipalium adventitium (Platyhelminthes, Geoplanidae) in Canada. Zootaxa 4656:591-595.

Justine J-L, Thévenot J, and Winsor L. 2014a. Les sept plathelminthes invasifs introduits en France. Phytoma:28-32.

Justine J-L, Winsor L, Barrière P, Fanai C, Gey D, Han AWK, La Quay-Velazquez G, Lee BPYH, Lefevre J-M, Meyer J-Y, Philippart D, Robinson DG, Thévenot J, and Tsatsia F. 2015. The invasive land planarian Platydemus manokwari (Platyhelminthes, Geoplanidae): records from six new localities, including the first in the USA. PeerJ 3:e1037.

Justine J-L, Winsor L, Gey D, Gros P, and Thévenot J. 2014b. The invasive New Guinea flatworm Platydemus manokwari in France, the first record for Europe: time for action is now. PeerJ 2:e297.

Justine J-L, Winsor L, Gey D, Gros P, and Thévenot J. 2018. Giant worms chez moi! Hammerhead flatworms (Platyhelminthes, Geoplanidae, Bipalium spp., Diversibipalium spp.) in metropolitan France and overseas French territories. PeerJ 6:e4672.

Justine J-L, Winsor L, Gey D, Gros P, and Thévenot J. 2020c. Obama chez moi! The invasion of metropolitan France by the land planarian Obama nungara (Platyhelminthes, Geoplanidae). PeerJ 8:e8385.

Kalvari I, Nawrocki EP, Ontiveros-Palacios N, Argasinska J, Lamkiewicz K, Marz M, GriffithsJones S, Toffano-Nioche C, Gautheret D, and Weinberg Z. 2021. Rfam 14: expanded coverage of metagenomic, viral and microRNA families. Nucleic Acids Research 49:D192D200.

Peer] reviewing PDF | (2021:08:64610:2:0:NEW 9 Dec 2021) 
981 Katoh K, and Standley DM. 2013. MAFFT multiple sequence alignment software version 7: improvements in performance and usability. Molecular Biology and Evolution 30:772-780.

983

984

985

986

987

988

989

990

991

992

993

994

995

996

997

998

999

1000

1001

1002

1003

1004

1005

1006

Kawakatsu M, Ogren RE, Froehlich EM, and Sasaki G-Y. 2002. Additions and corrections of the previous land planarian indices of the world (Turbellaria, Seriata, Tricladida, Terricola). Bulletin of the Fuji Women's College (Series 2) 40:157-177.

Kawakatsu M, Sluys R, and Ogren RE. 2005. Seven new species of land planarian from Japan and China (Platyhelminthes, Tricladida, Bipaliidae), with a morphological review of all Japanese bipaliids and a biogeographic overview of Far Eastern species. Belgian Journal of Zoology 135:53-77.

Kinkar L, Gasser RB, Webster BL, Rollinson D, Littlewood DTJ, Chang BCH, Stroehlein AJ, Korhonen PK, and Young ND. 2021. Nanopore sequencing resolves elusive long tandemrepeat regions in mitochondrial genomes. International Journal of Molecular Sciences 22:1811.

Kinkar L, Korhonen PK, Cai H, Gauci CG, Lightowlers MW, Saarma U, Jenkins DJ, Li J, Li J, and Young ND. 2019. Long-read sequencing reveals a $4.4 \mathrm{~kb}$ tandem repeat region in the mitogenome of Echinococcus granulosus (sensu stricto) genotype G1. Parasites \& Vectors 12:1-7.

Kinkar L, Young ND, Sohn W-M, Stroehlein AJ, Korhonen PK, and Gasser RB. 2020. First record of a tandem-repeat region within the mitochondrial genome of Clonorchis sinensis using a long-read sequencing approach. PLOS Neglected Tropical Diseases 14:e0008552.

Kumar S, Stecher G, and Tamura K. 2016. MEGA7: Molecular Evolutionary Genetics Analysis version 7.0 for bigger datasets. Molecular Biology and Evolution 33:1870-1874.

Lago-Barcia D, Fernández-Álvarez FA, Negrete L, Brusa F, Damborenea C, Grande C, and Noreña C. 2015. Morphology and DNA barcodes reveal the presence of the non-native land planarian Obama marmorata (Platyhelminthes: Geoplanidae) in Europe. Invertebrate Systematics 29:12-22. 
1007 Lang A. 1884. Die polycladen (seeplanarien) des golfes von neapel und der angrenzenden 1008 meeresabschnitte: eine monographie: Engelmann.

1009 Laslett D. and Canbäck B. 2008. ARWEN, a program to detect tRNA genes in metazoan 1010 mitochondrial nucleotide sequences. Bioinformatics 24:172-175.

1011 Leite LA. 2012. Mitochondrial pseudogenes in insect DNA barcoding: differing points of view 1012 on the same issue. Biota Neotropica 12:301-308.

1013 Lohse M, Drechsel O, Kahlau S, and Bock R. 2013. OrganellarGenomeDRAW—a suite of tools 1014 for generating physical maps of plastid and mitochondrial genomes and visualizing 1015 expression data sets. Nucleic Acids Research 41:W575-W581.

1016 Makino N, and Shirasawa Y. 1983. Morphological and ecological comparison with two new 1017 species of elongated slender land planarians have several stripes and their new scientific 1018 names. Bulletin of Tokyo Medical College 9:69-83 [In Japanese, English summary].

1019 Makino N, and Shirasawa Y. 1986. Biology of long slender land planarians (Turbellaria) in 1020 Tokyo and environs. Hydrobiologia 132:229-232.

1021 Mateos E, Jones HD, Riutort M, and Álvarez-Presas M. 2020. A new species of alien terrestrial 1022 planarian in Spain: Caenoplana decolorata. PeerJ 8:e10013.

1023

Mell C. 1903. Die Landplanarien der Madagassischen Subregion. Abhandlungen der Senckenbergischen Naturforschenden Gesellschaft 239:193-236.

Meyer-Rochow VB, and Miinalainen I. 2020. Squid sucker teeth and cocoons of a terrestrial flatworm: amino acid content of two nano-structurally identical tissues in phylogenetically unrelated taxa. Zoology 140:125798. Melone B, and Mazza G. 2021. Opening Pandora's box: the invasion of alien flatworms in Italy. Biological Invasions:submitted. 
1031 Moseley HN. 18754. V. On the anatomy and histology of the land-planarians of Ceylon, with 1032 some account of their habits, and a description of two new species, and with notes on the 1033 anatomy of some European aquatic species. Philosophical Transactions of the Royal 1034 Society 164:105-171.

1035 Moseley HN. 1878. Description of a new species of land-planarian from the hothouses at Kew Gardens. Annals and Magazine of Natural History 1:237-239.

Müller J. 1902. Ein Beitrag zur Kenntnis der Bipaliiden. Zeitschrift für wissenschaftliche Zoologie 73:75-114.

Nicholas KB, Nicholas Jr HB, and Deerfield II DW. 1997. GeneDoc: analysis and visualization of genetic variation. embnet news 4:14.

Ogren RE, and Sheldon JK. 1991. Ecological observations on the land planarian Bipalium pennsylvanicum Ogren, with references to phenology, reproduction, growth rate and food niche. Journal of the Pennsylvania Academy of Science 65:3-9.

Ogren RE, and Sluys R. 1998. Selected characters of the copulatory organs in the land planarian family Bipaliidae and their taxonomic significance (Tricladida: Terricola). Hydrobiologia 383:77-82.

Ogren RE, and Sluys R. 2001. The genus Humbertium gen. nov., a new taxon of the land planarian family Bipaliidae (Tricladida, Terricola). Belgian Journal of Zoology 131:201204.

Ogren RE. 1987. Description of a new three-lined land planarian of the genus Bipalium (Turbellaria: Tricladida) from Pennsylvania, USA. Transactions of the American Microscopical Society 106:21-30.

1053

1054

1055

1056

1057
Prozorova LA, and Ternovenko VA. 2018. Редкие и новые виды организмов Дальневосточного морского заповедника. 2. Наземные планарии (Platyhelminthes: Tricladida: Continenticola) [Rare and new species from the Far Eastern Marine Reserve. 2. Land Planarians (Platyhelminthes: Tricladida: Continenticola)] Biota and Environment 3:54-59. 
1058 Prozorova LA. 2021. Новые находки молотоголовых планарий (Platyhelminthes: Tricladida:

1059 Continenticola: Bipaliinae) на российском Дальнем Востоке [New findings of

1060 hammerhead planarians (Platyhelminthes: Tricladida: Continenticola: Bipaliinae) on the

1061 Russian Far East]. Biota and Environment of Natural Areas:55-64.

1062 Ronquist F, Teslenko M, van der Mark P, Ayres DL, Darling A, Höhna S, Larget B, Liu L, 1063 Suchard MA and Huelsenbeck, JP 2012. MrBayes 3.2: efficient Bayesian phylogenetic 1064 inference and model choice across a large model space. Systematic Biology, 61:539-542.

1065 Ross E, Blair D, Guerrero-Hernández C, and Alvarado AS. 2016. Comparative and 1066 transcriptome analyses uncover key aspects of coding-and long noncoding RNAs in 1067 flatworm mitochondrial genomes. G3: Genes, Genomes, Genetics 6:1191-1200.

1068 Sabussowa Z. 1925. Drei neue Arten von Landplanarien. Zoologische Jahrbücher (Systematik) 1069 50:283-298.

1070

1071

1072

1073

1074

1075

1076

1077

1078

1079

1080

1081

1082

1083

Sakai M, and Sakaizumi M. 2012. The complete mitochondrial genome of Dugesia japonica (Platyhelminthes; order Tricladida). Zoological science 29:672-680.

Solà E, Álvarez-Presas M, Frías-López C, Littlewood DTJ, Rozas J, and Riutort M. 2015. Evolutionary analysis of mitogenomes from parasitic and free-living flatworms. PLoS ONE 10:e0120081.

Song H, Buhay JE, Whiting MF and Crandall KA. 2008. Many species in one: DNA barcoding overestimates the number of species when nuclear mitochondrial pseudogenes are coamplified. Proceedings of the National Academy of Sciences of the United States of America, 105:13468-13491.

Stamatakis A. 2014. RAxML version 8: a tool for phylogenetic analysis and post-analysis of large phylogenies. Bioinformatics 30:1312-1313.

Stimpson W. 1857. Prodromus descriptionis animalium evertebratorum, quae in expeditione ad oceanum Pacificum Septentrionalem, Johanne Rogers duce a Republica Federata missa. Proceedings of the Academy of Natural Sciences of Philadelphia offprint. 
1084 Vonvon Graff L. 1896. Über das System und die geographische Verbreitung der Landplanarien. 1085 Verhandlungen Deutsche Zoologische Gesellschaft 6:75-93.

1086 von Graff L. 1899. Monographie der Turbellarien. II. Tricladida, Terricola (Landplanarien). 1087 Leipzig: Englemann.

1088 Whitehouse RH. 1914. Land planarians. In: Zoological records of the Arbor Expedition 191110891912 Part 3 No. 22. Records of the Indian Museum 8: 455-464.

1090 Winsor L, and Sluys R. 2018. Basic histological techniques for planarians. In: Rink JC, ed. 1091 Planarian regeneration Methods in Molecular Biology, vol 1774. New York, NY: Humana 1092 Press, 285-351.

1093 Winsor L. 1983. A revision of the Cosmopolitan land planarian Bipalium kewense Moseley, 10941878 (Turbellaria: Tricladida: Terricola). Zoological Journal of the Linnean Society 79:61$1095 \quad 100$.

1096 Winsor L. 1998a. Aspects of the taxonomy and functional histology in terrestrial flatworms 1097 (Tricladida: Terricola). Pedobiologia 42:412-432.

1098 Winsor L. 1998b. The role of the atrial diverticulum in the copulatory apparatus of the terrestrial 1099 flatworm Platydemus manokwari de Beauchamp (Tricladida: Terricola). Hydrobiologia $1100 \quad 383: 83-89$.

1101 Yamamoto K. 2000. Bipalium sp. Kumamoto - 1. Junshin Chûgakkô - Junshin Joshi Kôtôgakkô 1102 Kiyô 27:39-41 (In Japanese). 


\section{Figure 1}

Humbertium covidum n. sp. from two populations, tree based on cox1 sequences.

The evolutionary history was inferred using the Maximum Likelihood and the NeighbourJoining methods; there was a total of 387 positions in the final dataset. All partial cox1 sequences from Italy (6 specimens) were identical, as were the 3 sequences from France, from two localities. Sequences from France and Italy differed by $2.58 \%$. Bootstrap values: above branches, ML; below branches, NJ.

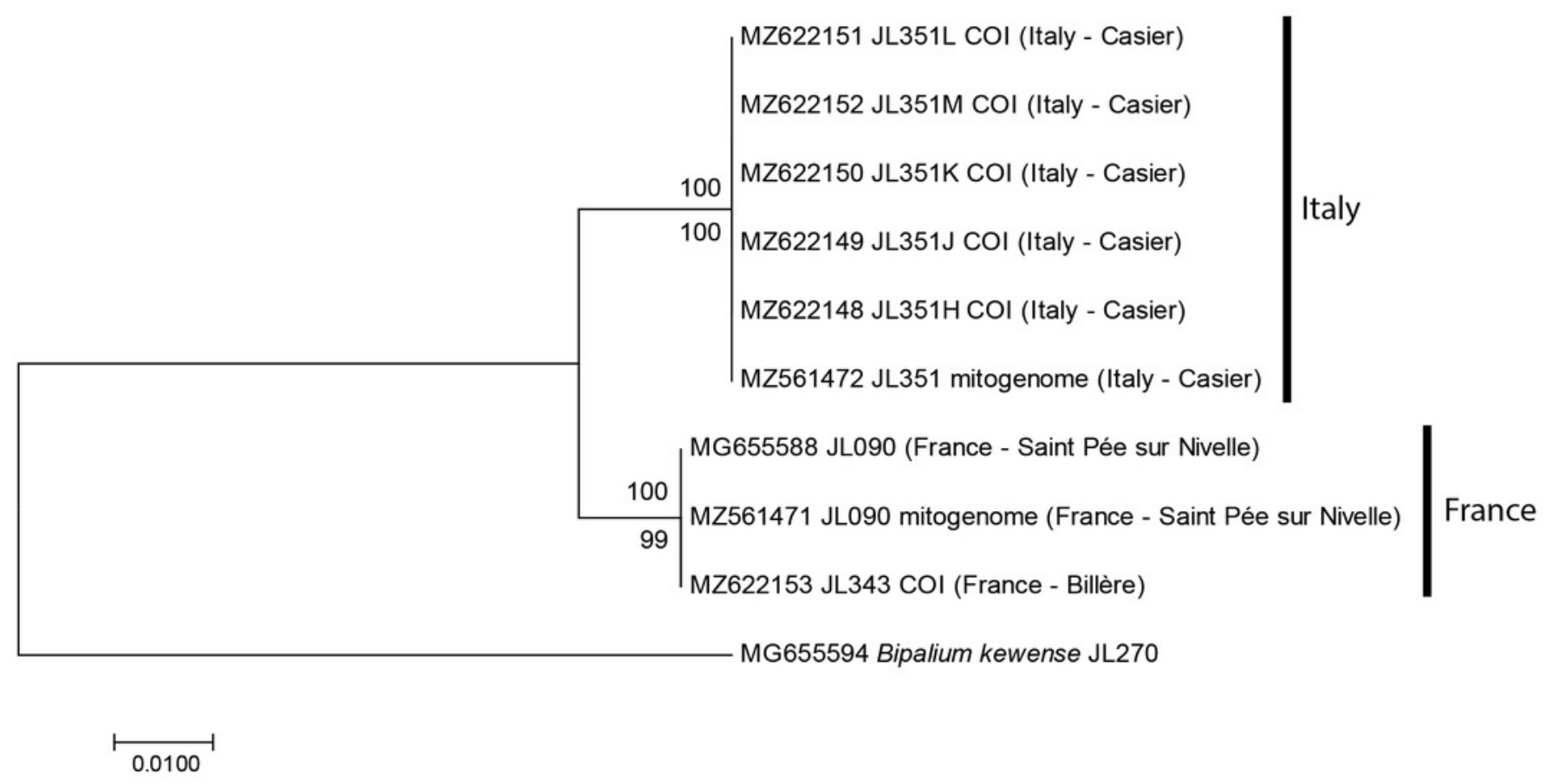


Figure 2

Humbertium covidum n. sp. from Italy, alive.

General dorsal aspect. Photo by Pierre Gros.

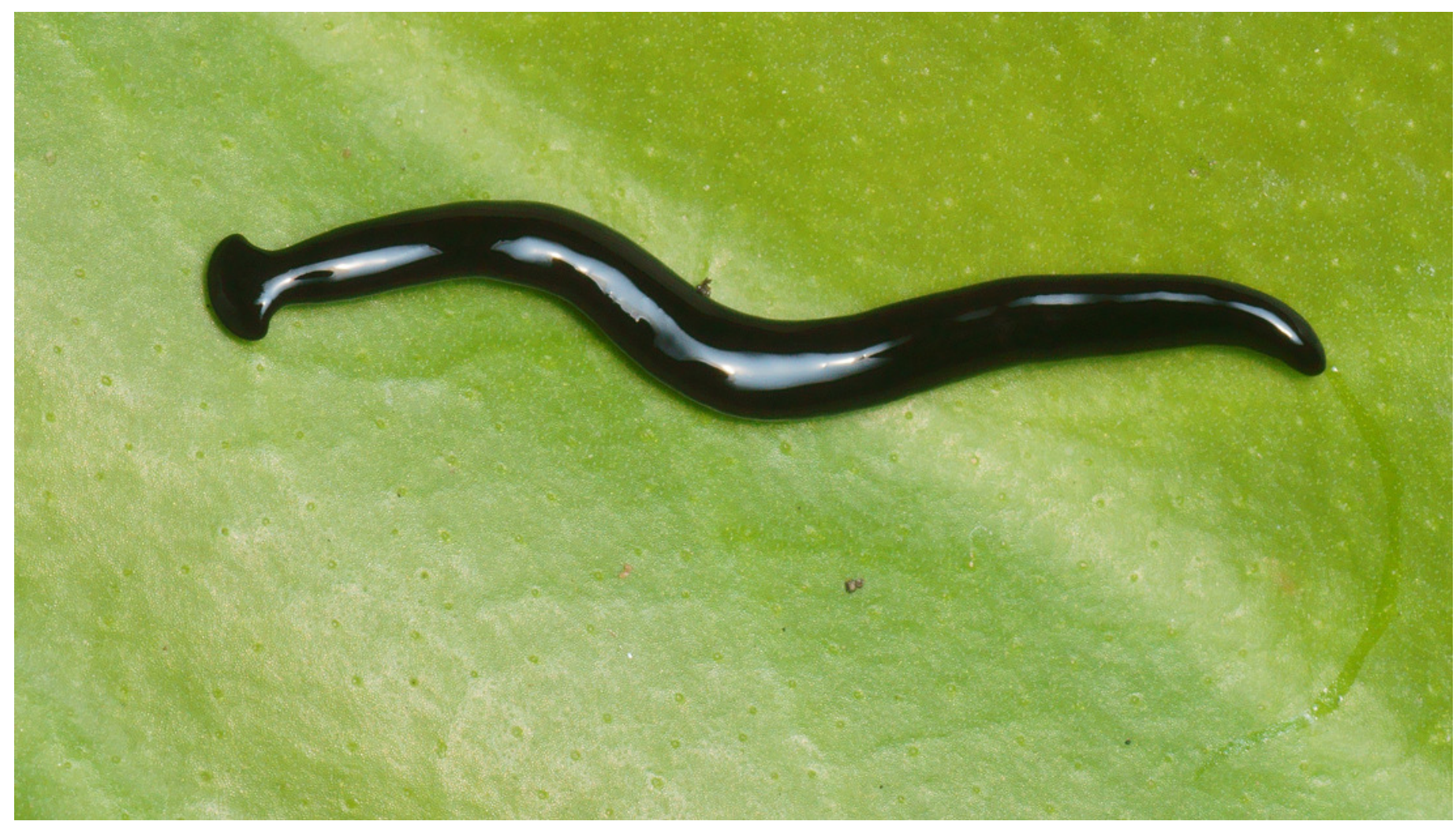




\section{Figure 3}

Humbertium covidum n. sp. from Italy, alive.

Lateral view showing locomotion and slime trail. Photo by Pierre Gros.

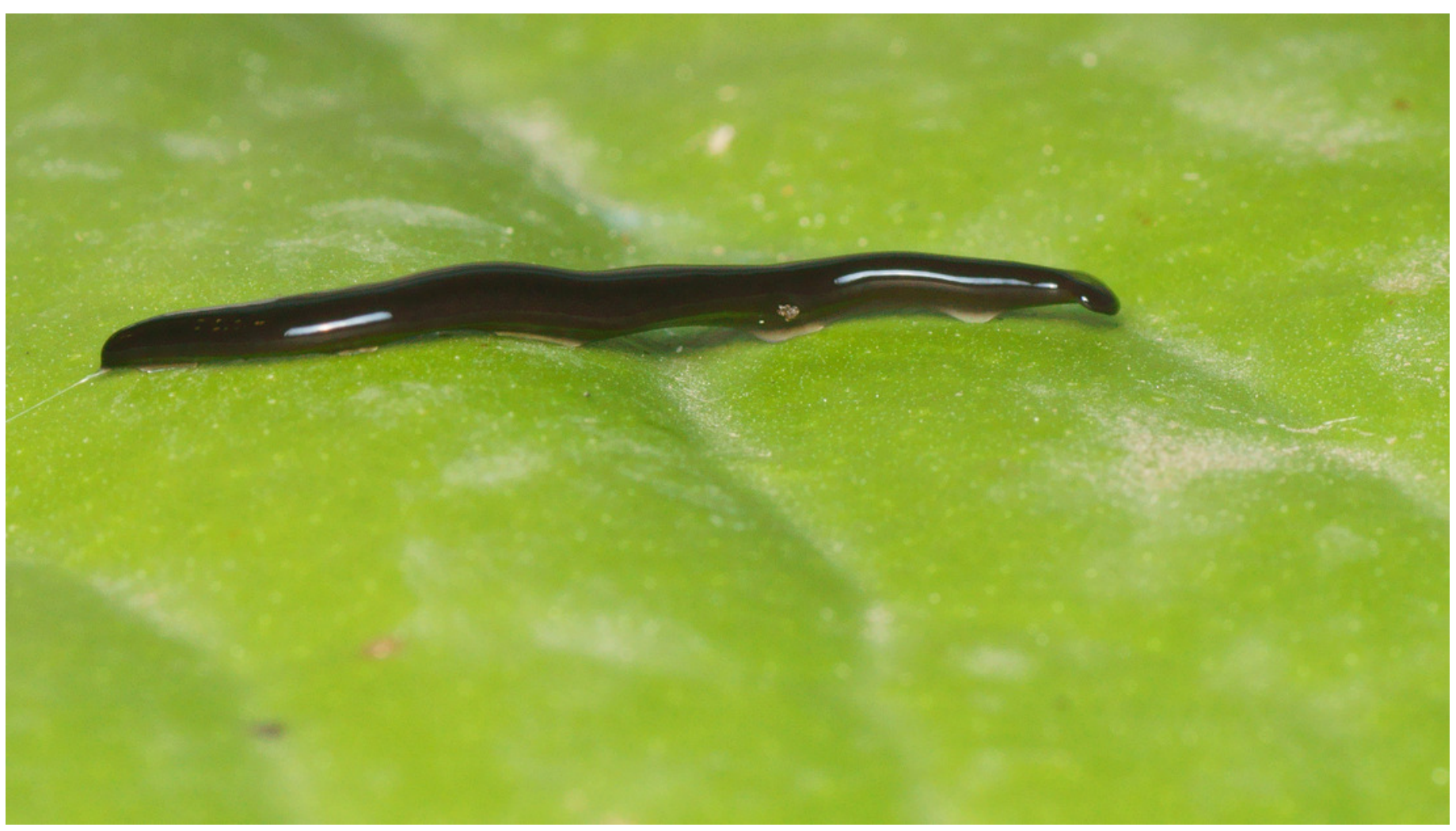




\section{Figure 4}

Humbertium covidum n. sp. from Italy, alive.

Lateral view showing locomotion and slime trail. Photo by Pierre Gros.

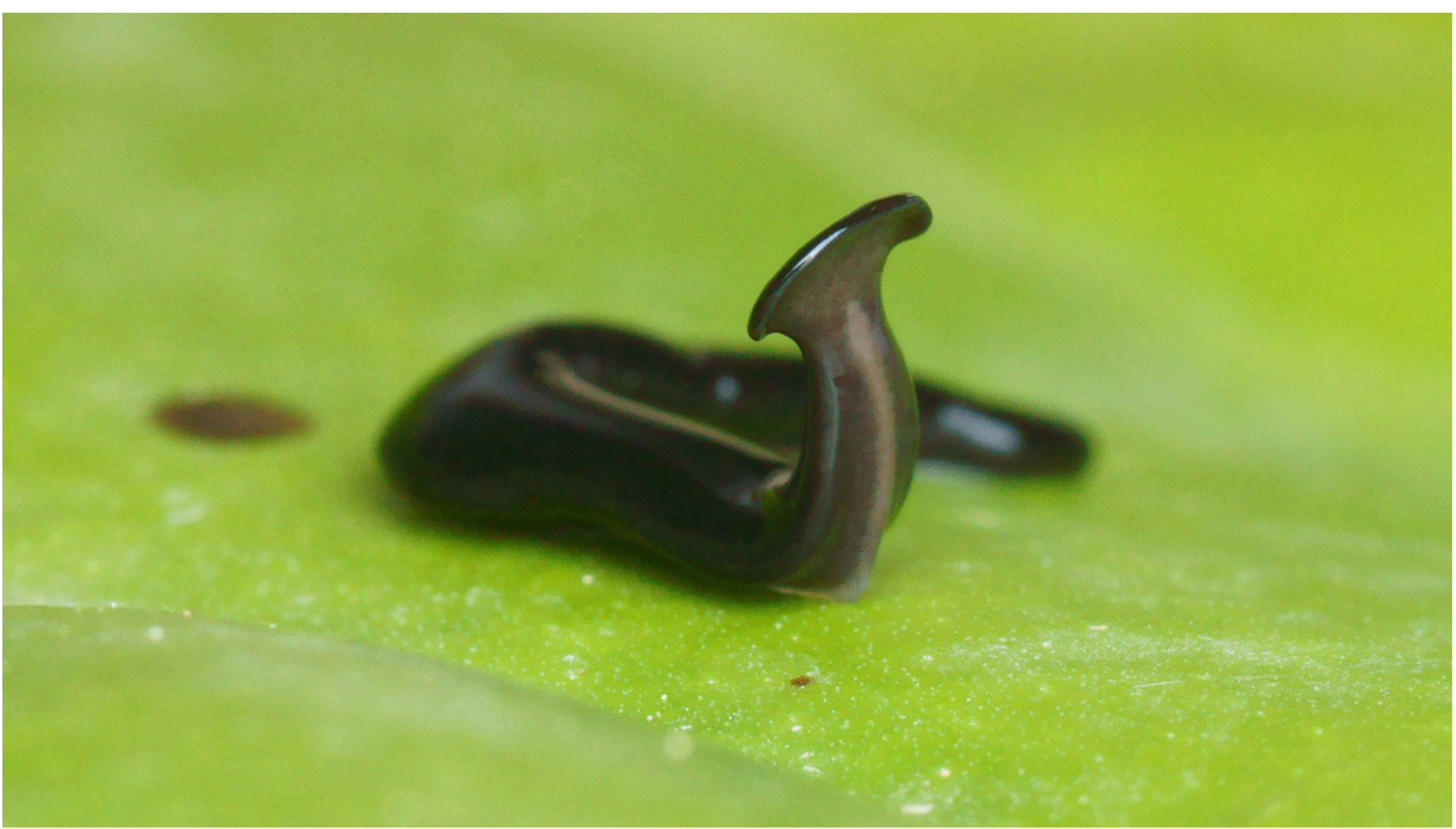




\section{Figure 5}

Humbertium covidum n. sp. from Italy, alive.

Individual with raised anterior end showing ventral surface. Photo by Pierre Gros.

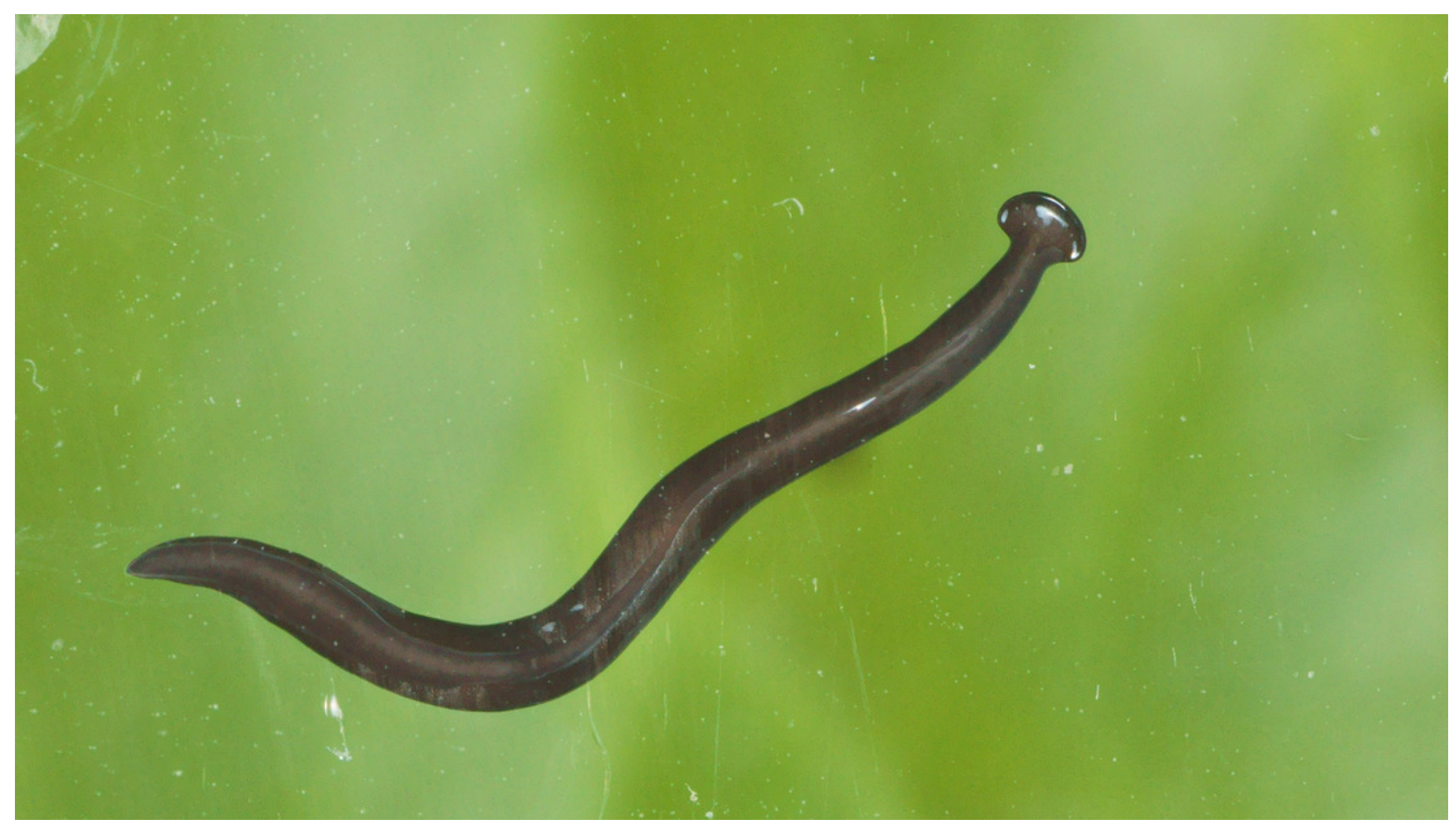




\section{Figure 6}

Humbertium covidum n. sp. from Italy, alive.

Ventral surface with typical headplate shape. Photo by Pierre Gros.

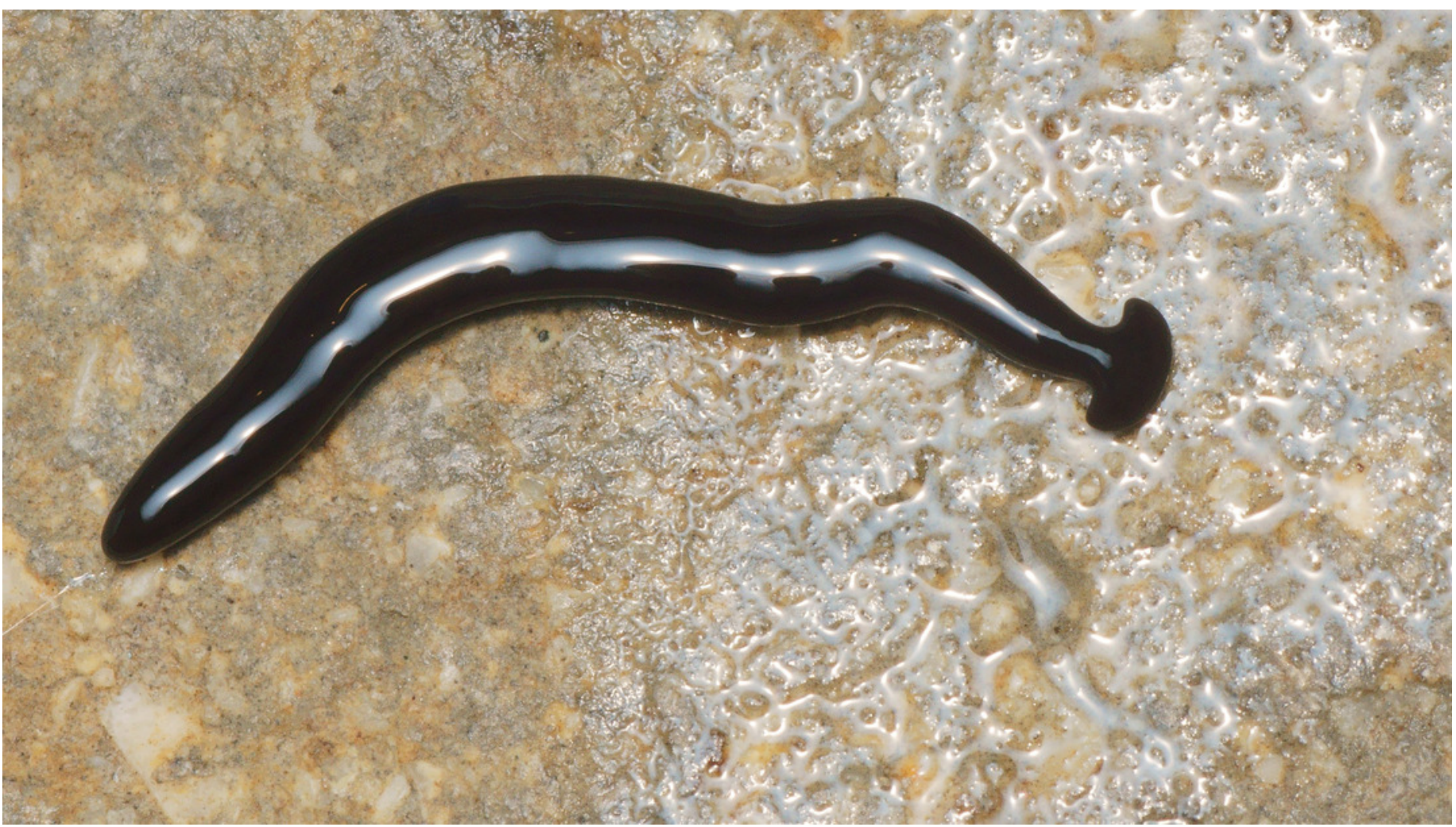




\section{Figure 7}

Humbertium covidum n. sp. from Billère, France, alive.

Lateral aspect. Photo by Pierre Gros.

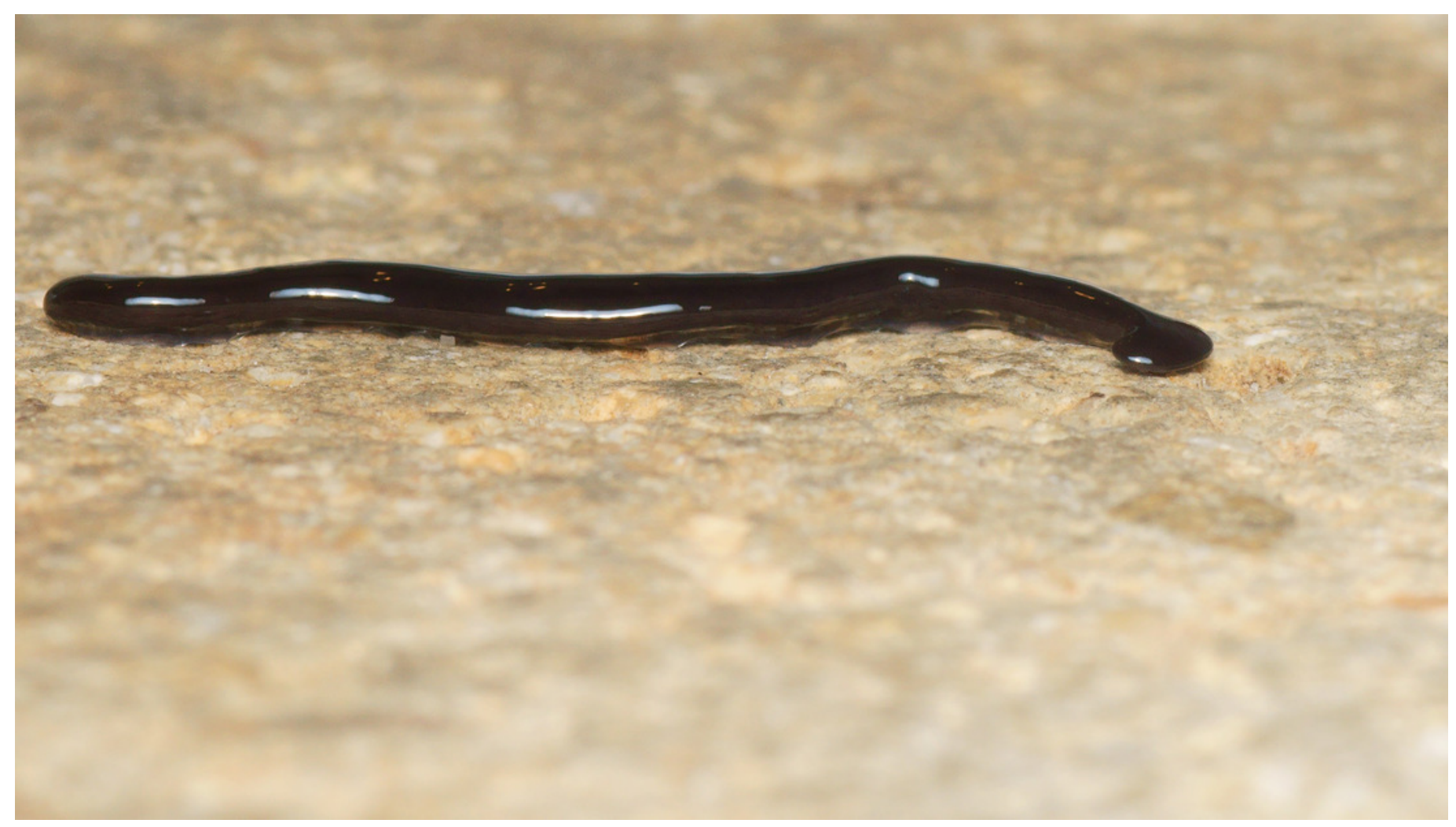




\section{Figure 8}

Humbertium covidum n. sp. from Billère, France, alive.

Lateral aspect showing extended papillae on headplate. Photo by Pierre Gros.

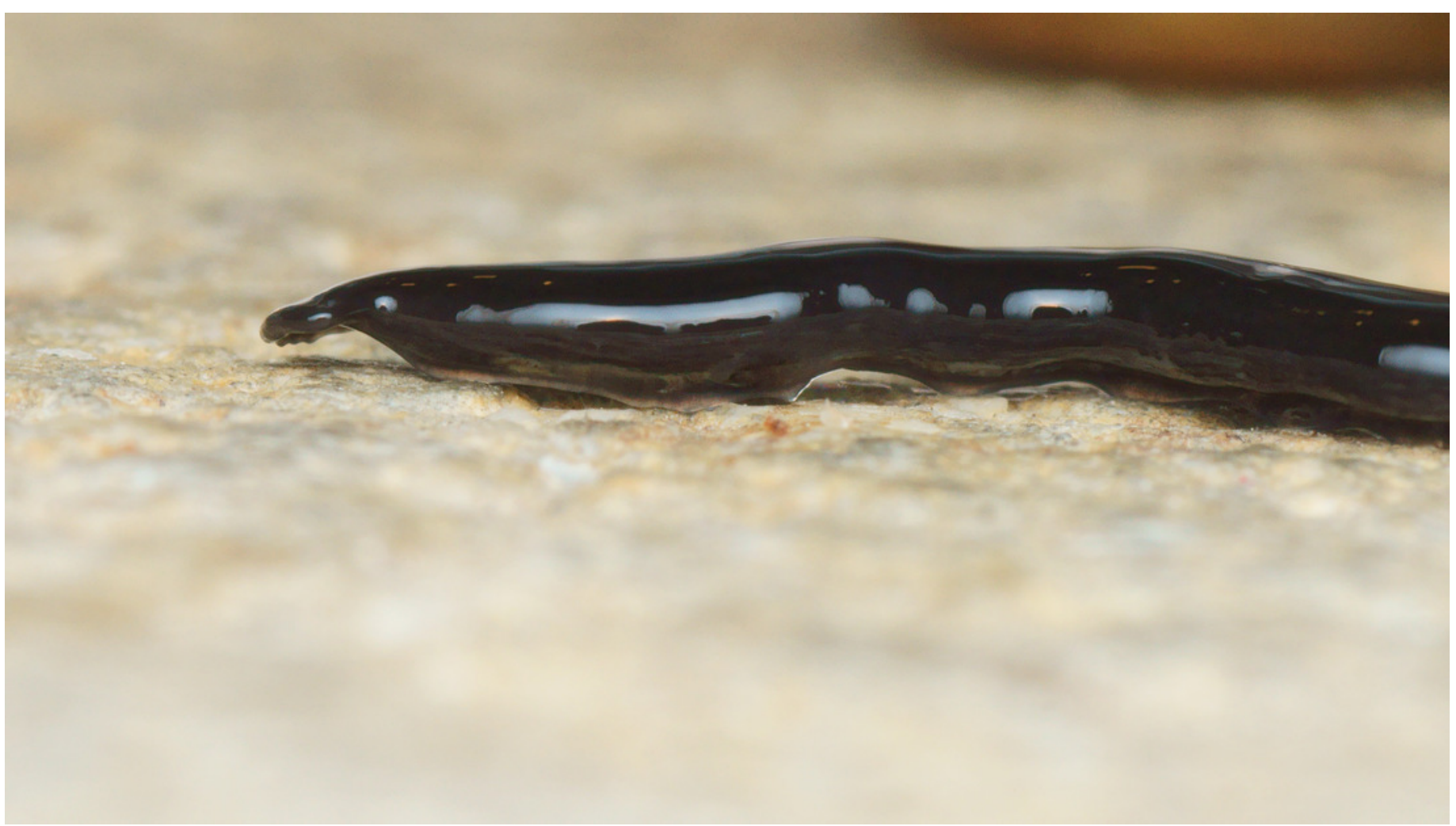




\section{Figure 9}

Humbertium covidum n. sp. from Billère, France, alive.

General dorsal aspect. Photo by Pierre Gros.

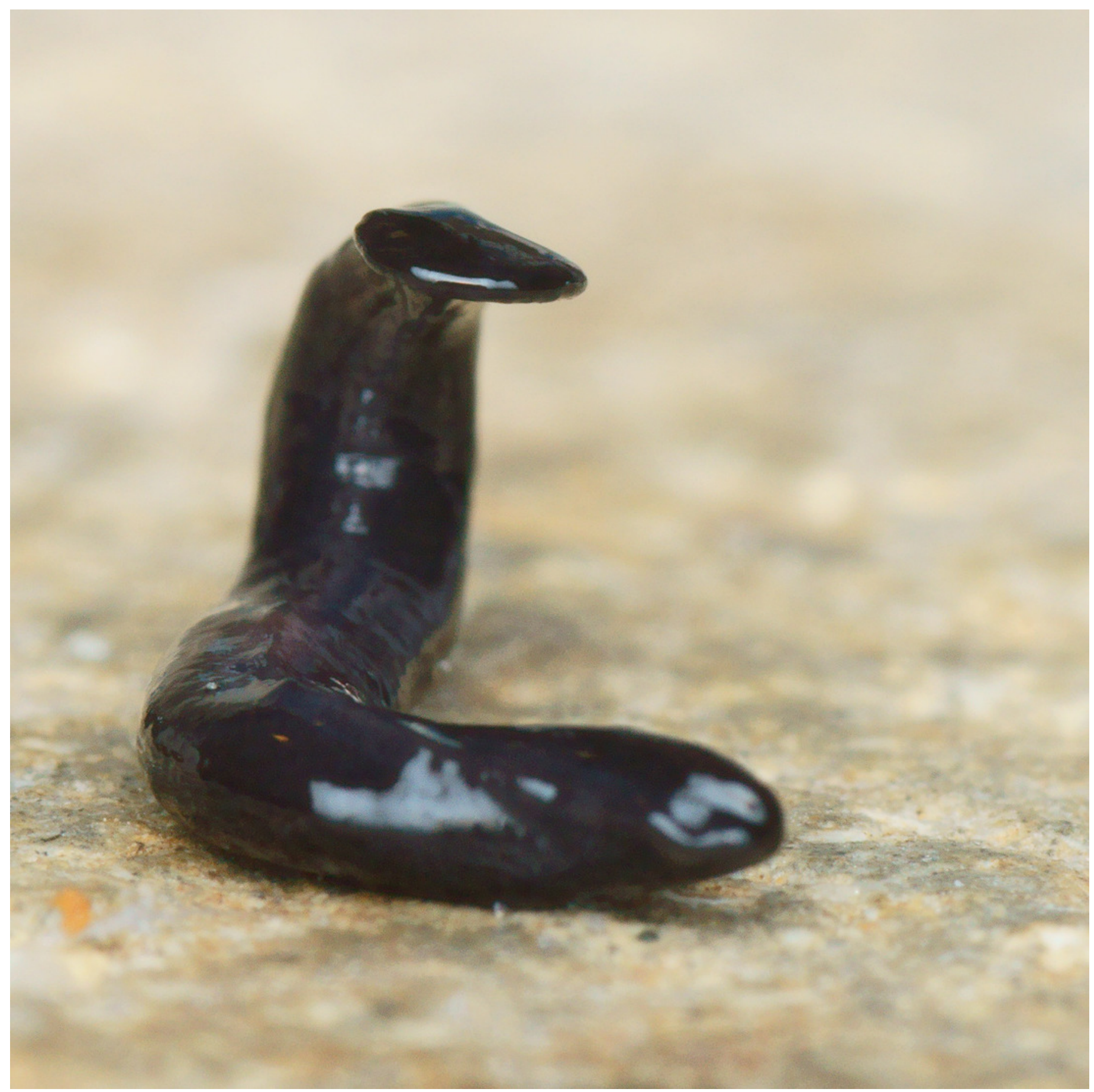




\section{Figure 10}

Humbertium covidum n. sp. from Billère, France, alive.

The flatworm seems to threaten a snail (unidentified species). Photo by Pierre Gros.

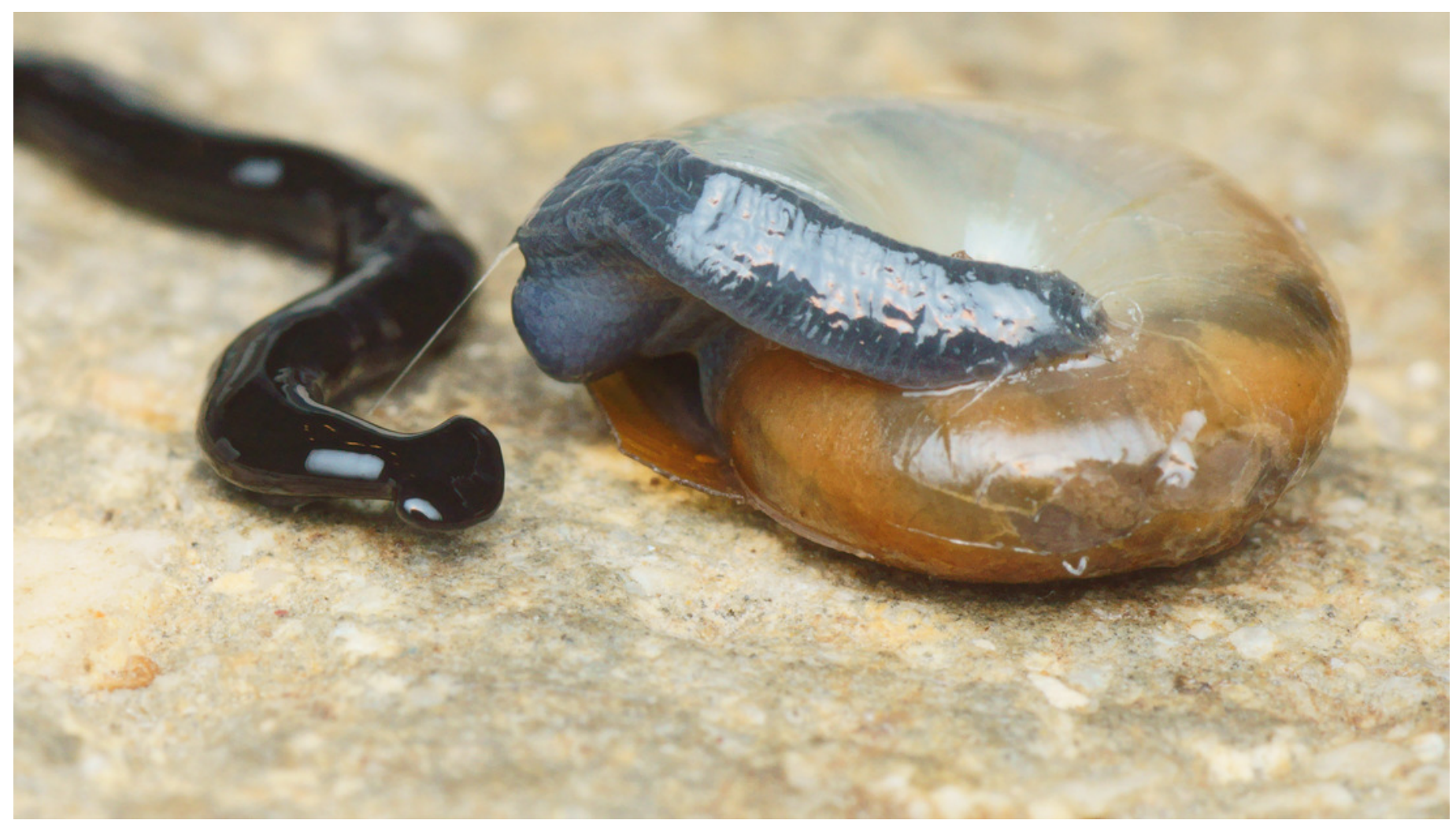




\section{Figure 11}

Humbertium covidum n. sp. from Saint-Pée-sur-Nivelle, France, preserved.

Specimen MNHN JL090, preserved specimen, dorsal aspect. Showing the partly protruded pharynx. Photo by Jean-Lou Justine. Reproduced from Figure 20 of Justine et al., 2018. 


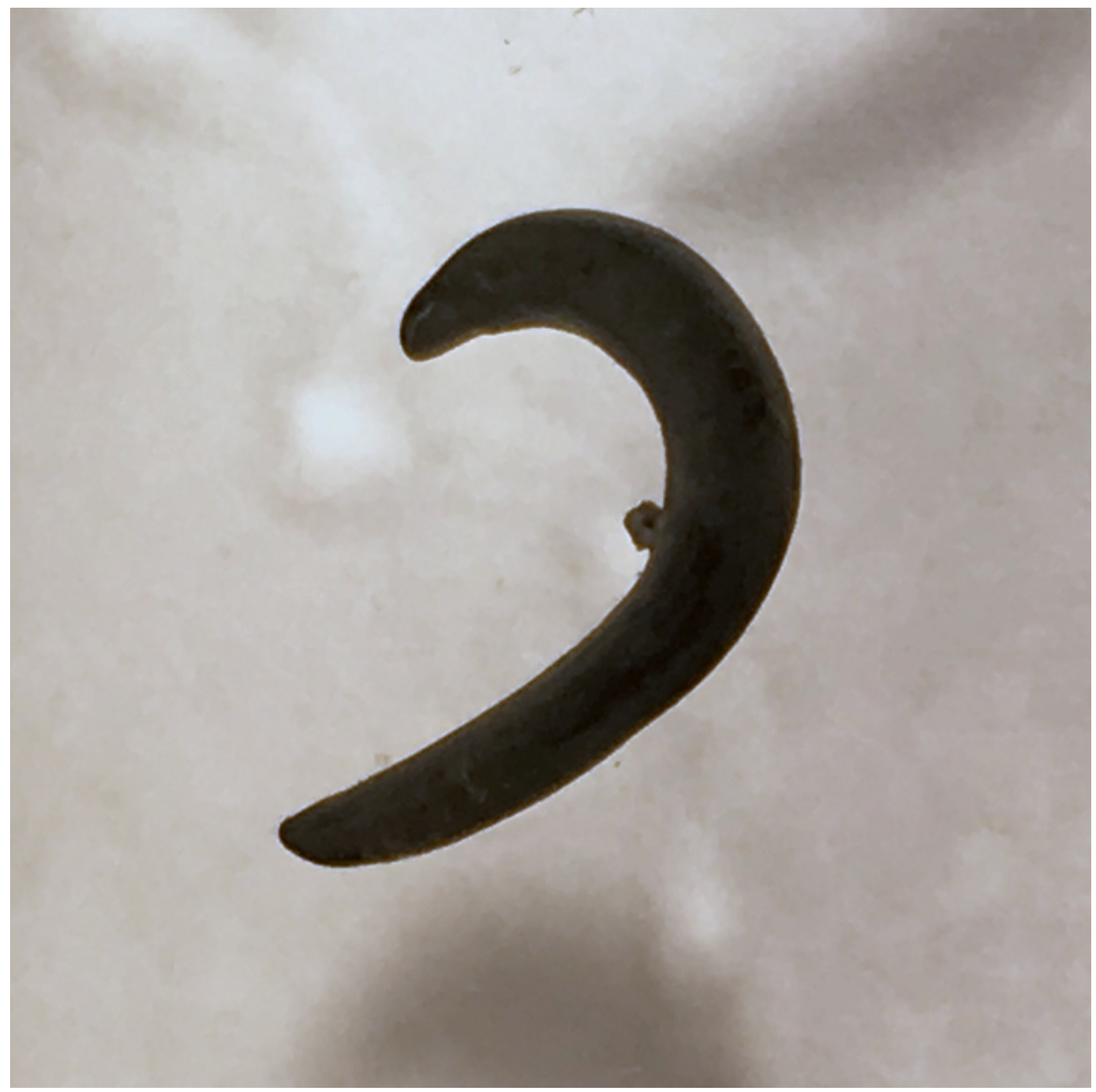




\section{Figure 12}

Humbertium covidum n. sp. from Saint-Pée-sur-Nivelle, France, preserved.

Specimen MNHN JL090. Preserved specimen, ventral aspect. The ventral ground colour is grey, with the creeping sole a lighter tone. The pharynx is slightly protruded from the mouth, and the gonopore is evident as a small transverse white slit on the creeping sole some $2 \mathrm{~mm}$ below to the mouth. Scale is in $\mathrm{mm}$. Photo by Jean-Lou Justine. Reproduced from Figure 21 of Justine et al., 2018. 


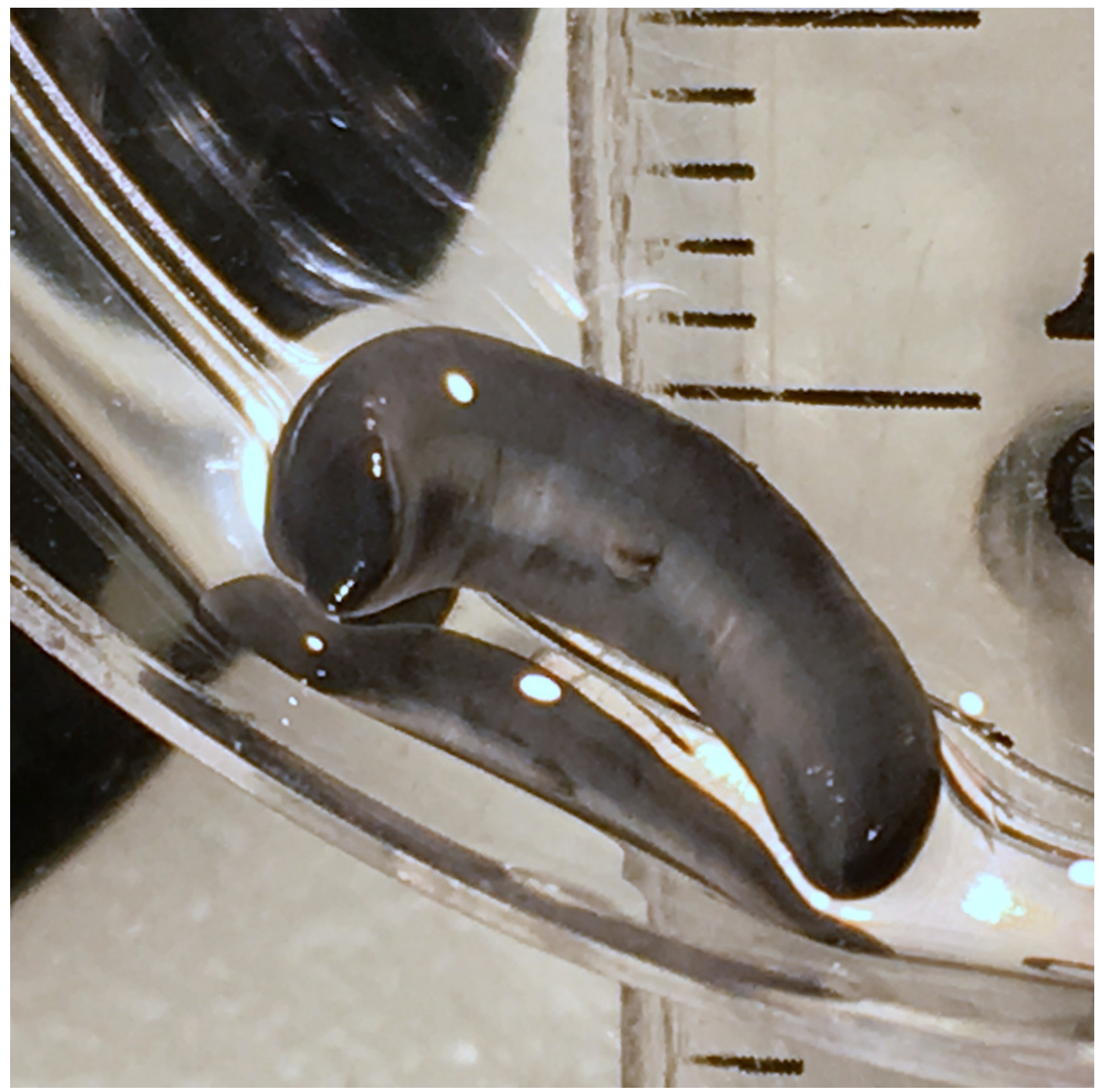




\section{Figure 13}

Anatomy of Humbertium covidum n. sp., pre-pharyngeal region.

Holotype, specimen MNHN JL351B. Pre-pharyngeal region, transverse section. Arrows indicate the extent of the creeping sole. Photo by Leigh Winsor.

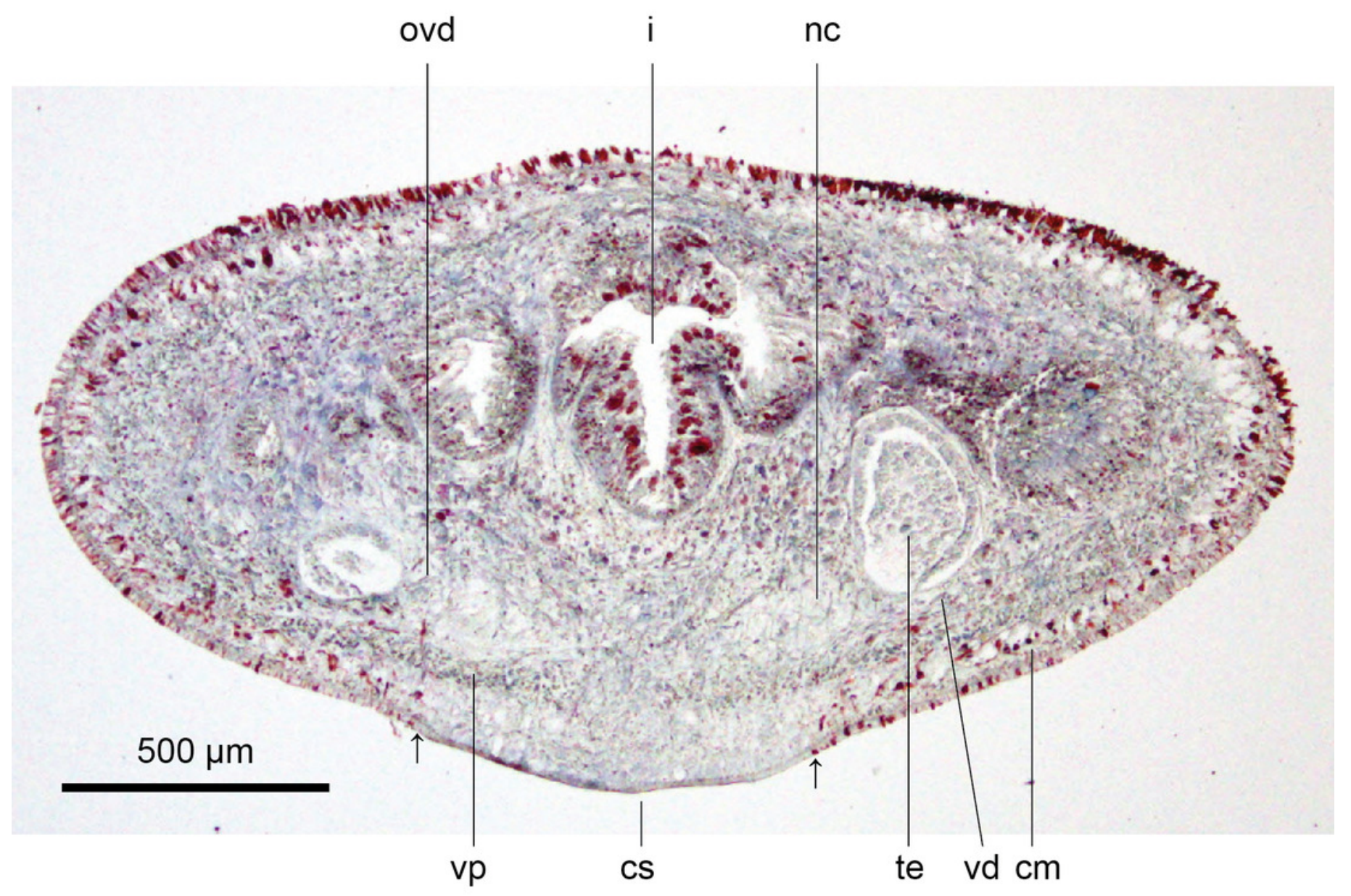




\section{Figure 14}

Anatomy of Humbertium covidum n. sp, ventral longitudinal muscular plate.

Holotype, specimen MNHN JL351B. Lateral body showing ventral longitudinal muscular plate.

Photo by Leigh Winsor. 


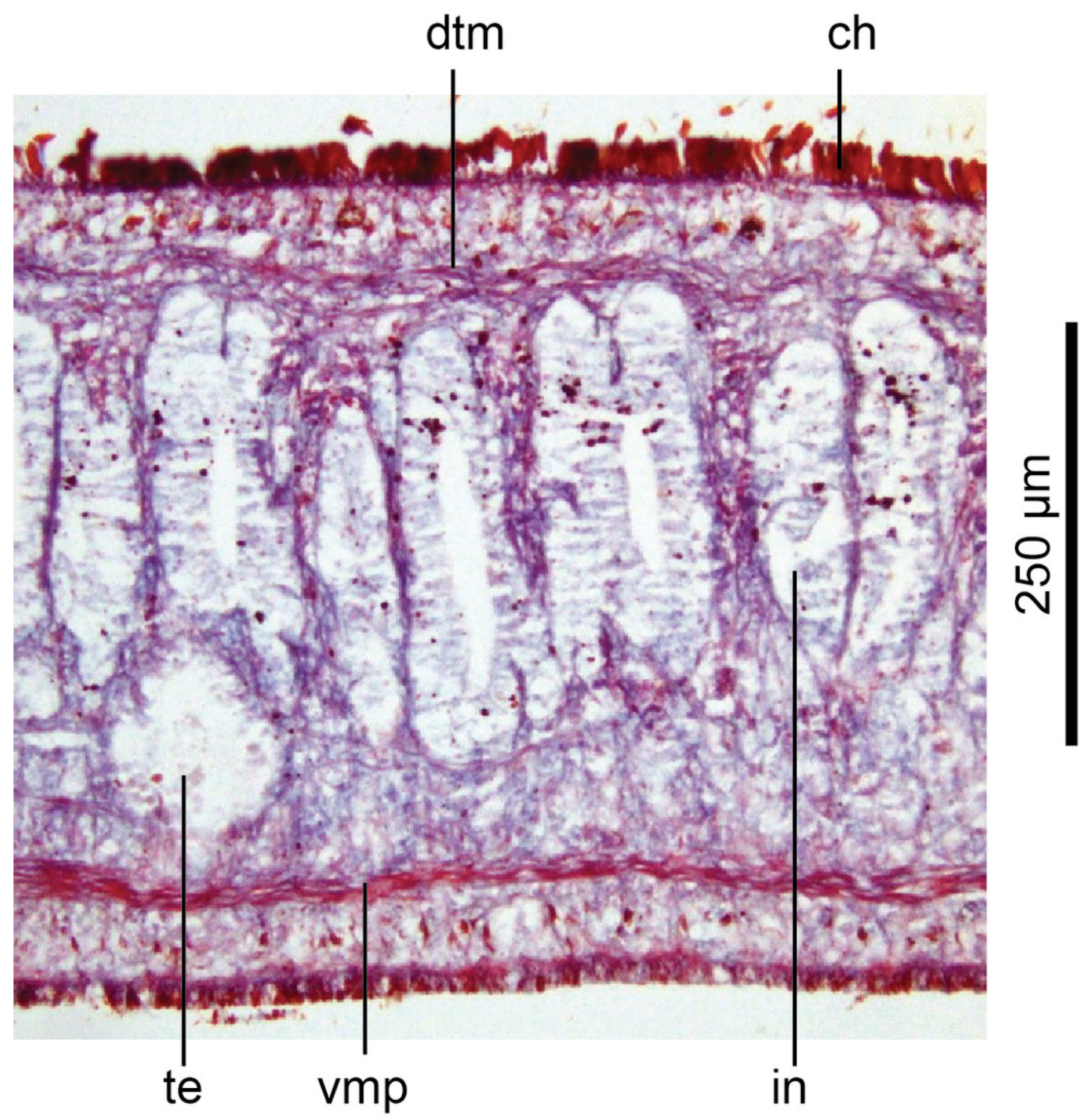


Figure 15

Anatomy of Humbertium covidum n. sp., pharynx.

Holotype, specimen MNHN JL351B. Pharynx, sagittal section. Photo by Leigh Winsor. 


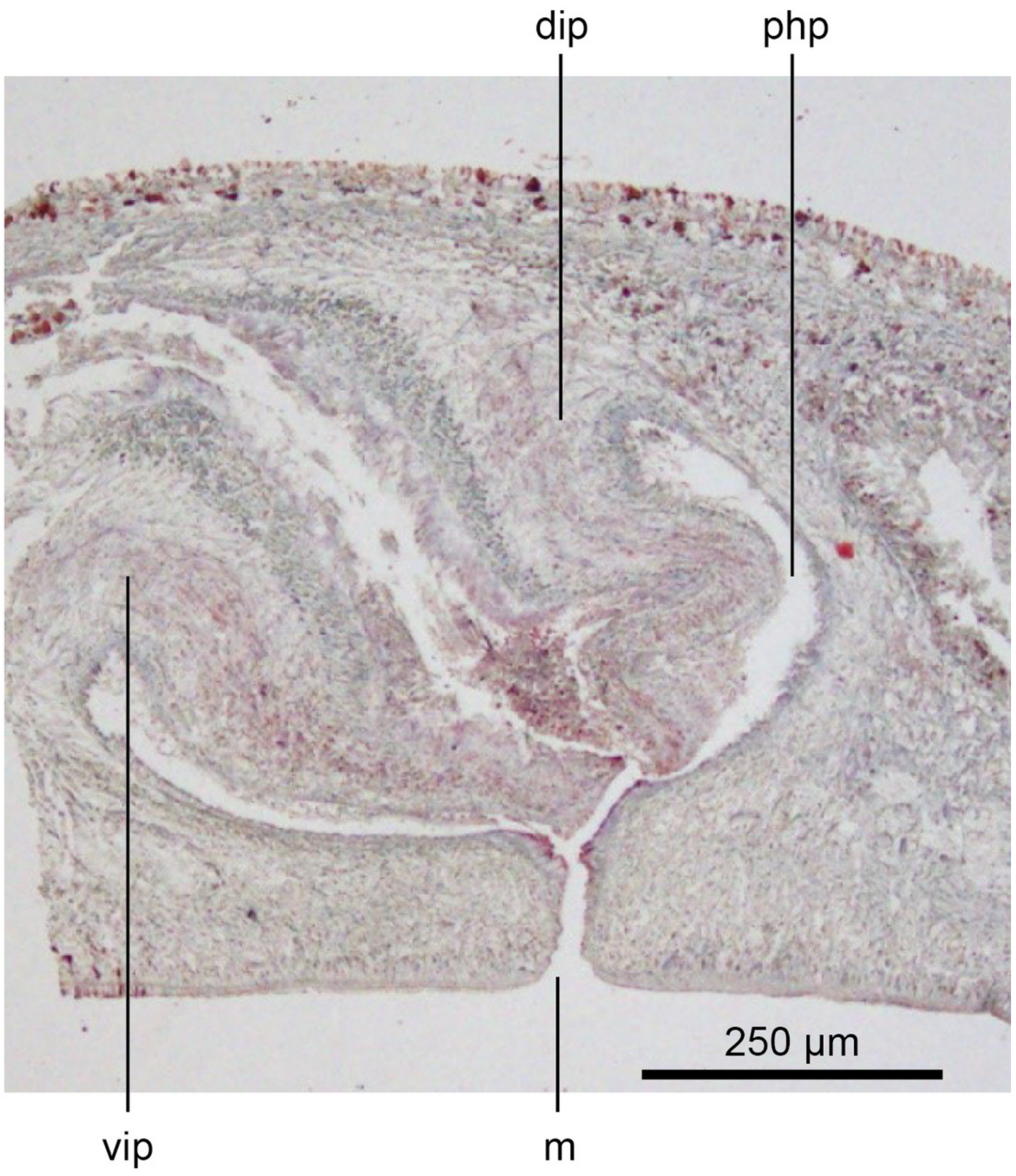




\section{Figure 16}

Morphology of Humbertium covidum n. sp., eye pattern.

Paratype JL 351C. Headplate showing the dorsal and ventral eye patterns in a cleared specimen. The headplate is curled ventrad. Drawing by Leigh Winsor. 


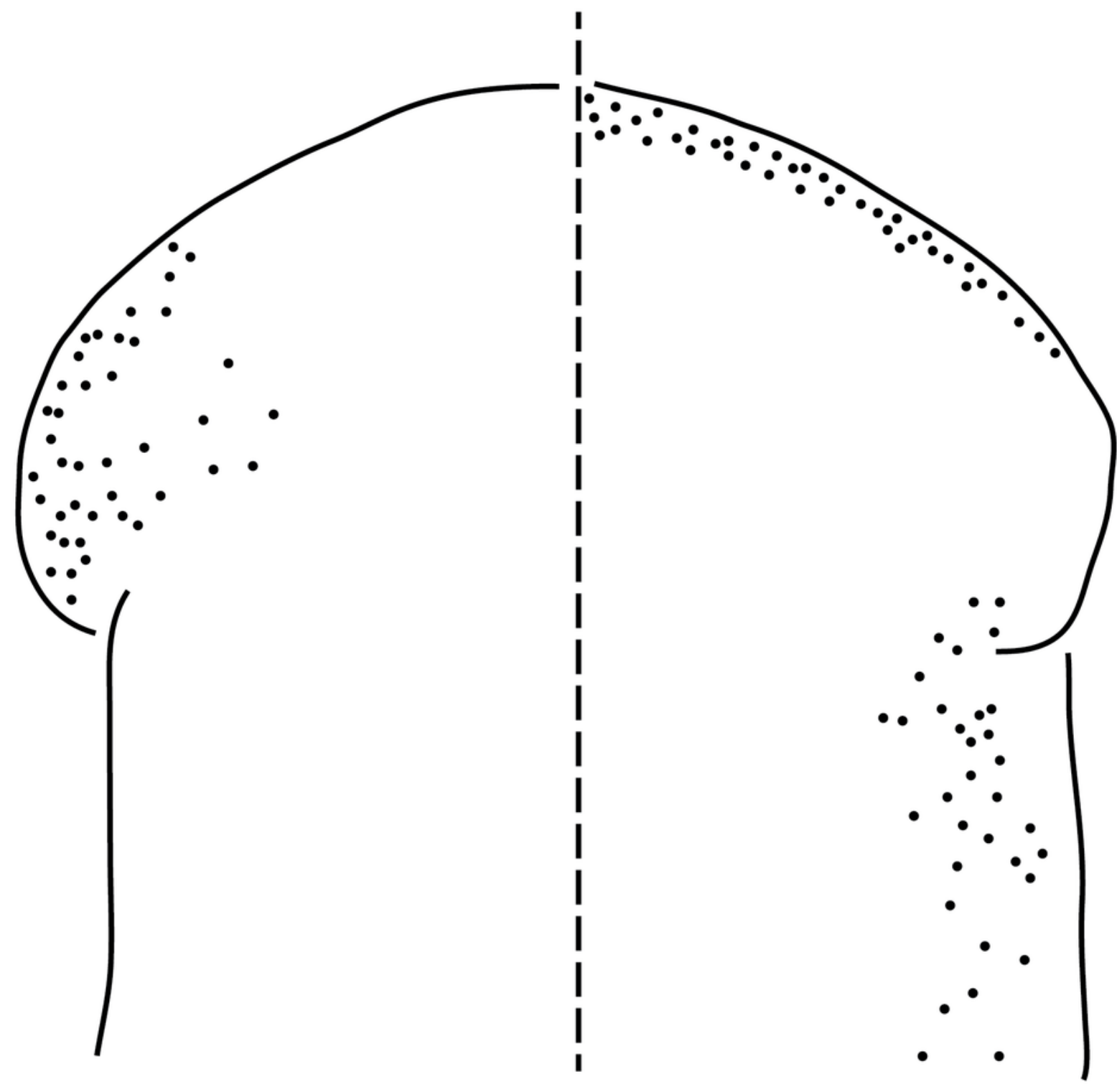

dorsal 


\section{Figure 17}

Anatomy of Humbertium covidum n. sp., composite drawing of copulatory organs.

Holotype, specimen MNHN JL351B. Composite reconstruction of the copulatory organs, sagittal view. The dashed line in the common atrium indicates the extent of the glandular mesenchyme forming the common genital canal. Anterior: left. Drawing by Leigh Winsor. 


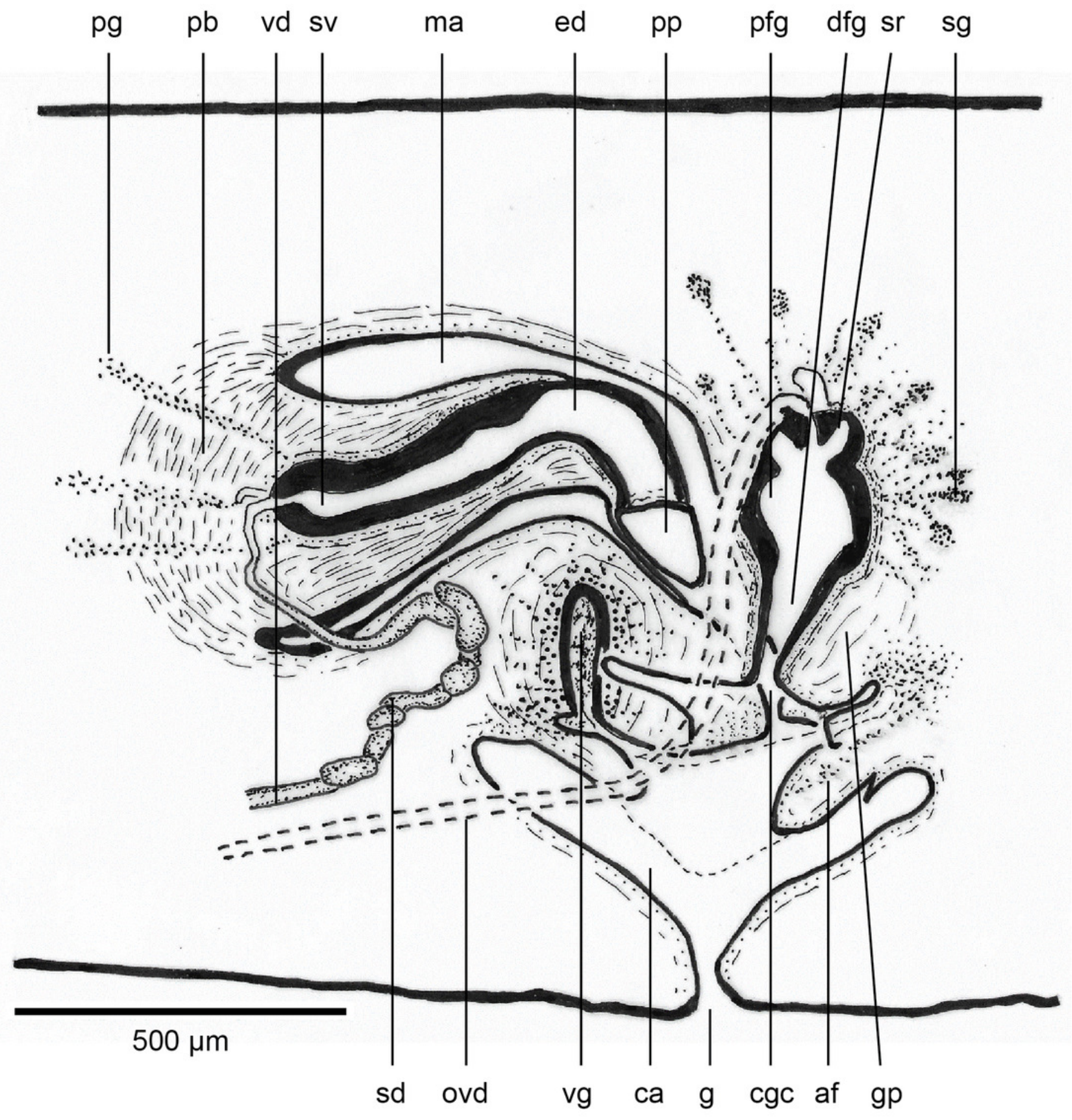




\section{Figure 18}

Anatomy of Humbertium covidum n. sp., level of gonopore.

Holotype, specimen MNHN JL351B. Copulatory organs at the level of the gonopore, with the female glandular canal entering the common genital canal at the point where it communicates with the common atrium. Anterior: left. Photo by Leigh Winsor.

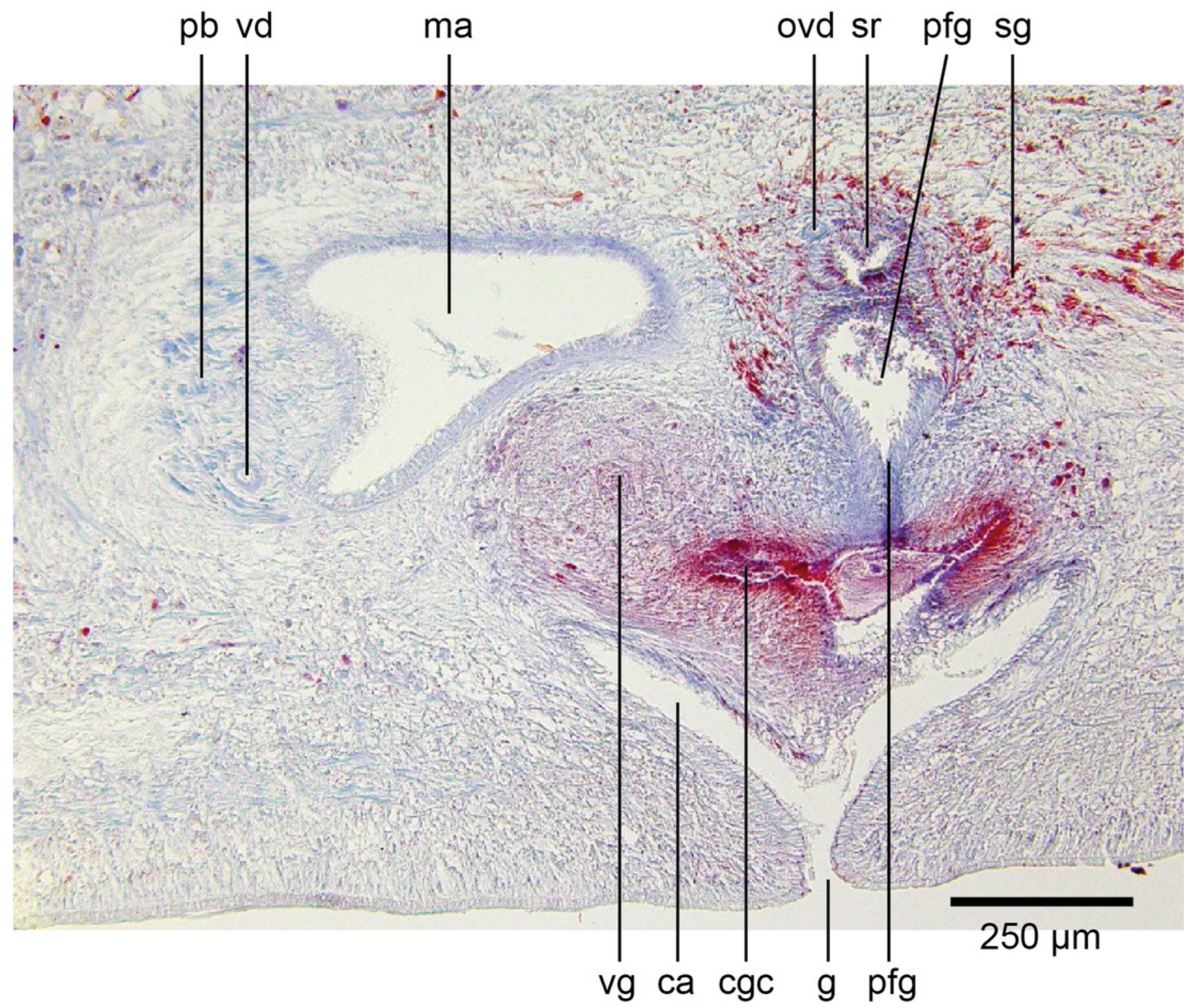




\section{Figure 19}

Anatomy of Humbertium covidum n. sp., putative common genital canal.

Paratype, specimen MNHN JL351C. Glandular mesenchyme of the putative common genital canal on the left side of the body. Anterior: left. Photo by Leigh Winsor. 


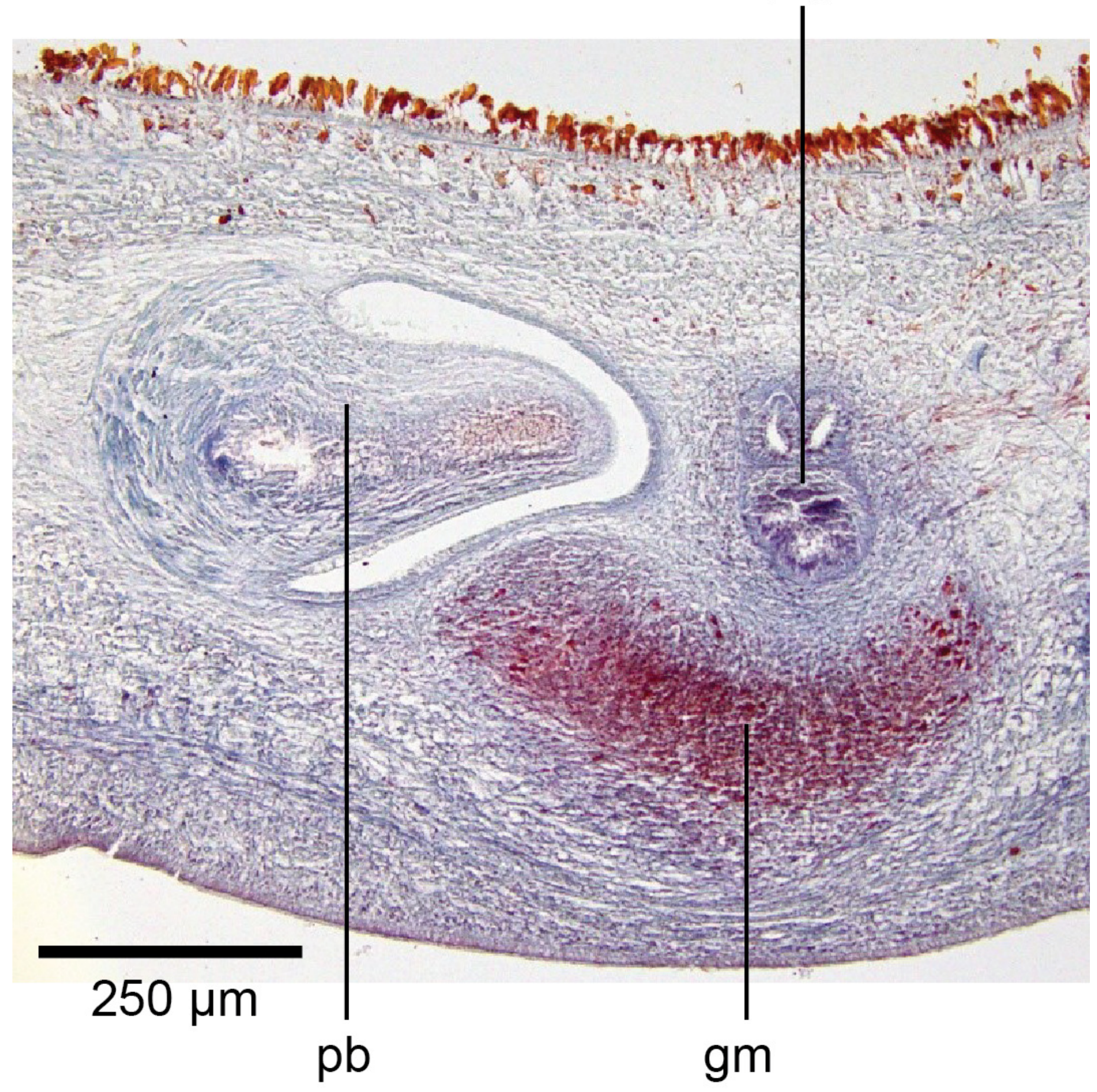


Figure 20

Anatomy of Humbertium covidum n. sp., common genital canal.

Paratype, specimen MNHN JL351C. The beginning of the slit-like common genital canal. Anterior: left. Photo by Leigh Winsor. 


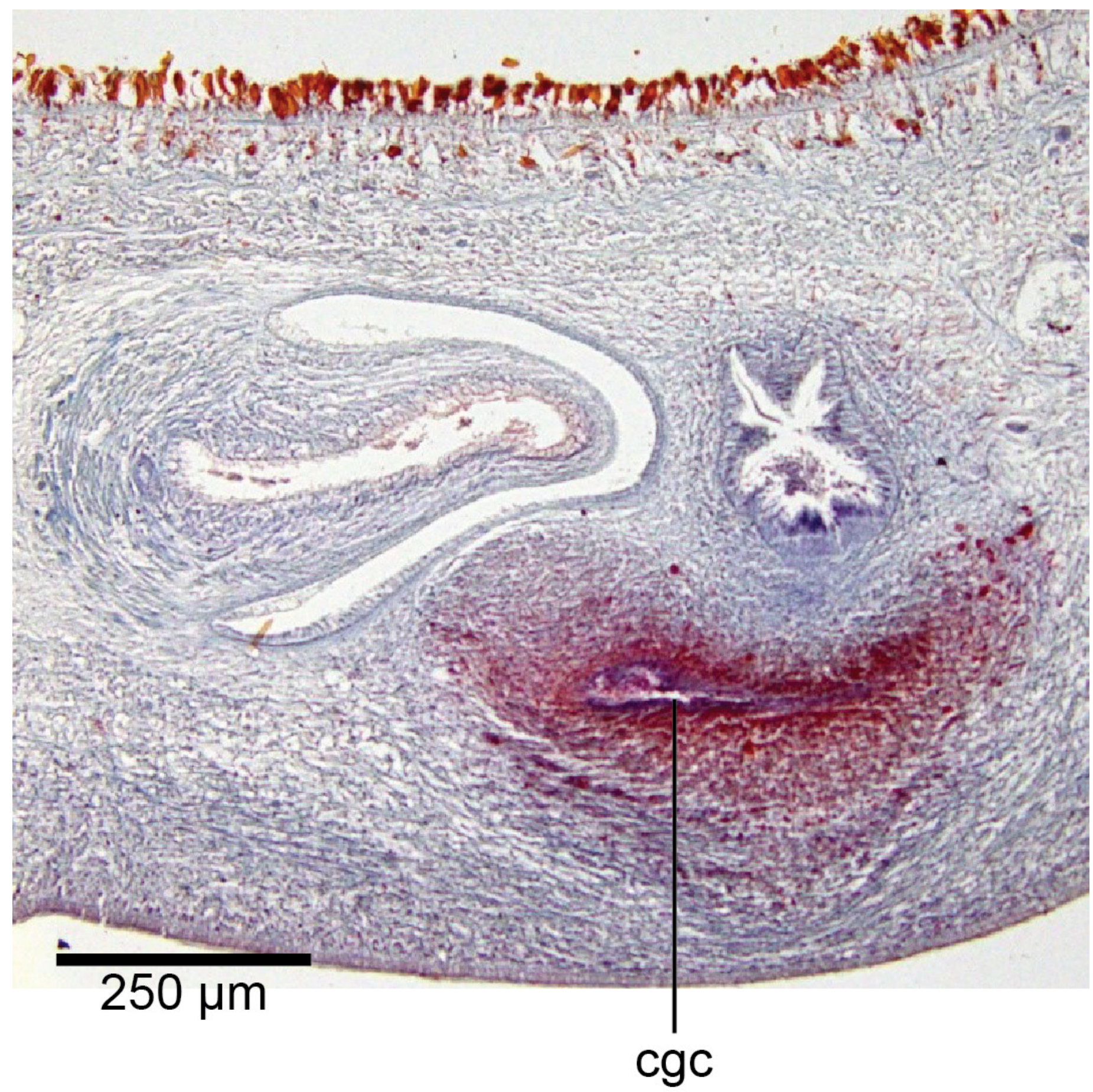




\section{Figure 21}

Anatomy of Humbertium covidum n. sp., male atrium.

Paratype, specimen MNHN JL351C. The point where the male atrium is about to open into the common genital canal which has not yet opened into the common atrium. Anterior: left. Photo by Leigh Winsor.

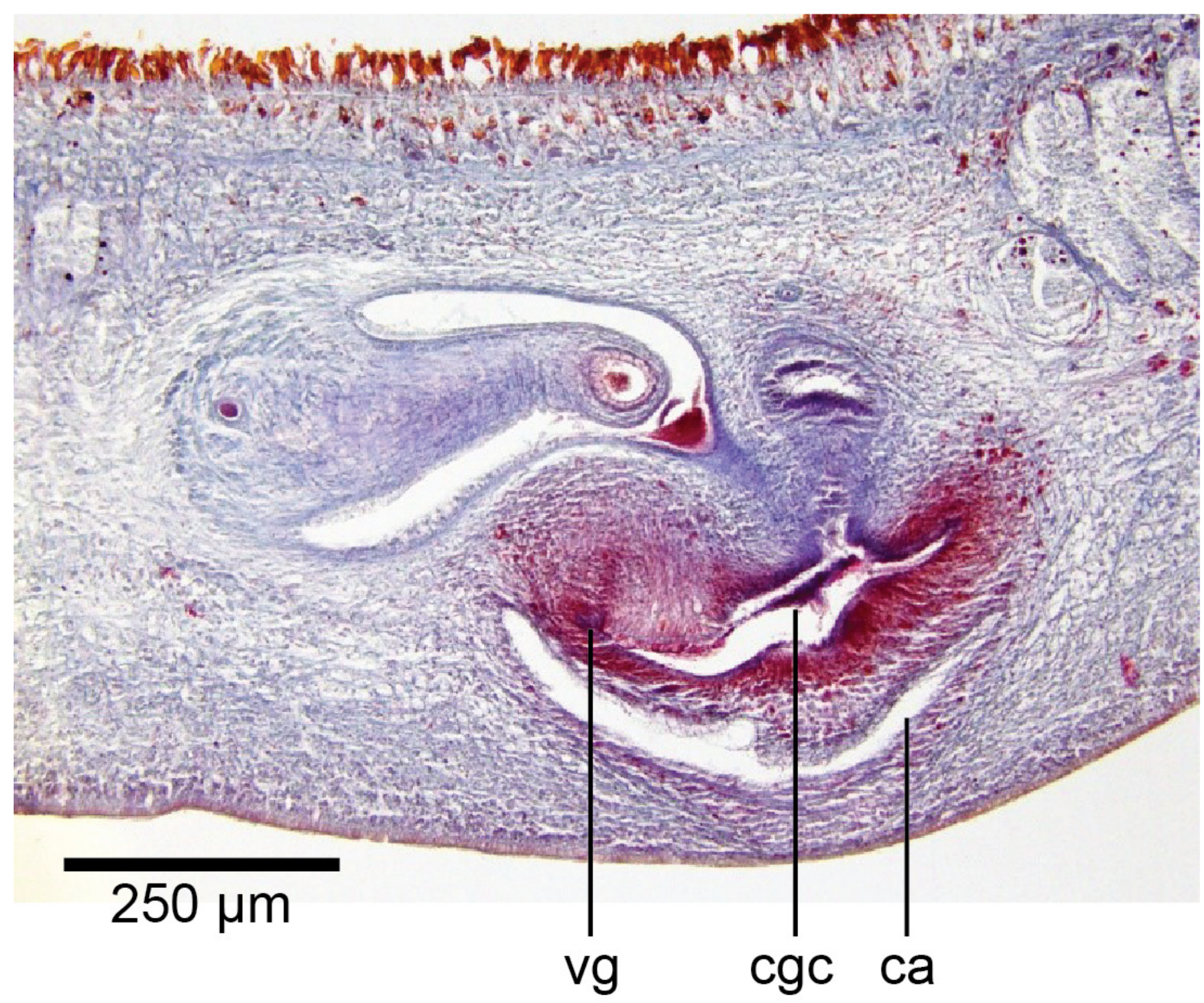




\section{Figure 22}

Anatomy of Humbertium covidum n. sp., viscid gland.

Holotype, specimen MNHN JL351B. The viscid gland at the anteriad end of the genital pad below the male organs. Anterior: left. Photo by Leigh Winsor.

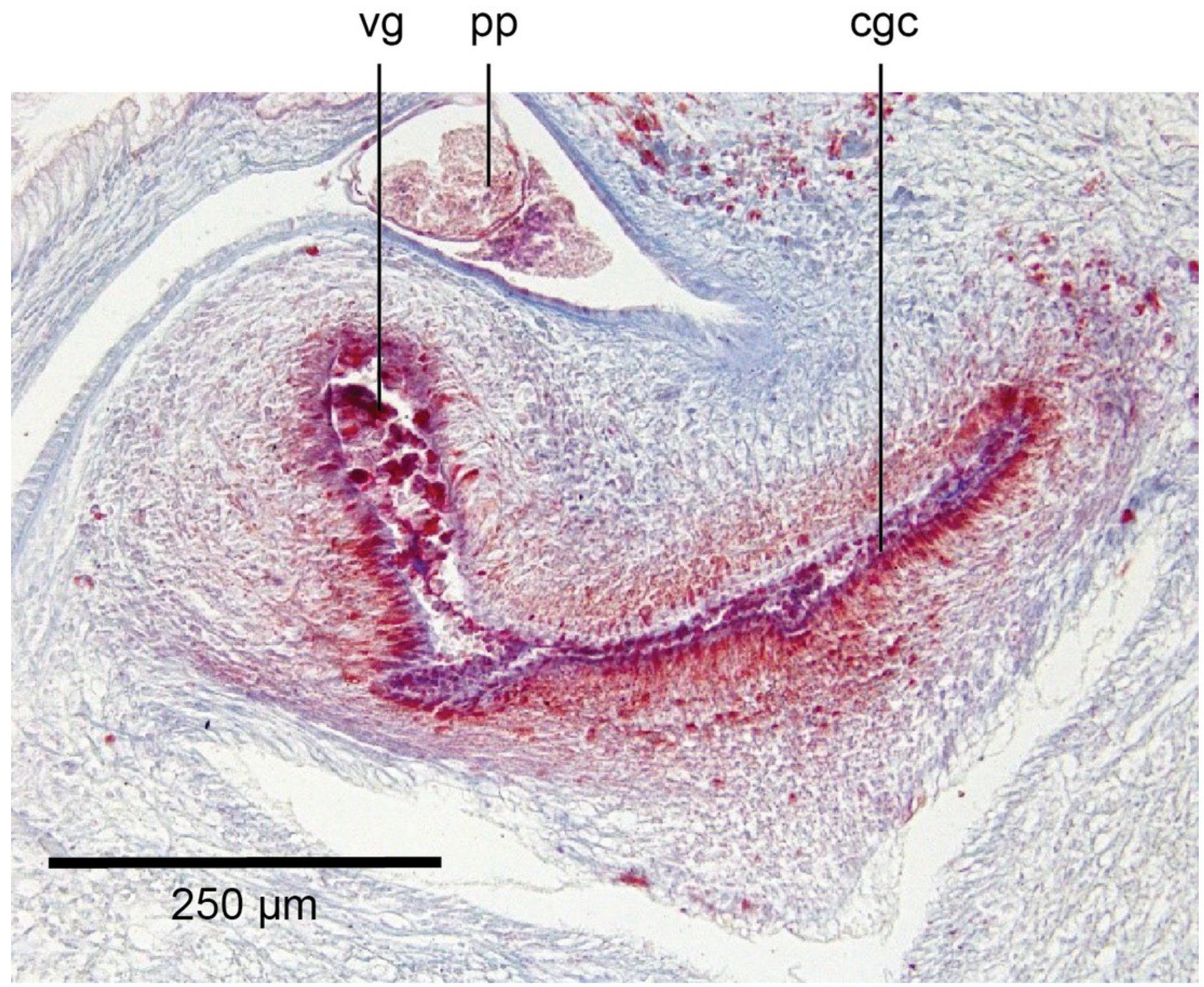




\section{Figure 23}

Anatomy of Humbertium covidum n. sp., viscid gland and erythrophil glands

Holotype, specimen MNHN JL351B. The glandular duct of the viscid gland, and erythrophil glands in the atrial crease. Anterior: left. Photo by Leigh Winsor.

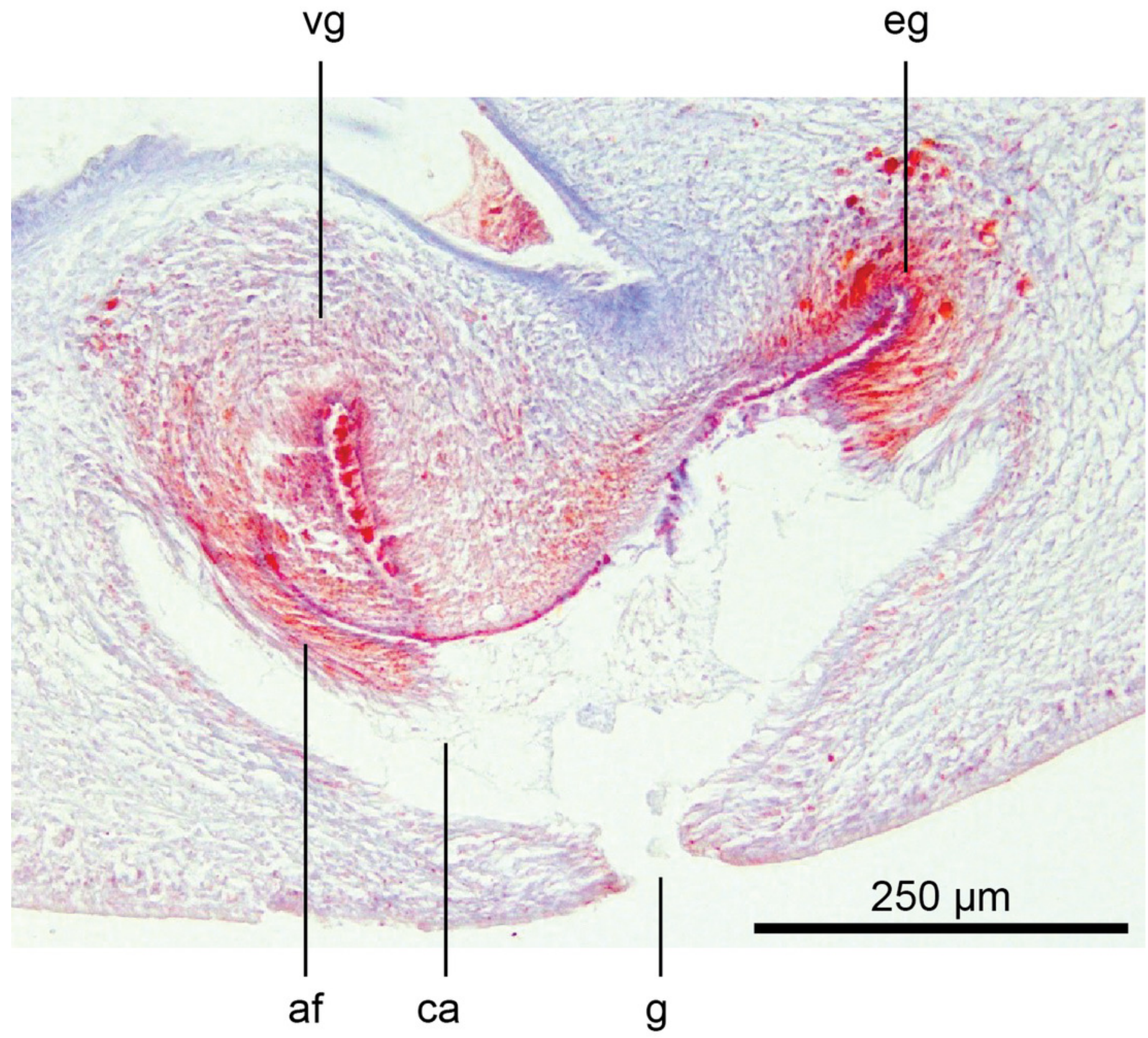




\section{Figure 24}

Diversibipalium mayottensis $\mathrm{n} . \mathrm{sp}$, alive.

Specimen MNHN JL282 from Mayotte, Indian Ocean, dorsal aspect. The headplate of this small planarian is a rusty-brown colour that extends to some irregular patches on the 'neck.' The dorsal ground colour is an iridescent blue-green ('dark turquoise glitter'). Photo by Laurent Charles. Reproduced from Figure 23 in Justine et al., 2018. 


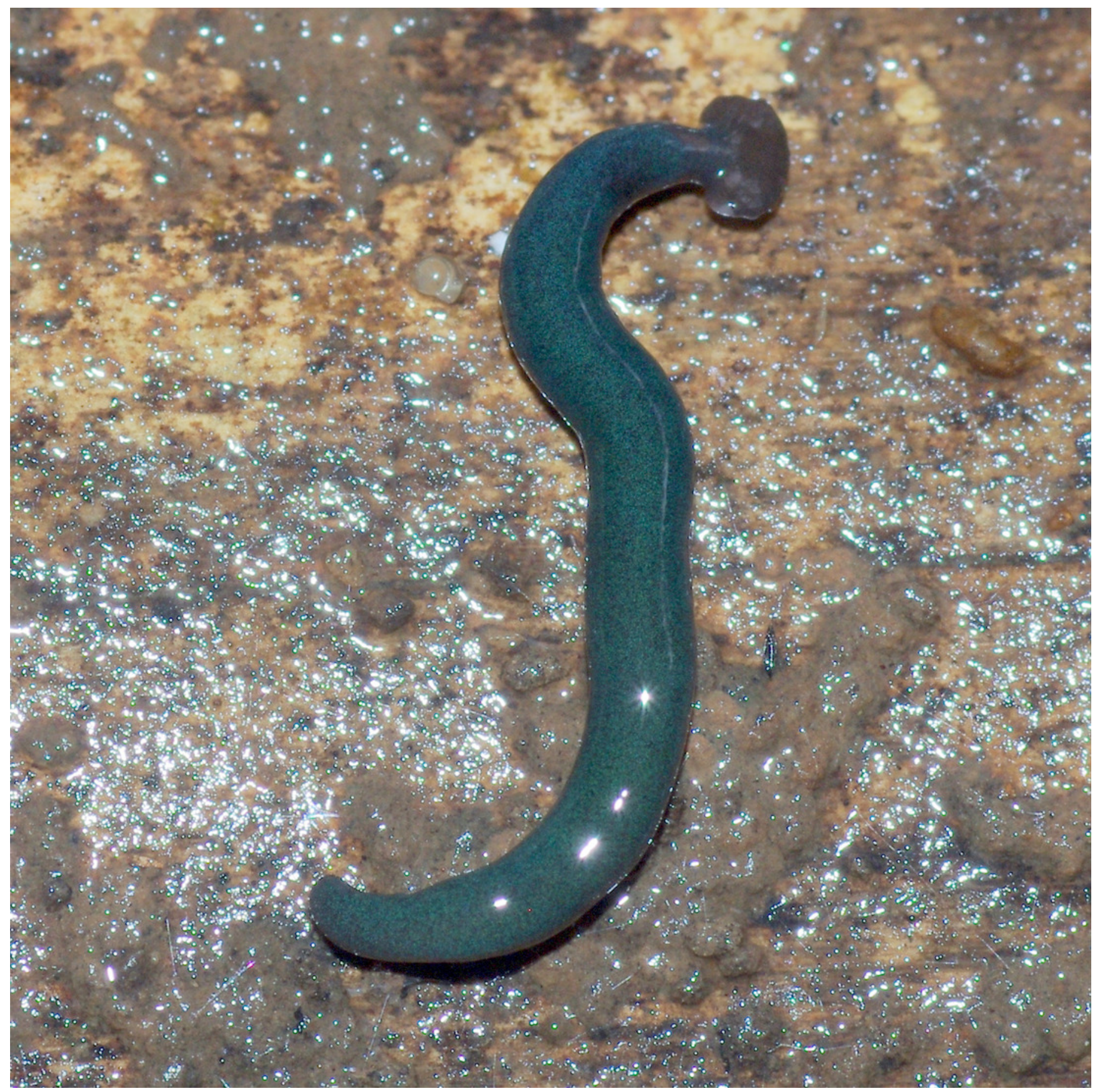




\section{Figure 25}

Diversibipalium mayottensis $\mathrm{n} . \mathrm{sp}$, alive.

Specimen MNHN JL282 from Mayotte, Indian Ocean, dorsal aspect. Same specimen as in

Figure 24. Photo by Laurent Charles. Reproduced from Figure 24 in Justine et al., 2018 


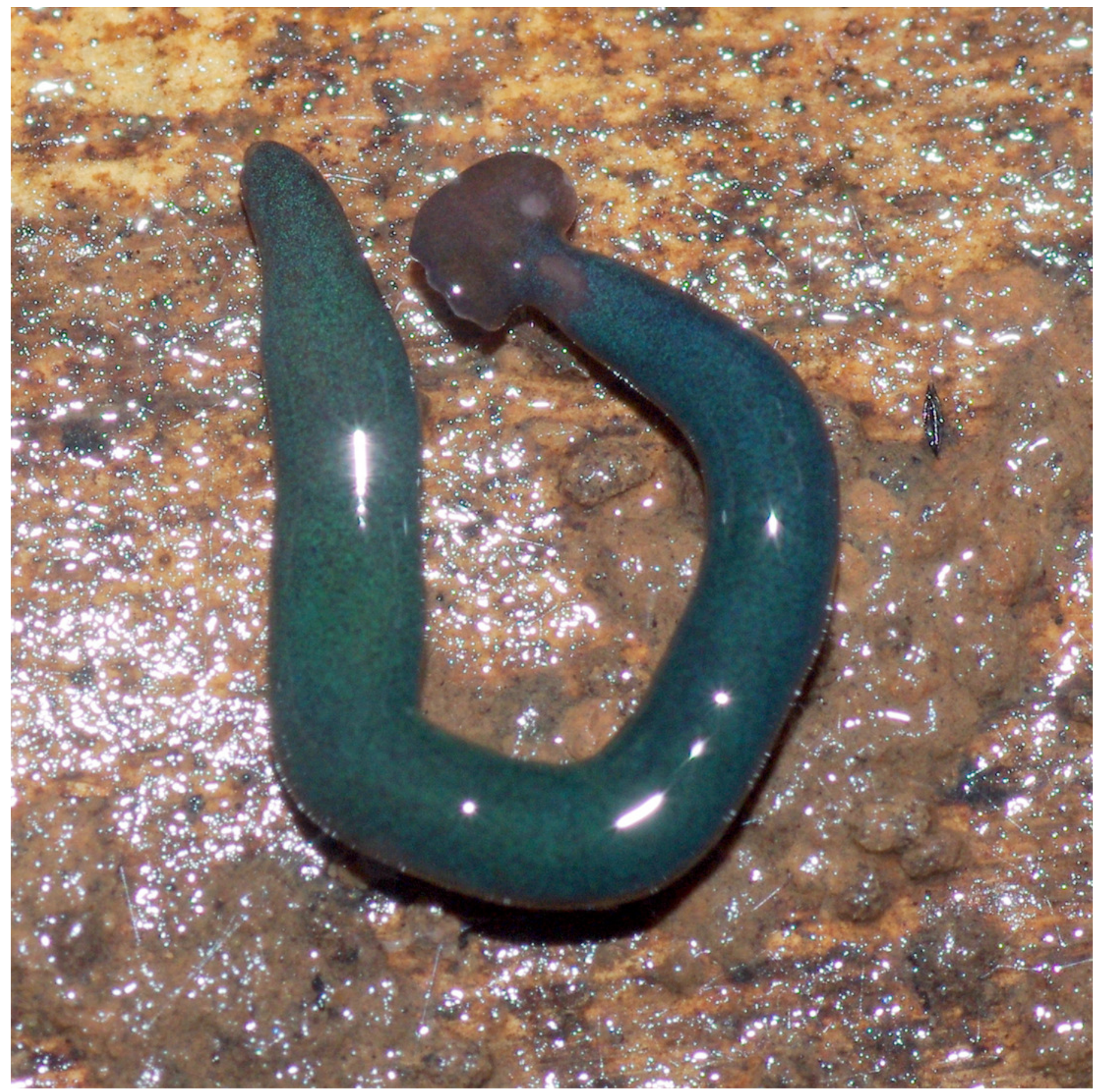




\section{Figure 26}

Diversibipalium mayottensis $\mathrm{n}$. sp, alive regenerating specimen.

Dorsal aspect of a regenerating specimen with a damaged anterior end. Specimen MNHN JL280. Under appropriate lighting, the colour of the specimen takes on a beautiful, almost metallic green colour. The iridescence and blue-green colour are lost on fixation, leaving the specimen a dark brown. Photo by Laurent Charles. Reproduced from Figure 25 in Justine et al., 2018 


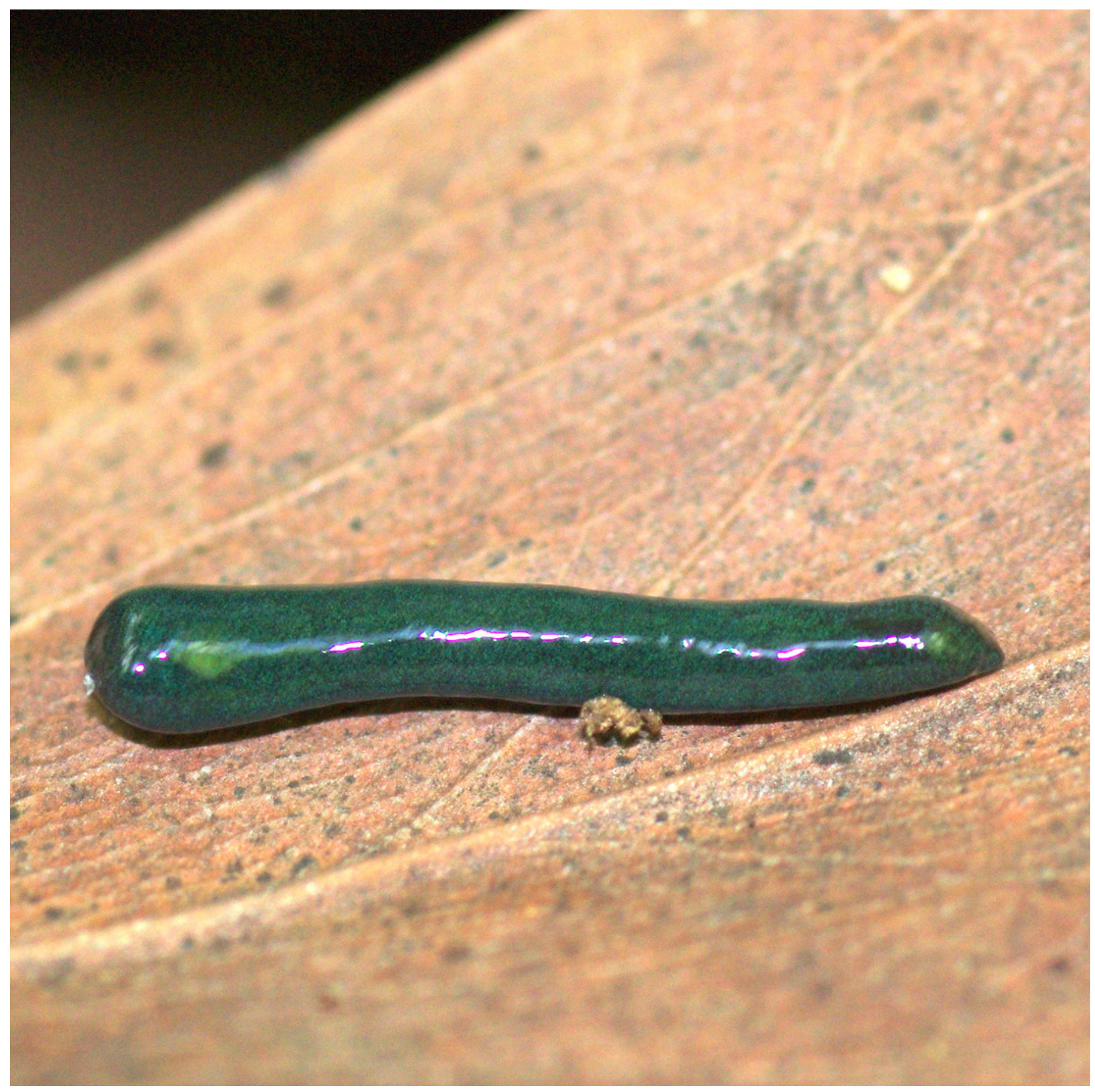




\section{Figure 27}

Diversibipalium mayottensis $\mathrm{n} . \mathrm{sp}$, alive regenerating specimen.

Dorsal aspect of a regenerating specimen with a damaged anterior end. Specimen MNHN JL280. A small portion of the brown-pigmented ventral surface with the median pale creeping sole can be seen. Photo by Laurent Charles. Reproduced from Figure 26 in Justine et al., 2018. 


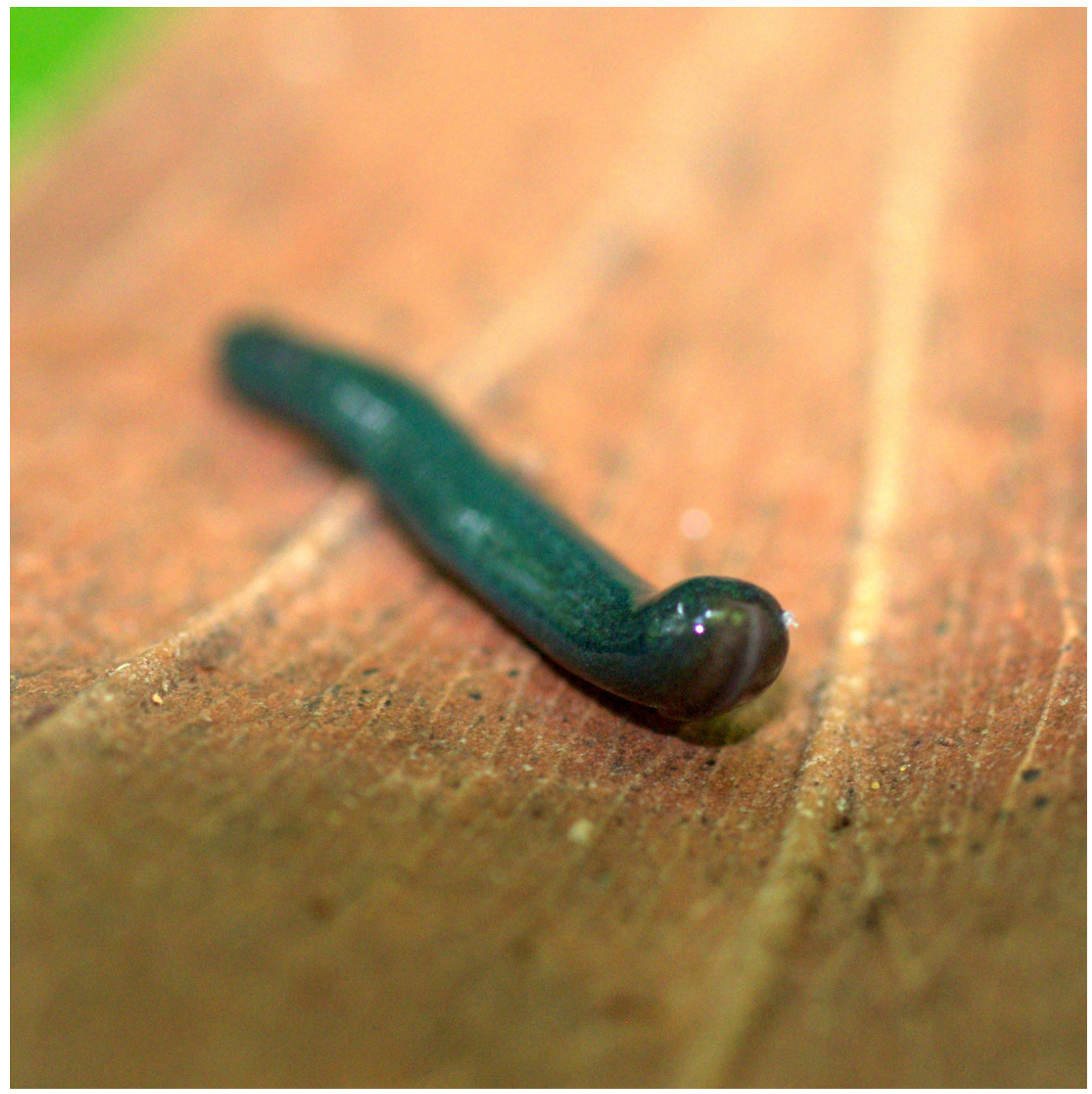




\section{Figure 28}

Mitogenome of Humbertium covidum n. sp.: genomic map of specimen MNHN JL351.

Specimen from the Italian population in Casier. The mitogenome is 15,540 bp long and contains 12 protein coding genes, two ribosomal RNA genes and 21 transfer RNA genes. The ND3 gene was found with a premature stop codon. 


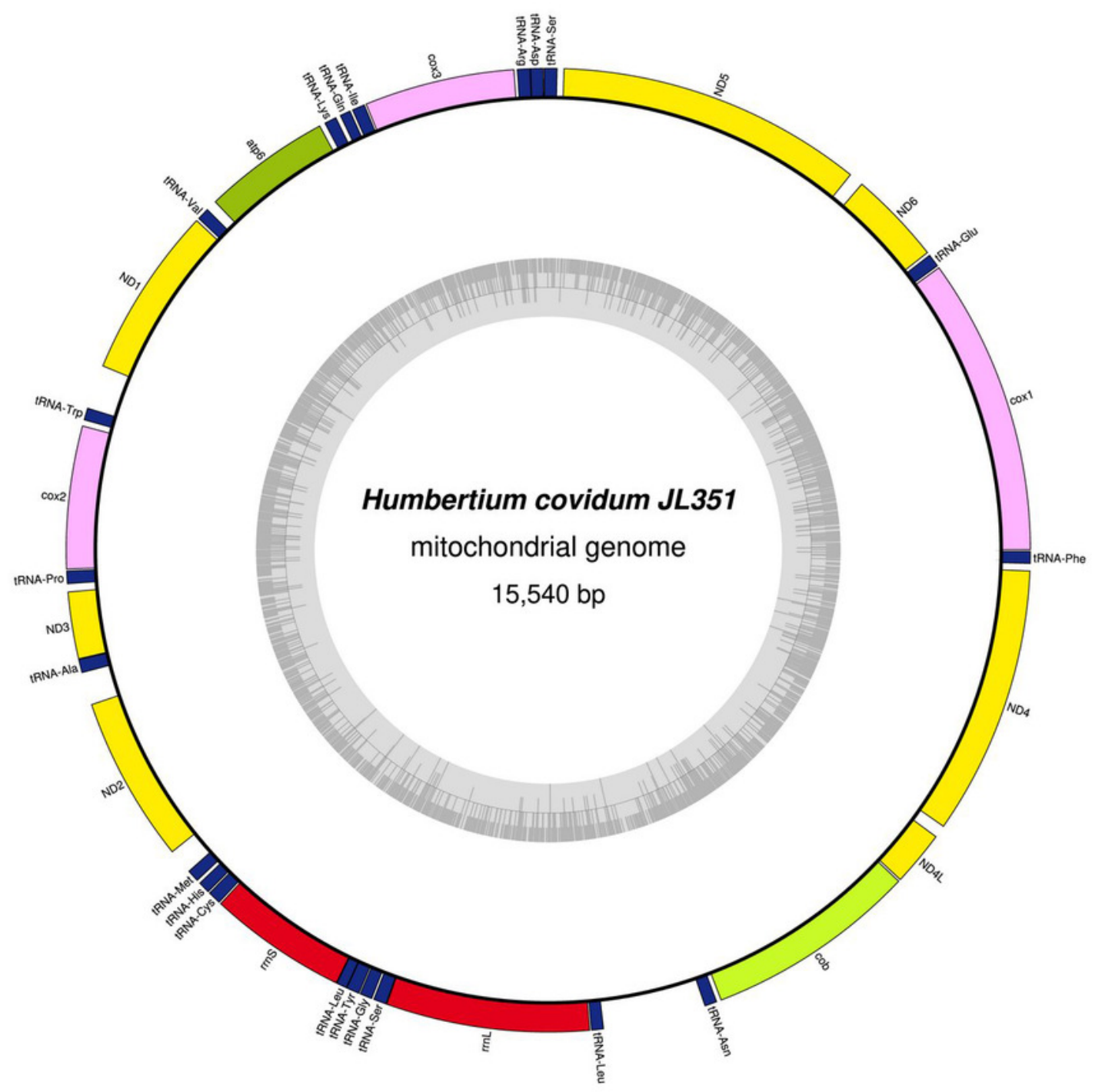

$\square$ complex I (NADH dehydrogenase)

complex III (ubichinol cytochrome c reductase)

complex IV (cytochrome c oxidase)

ATP synthase

ribosomal RNAs 


\section{Figure 29}

Mitogenome of Humbertium covidum n. sp.: genomic map of specimen MNHN JL090.

Specimen from the French population in Billère (Pyrénées-Atlantiques). The mitogenome is 15,524 bp long and contains 12 protein coding genes, two ribosomal RNA genes and 21 transfer RNA genes. The ND3 gene was found with a premature stop codon. 


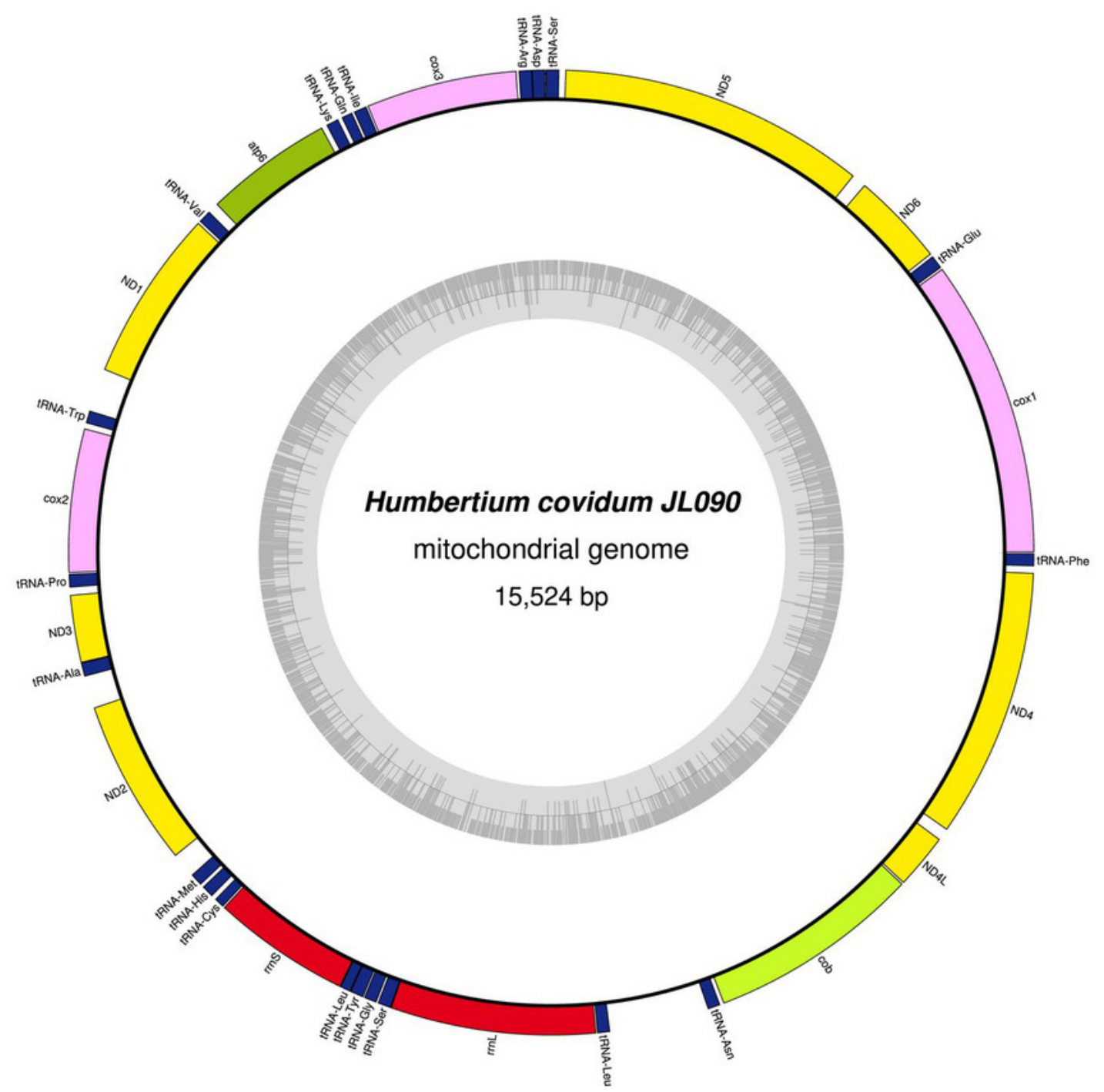

$\square$ complex I (NADH dehydrogenase)

complex III (ubichinol cytochrome c reductase)

complex IV (cytochrome c oxidase)

ATP synthase

ribosomal RNAs 
Figure 30

Mitogenome of Diversibipalium mayottensis n. sp.: genomic map of specimen JL281.

The mitogenome is $15,989 \mathrm{bp}$ long and contains 12 protein coding genes, two ribosomal RNA genes and 22 transfer RNA genes.

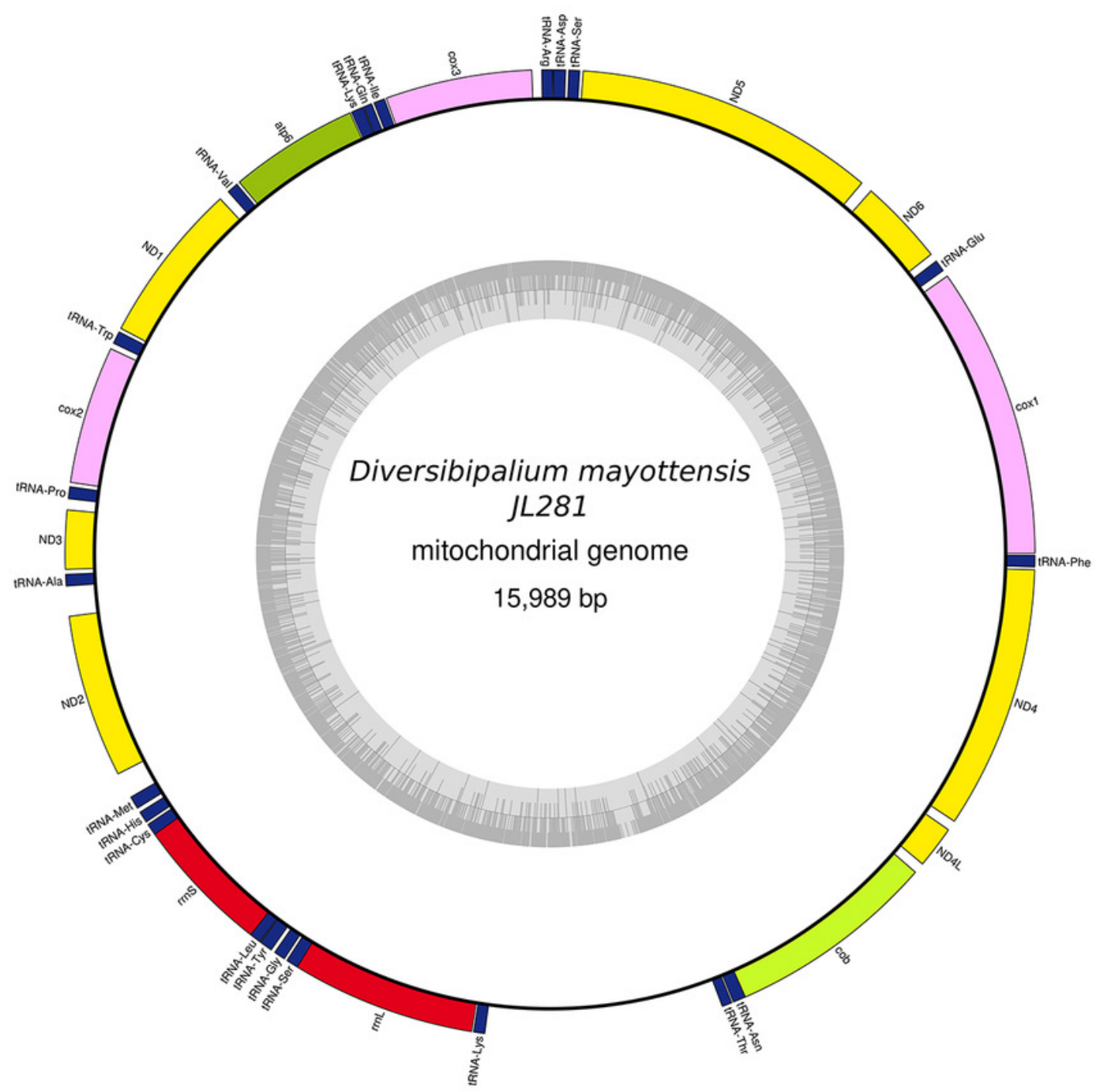

$\square$ complex I (NADH dehydrogenase)

complex III (ubichinol cytochrome c reductase)

$\square$ complex IV (cytochrome c oxidase)

ATP synthase

transfer RNAs 
Figure 31

Mitogenome of Bipalium vagum.: genomic map of specimen JL307.

The mitogenome is 17,149 bp long and contains 12 protein coding genes, two ribosomal RNA genes and 22 transfer RNA genes. The genes cox3, atp6, ND1, ND4L have alternative start codon. 


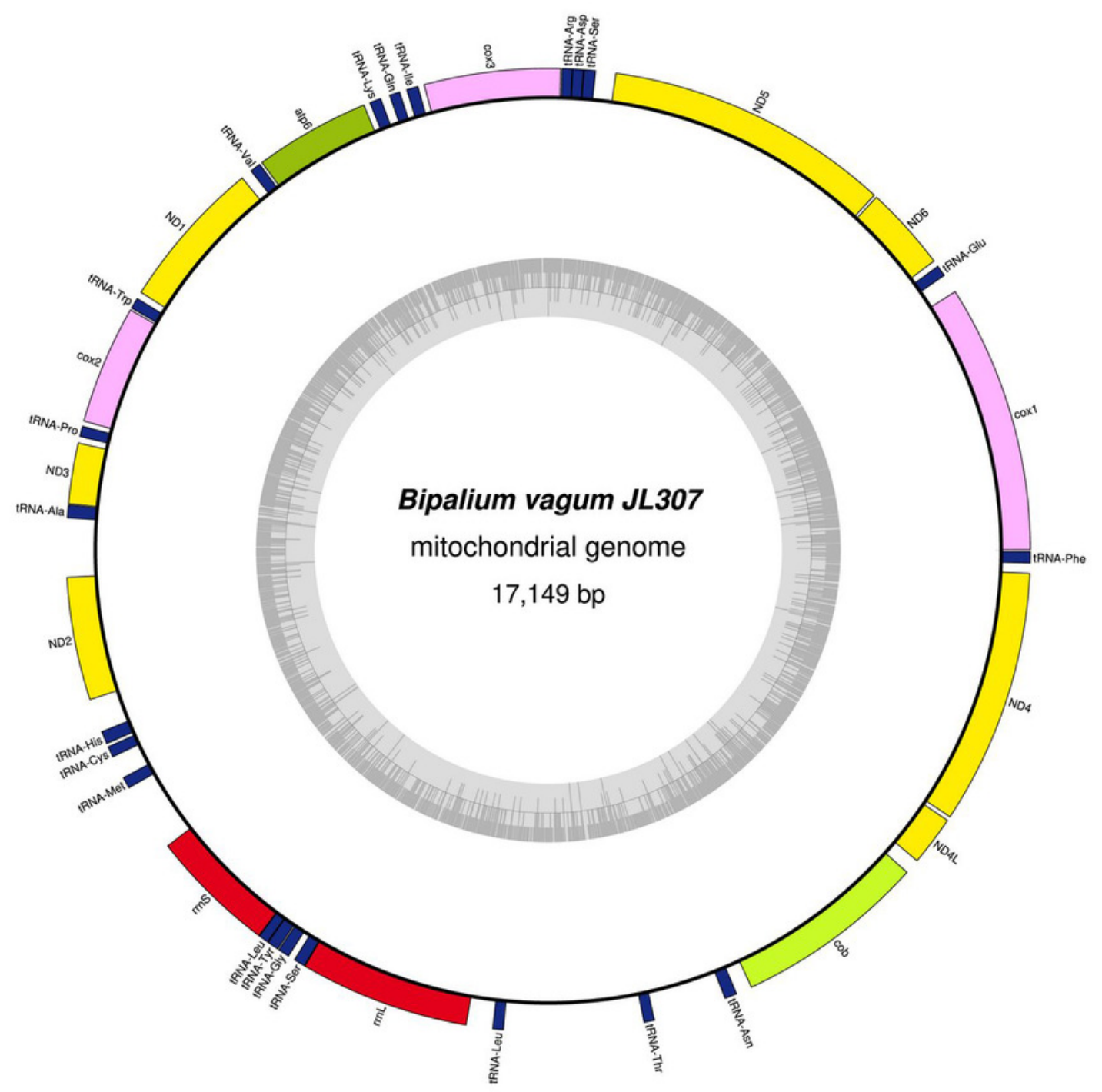

$\square$ complex I (NADH dehydrogenase)

complex III (ubichinol cytochrome c reductase)

complex IV (cytochrome c oxidase)

ATP synthase

ribosomal RNAs 
Figure 32

Mitogenome of Bipalium adventitium: genomic map of specimen JL328.

The mitogenome is $15,494 \mathrm{bp}$ long and contains 12 protein coding genes, two ribosomal RNA genes and 21 transfer RNA genes. It was not possible to find a stop codon for the cob gene. 


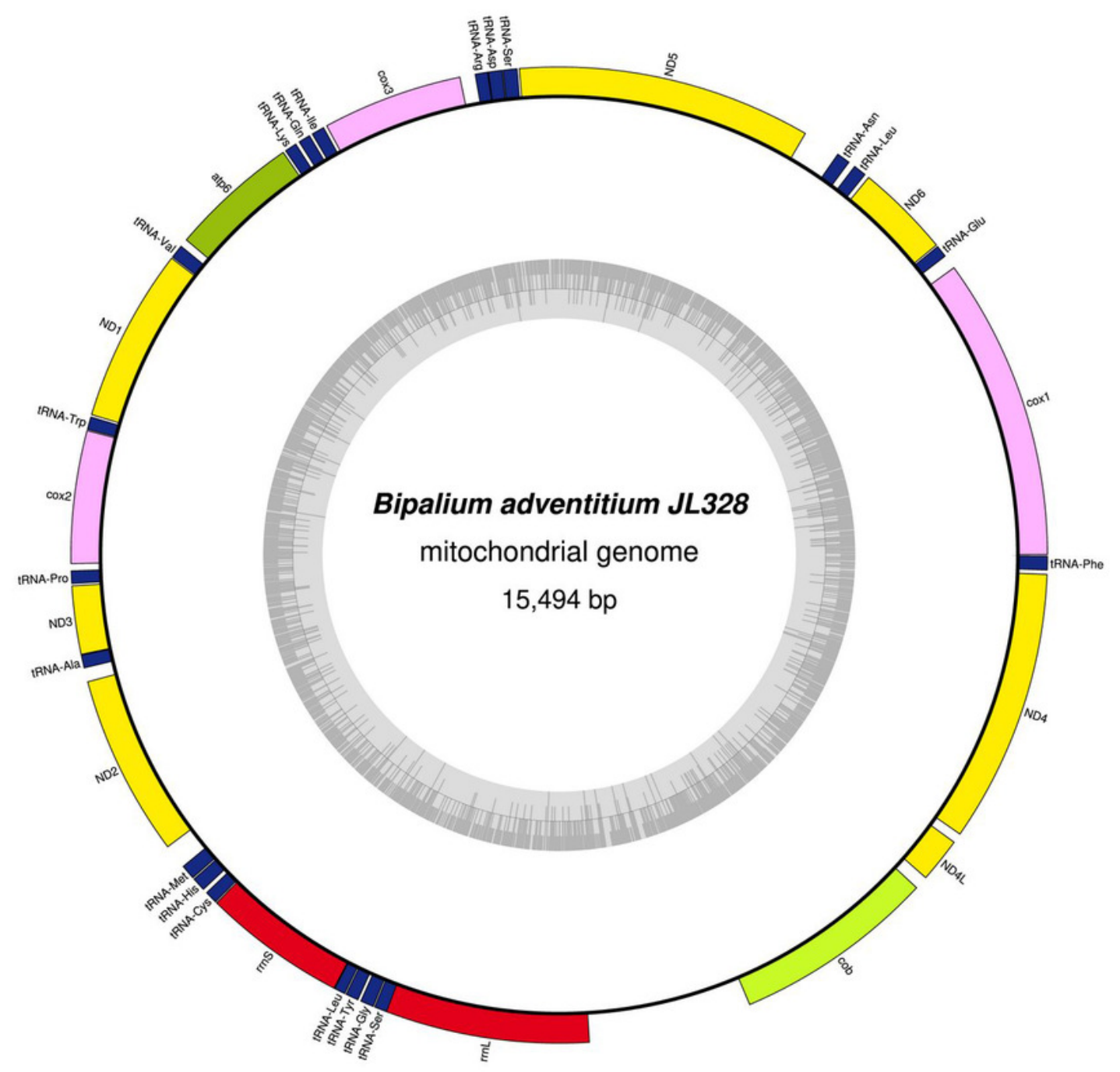

$\square$ complex I (NADH dehydrogenase)

complex III (ubichinol cytochrome c reductase)

complex IV (cytochrome c oxidase)

ATP synthase

ribosomal RNAs 
Figure 33

Mitogenome of Diversibipalium multilineatum: genomic map of specimen JL177.

The mitogenome is not complete. The size of the partial genome is $15,660 \mathrm{bp}$ long and contains 12 protein coding genes, two ribosomal RNA genes and 21 transfer RNA genes. The genes ND2 and ND3 have alternative start codon.

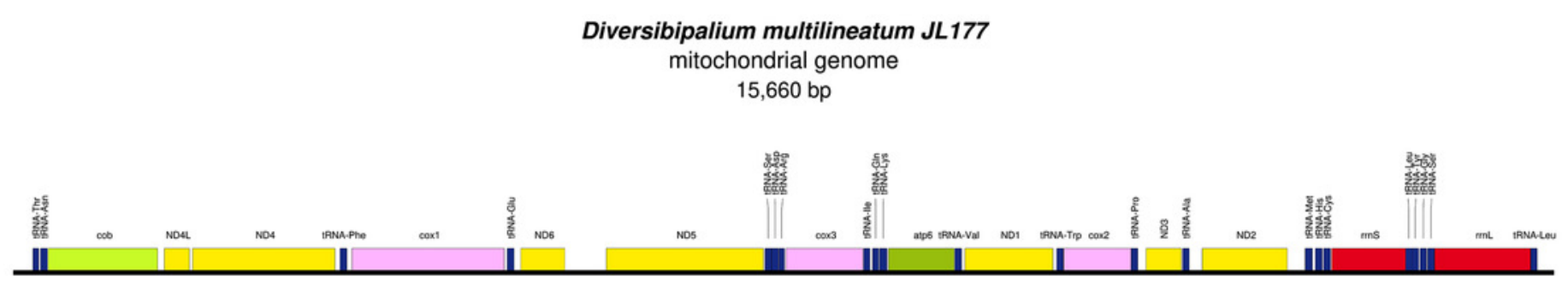


Figure 34

Mitogenome of Bipalium kewense: genomic map of specimen JL184A.

The mitogenome is 15,666 bp long and contains 12 protein coding genes, two ribosomal RNA genes and 22 transfer RNA genes. 


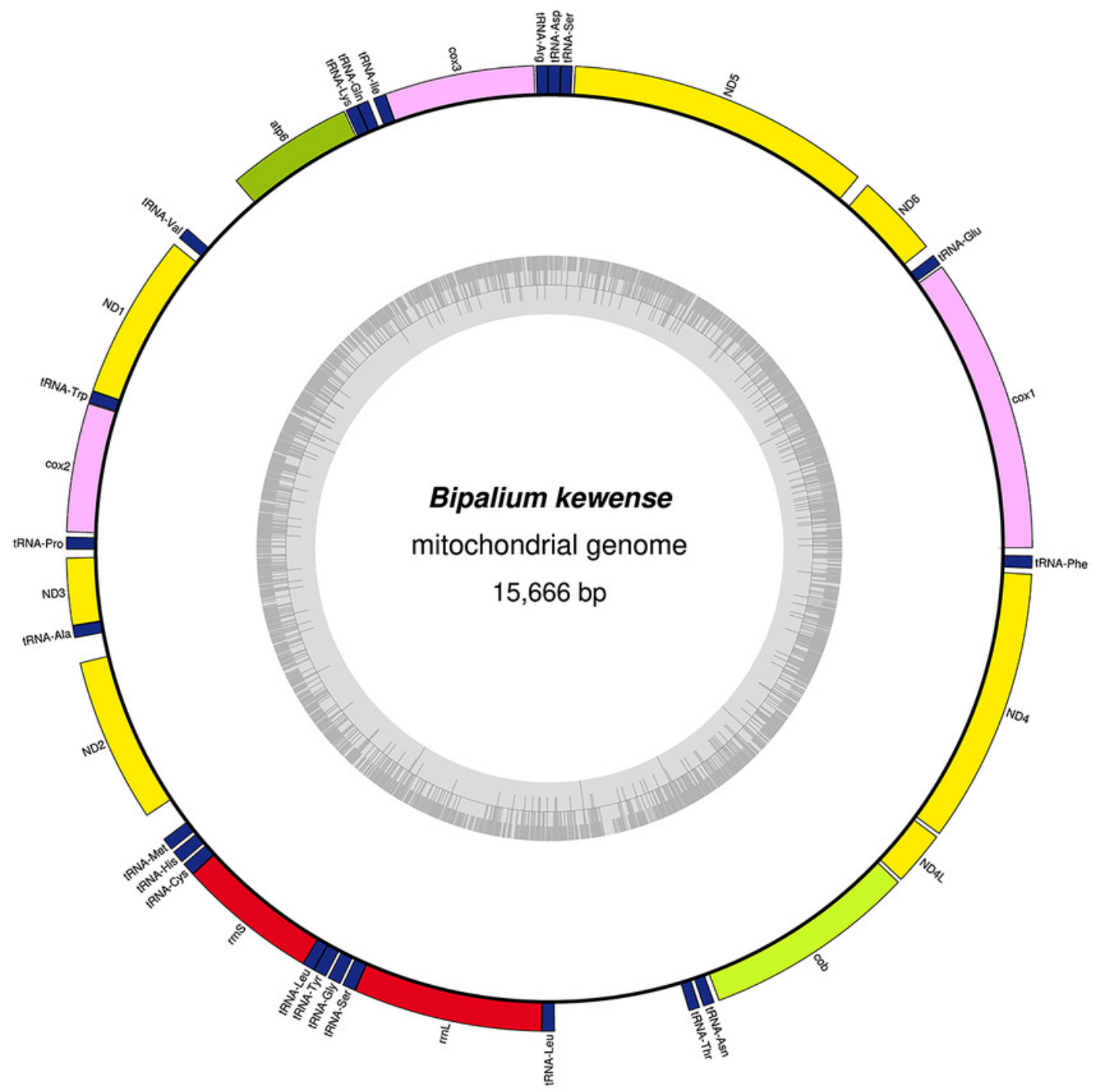

$\square$ complex I (NADH dehydrogenase)

complex III (ubichinol cytochrome c reductase)

complex IV (cytochrome c oxidase)

ATP synthase

ribosomal RNAs 


\section{Figure 35}

An alignment of the 'complete' 16S genes from all Bipaliinae displayed as a LOGO.

The alignment obtained from 7 sequences representing 6 species shows the presence of a more conserved second part of the gene while the first part appears strongly variable.

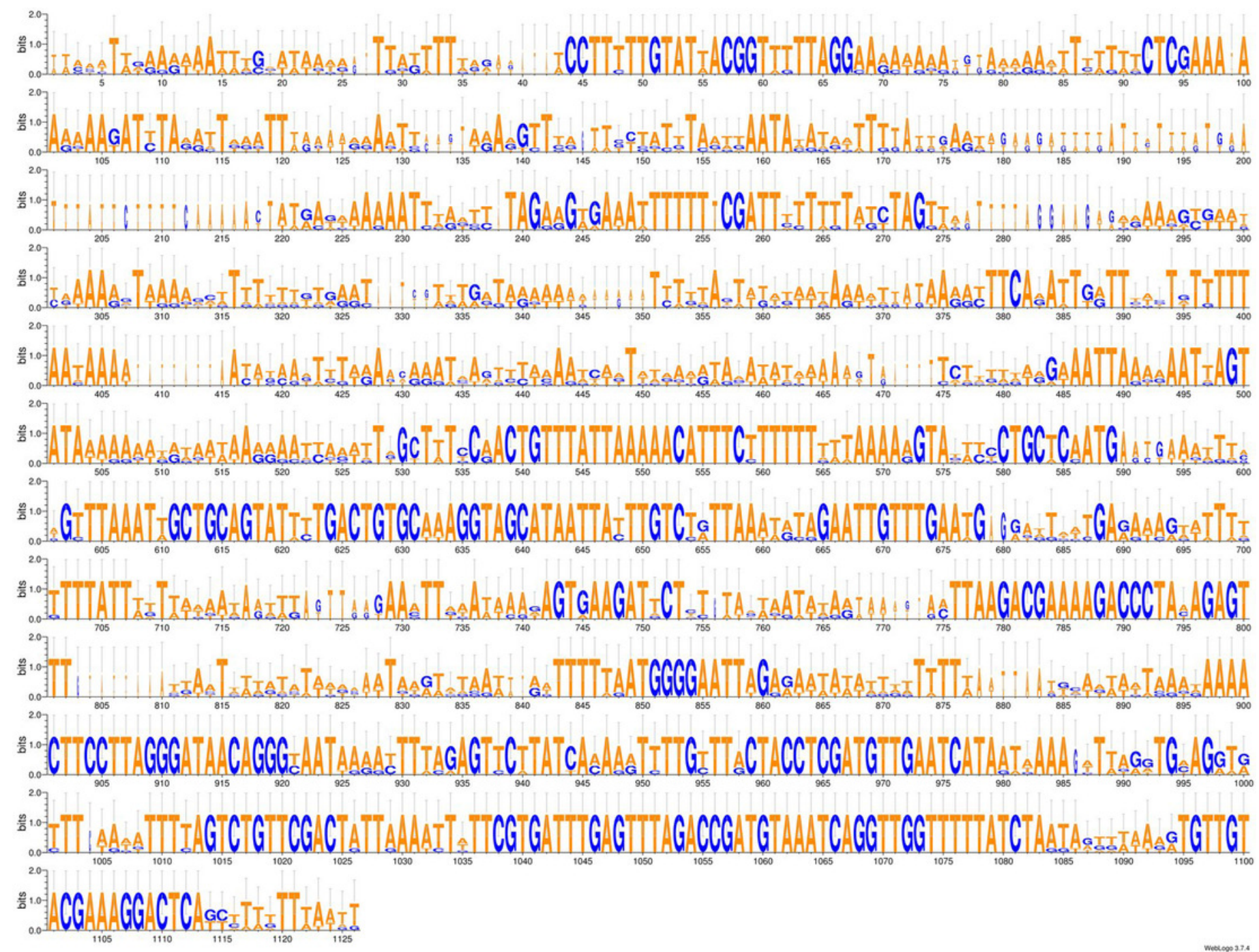




\section{Figure 36}

Alignments of the 'complete' 16S genes from H. covidum JL090 and JL351.

The two specimens are from the French (JL090) and Italian (JL351) populations. The black star indicates the beginning of the most conserved part evidenced by multispecies alignment.

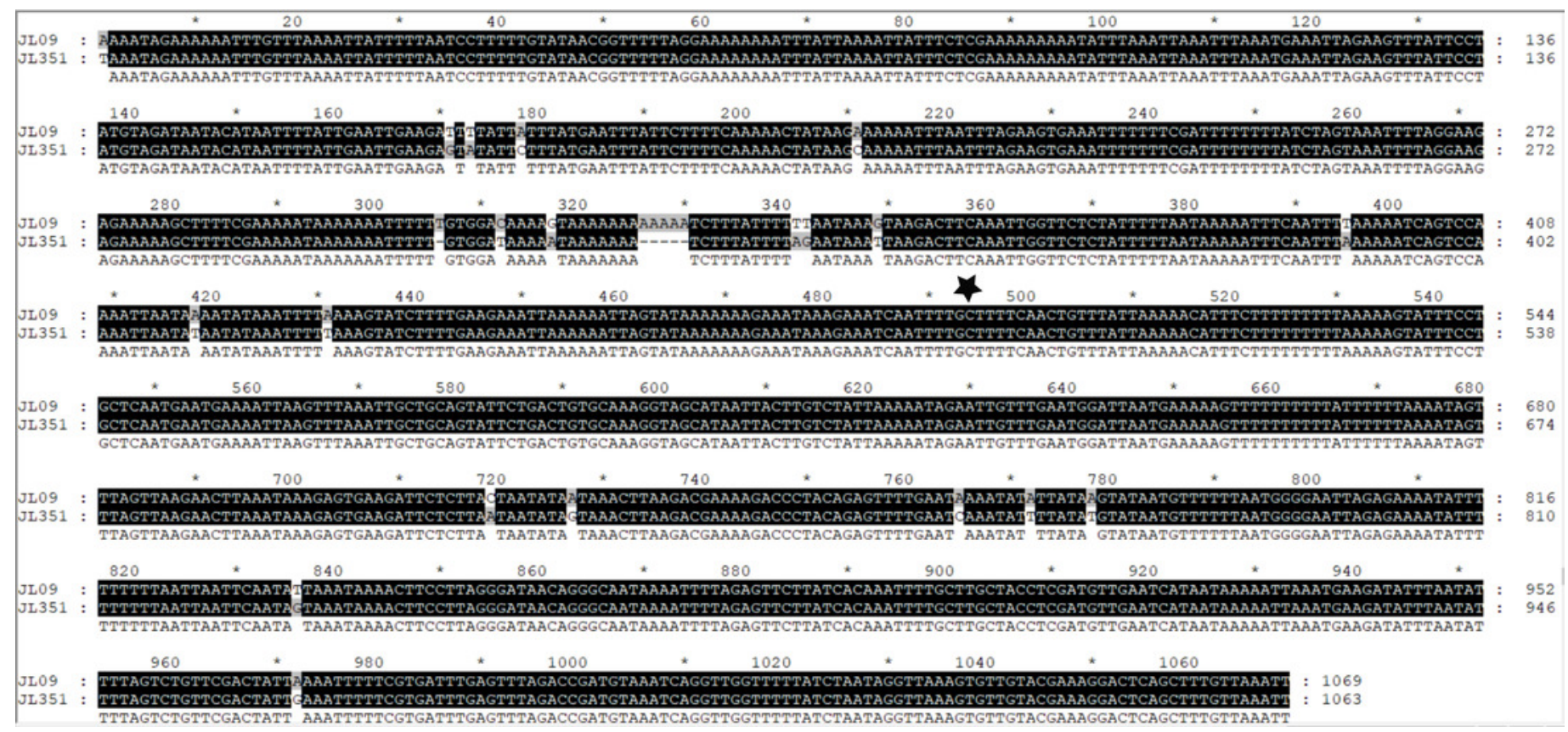




\section{Figure 37}

SSU phylogenetic tree of bipaliine geoplanids.

Maximum likelihood phylogenetic tree based on 14 partial SSU genes, using the GTR+I+G model of evolution, with the best tree out of 100 computed for 1000 bootstrap replications. The tree with the best likelihood is shown (-2551.353092). ML bootstrap support values on the left. The BI tree had and identical topology, posterior probabilities are indicated on the right as decimal values. Diversibipalium mayottensis n. sp. appears as the sister-group to all other bipaliines. The subfamilies within the Geoplanidae (Rhynchodeminae, Geoplaninae and Bipaliinae) are indicated. Diversibipalium mayottensis branch in bold to show its position as sister-group to all other Bipaliinae. 


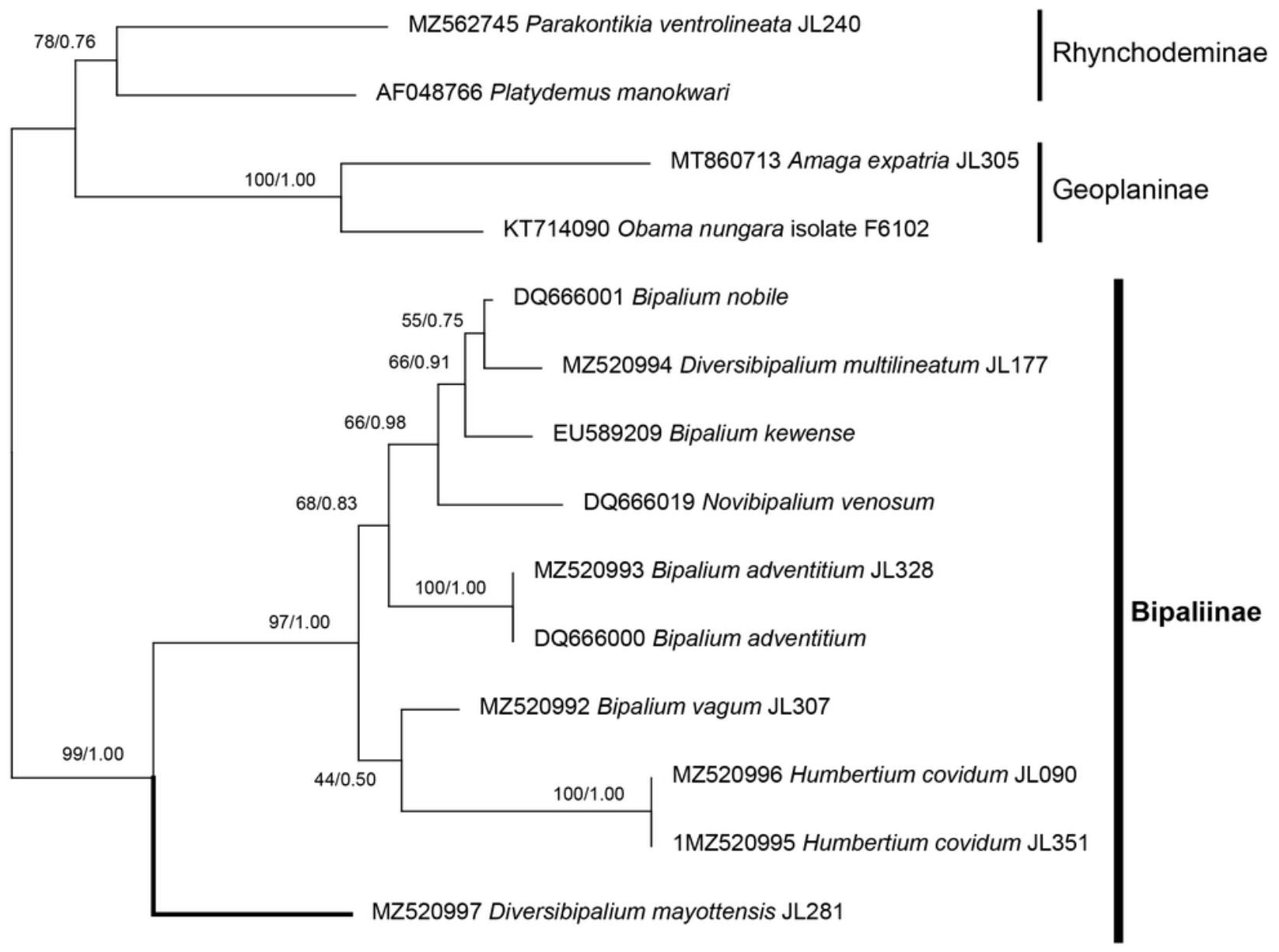

0.02 


\section{Figure 38}

LSU phylogenetic tree of bipaliine geoplanids.

Maximum likelihood phylogenetic tree based on 20 partial LSU genes, using the GTR $+I+G$ model of evolution, with the best tree out of 100 computed for 1000 bootstrap replications. The tree with the best likelihood is shown (-4759.571033). ML bootstrap support values on the left. The BI tree had identical topology; posterior probabilities are indicated on the right as decimal values. The subfamilies within the Geoplanidae (Rhynchodeminae, Geoplaninae and Bipaliinae) are indicated. Diversibipalium mayottensis branch in bold to show its position as sister-group to all other Bipaliinae.

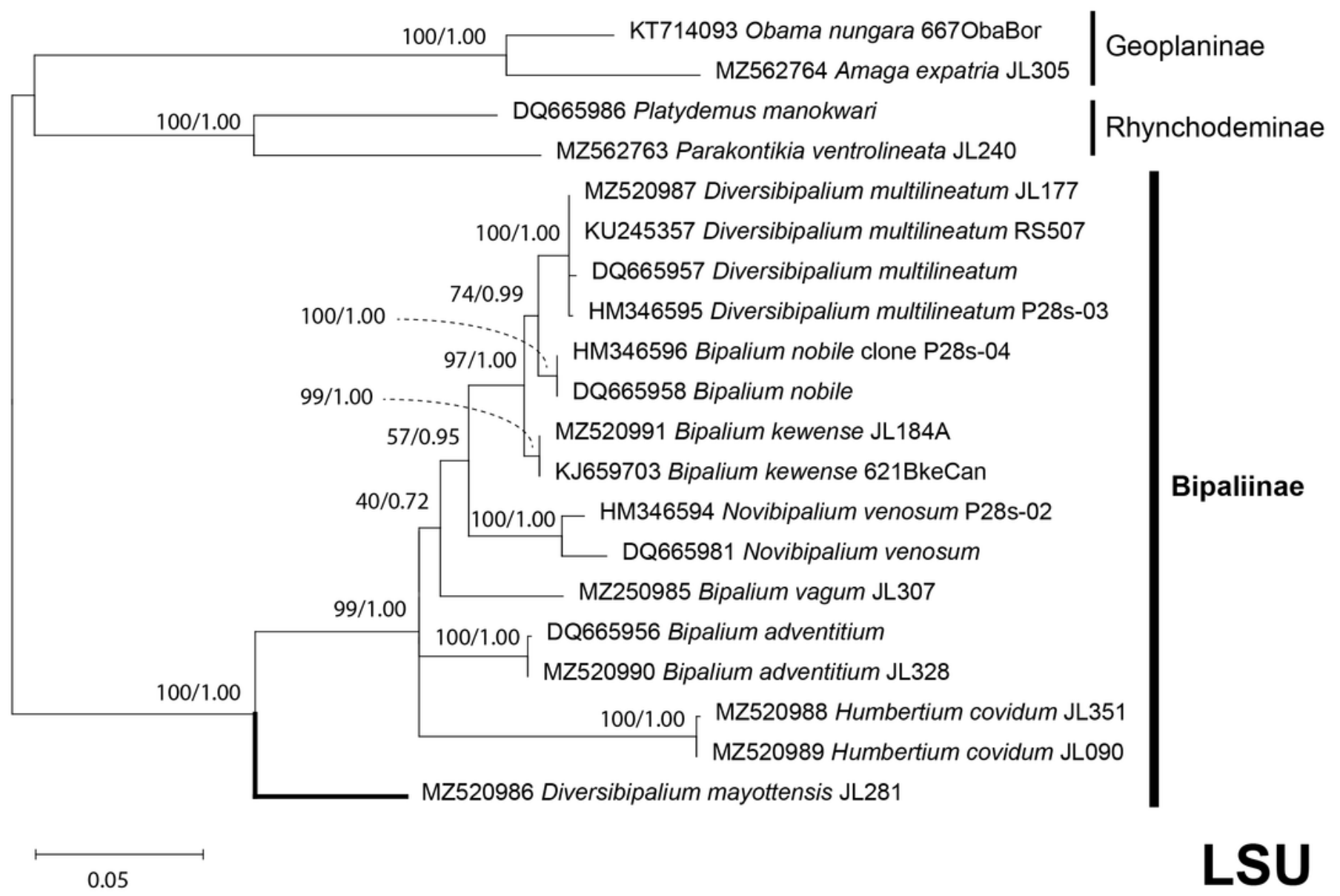




\section{Figure 39}

Phylogenetic tree of concatenated mitochondrial proteins of bipaliin geoplanids.

Maximum likelihood phylogenetic tree based on concatenated protein sequences extracted from 19 mitogenomes using the mtART $+I+G$ model, with the best tree out of 100 computed for 1000 bootstrap replications. The tree with the best likelihood is shown (-4759.571033). The subfamilies within the Geoplanidae (Rhynchodeminae, Geoplaninae and Bipaliinae) are indicated. Diversibipalium mayottensis branch in bold to show its position as sister-group to all other Bipaliinae.

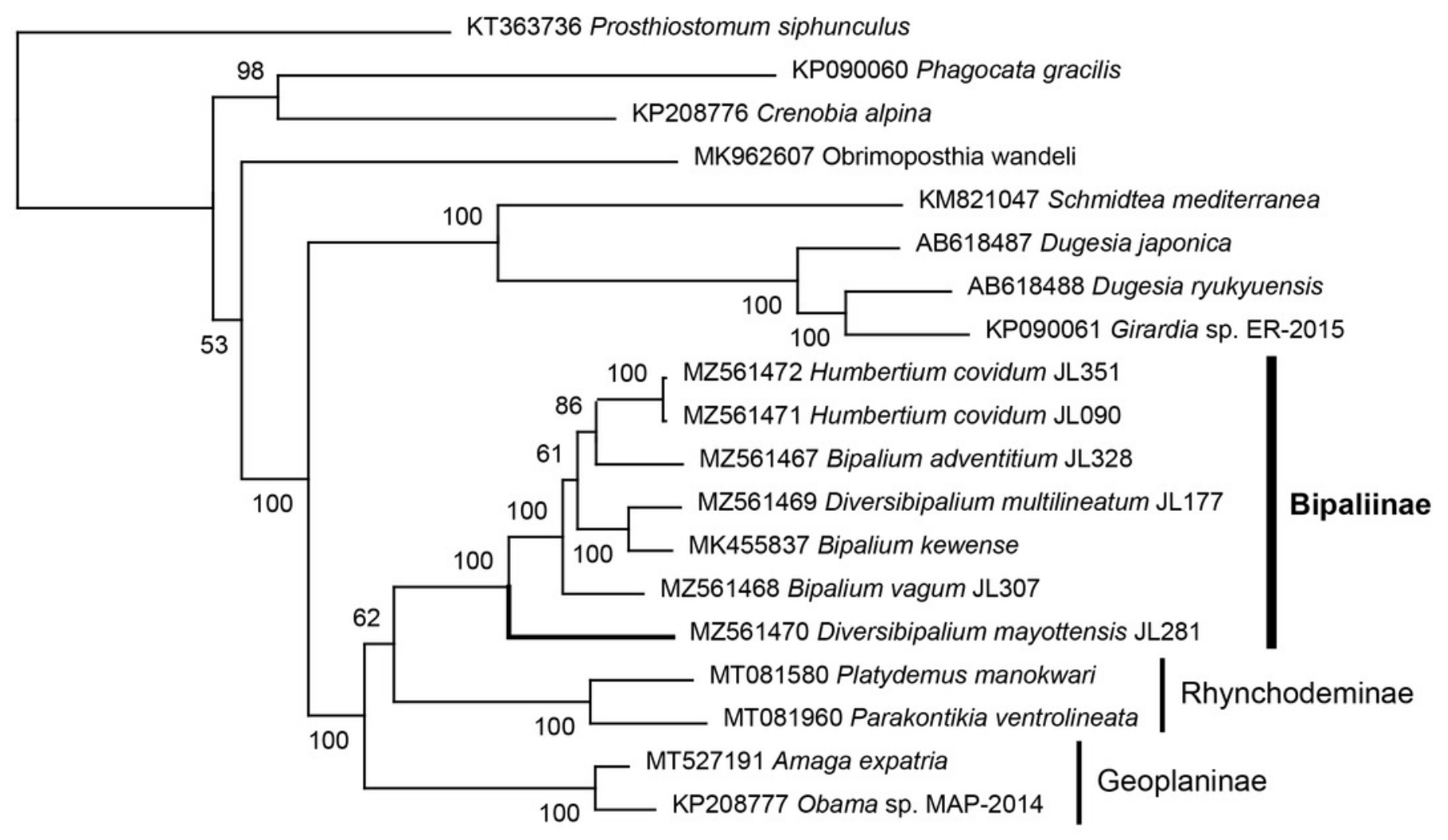




\section{Figure 40}

Three-gene phylogenetic tree of bipaliine geoplanids, based on concatenated cox1, SSU and LSU genes.

Maximum likelihood phylogenetic tree based on 18 concatenated partial sequences of cox 1 , SSU and LSU, using the GTR+I+G model of evolution, with the best tree out of 100 computed for 1000 bootstrap replications. The tree with the best likelihood is shown (-24779.059136). ML bootstrap support values on the left. The BI tree had identical topology; posterior probabilities are indicated on the right as decimal values. The subfamilies within the Geoplanidae (Rhynchodeminae, Geoplaninae and Bipaliinae) are indicated. Diversibipalium mayottensis branch in bold to show its position as sister-group to all other Bipaliinae.

Prosthiostomum siphunculus

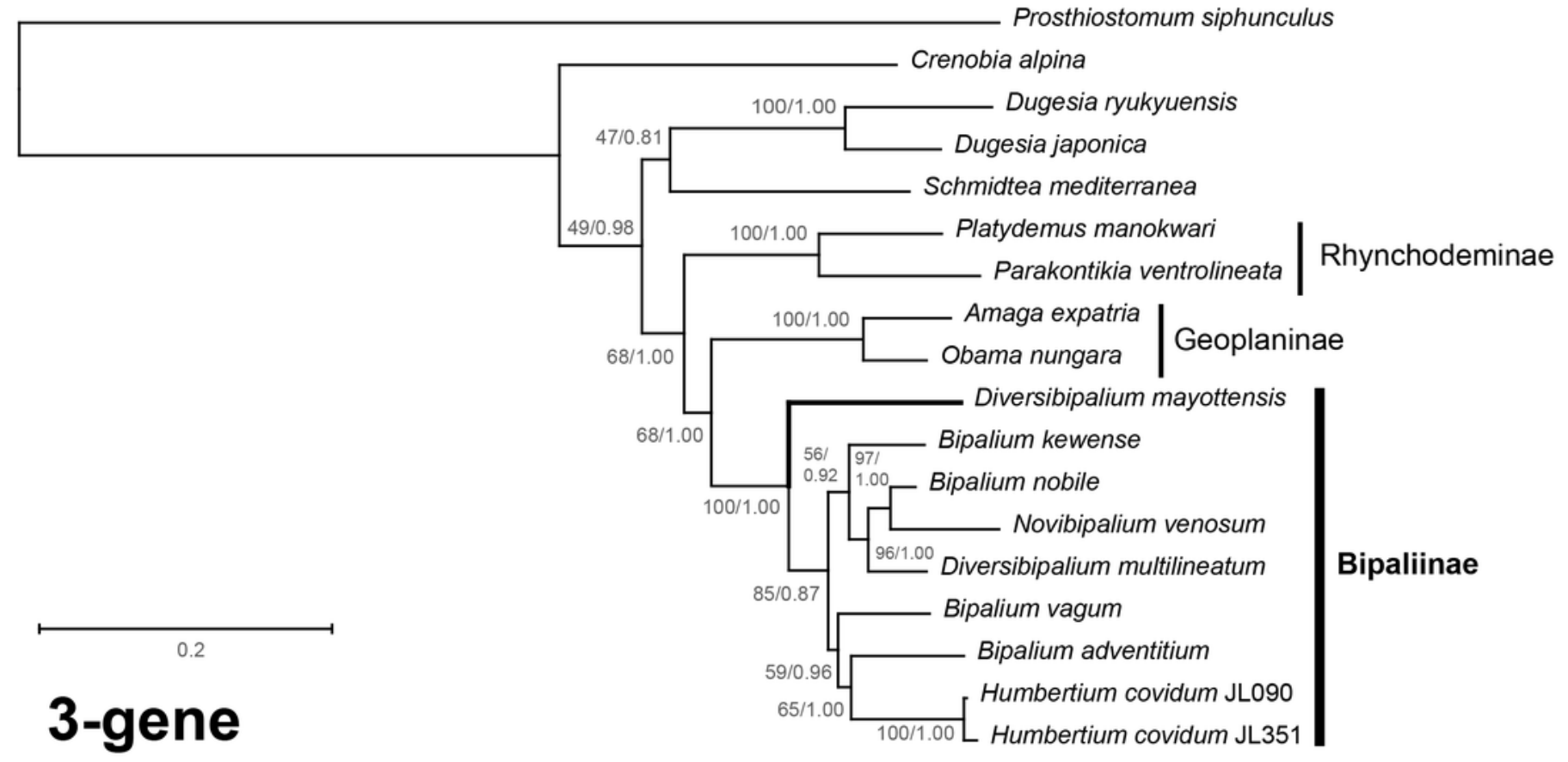




\section{Table $\mathbf{1}$ (on next page)}

Hammerhead flatworms (Geoplanidae, Bipaliinae), authors of taxa and key references for biology and mitogenome.

The list includes the main invasive taxa and the species studied here. 


\begin{tabular}{|c|c|c|c|}
\hline Taxon and authors & Reference for taxon & $\begin{array}{l}\text { Main references for } \\
\text { biology }\end{array}$ & $\begin{array}{l}\text { Mitochondrial } \\
\text { genome }\end{array}$ \\
\hline Bipalium kewense Moseley, 1878 & Moseley 1878 & Winsor 1983 & $\begin{array}{l}\text { (Gastineau et al. } \\
\text { 2019) }\end{array}$ \\
\hline Bipalium vagum Jones \& Sterrer, 2005 & Jones \& Sterrer 2005 & Ducey et al. 2007 & This paper \\
\hline Bipalium adventitium Hyman, 1943 & Hyman 1943 & Ducey et al. 2005 & This paper \\
\hline Bipalium pennsylvanicum Ogren, 1987 & Ogren 1987 & $\begin{array}{l}\text { Ogren \& Sheldon } \\
1991\end{array}$ & Unknown \\
\hline $\begin{array}{l}\text { Diversibipalium multilineatum } \\
\text { (Makino \& Shirasawa, 1983) Kubota } \\
\& \text { Kawakatsu, } 2010\end{array}$ & $\begin{array}{l}\text { Makino \& Shirasawa } \\
1983\end{array}$ & $\begin{array}{l}\text { Makino \& Shirasawa } \\
1986\end{array}$ & This paper \\
\hline Humbertium covidum n. sp. & This paper & $\begin{array}{l}\text { Justine et al. 2018; } \\
\text { This paper }\end{array}$ & This paper \\
\hline Diversibipalium mayottensis $\mathrm{n} . \mathrm{sp}$. & This paper & $\begin{array}{l}\text { Justine et al. 2018; } \\
\text { This paper }\end{array}$ & This paper \\
\hline
\end{tabular}




\section{Table 2 (on next page)}

Humbertium covidum n. sp.: dimensions of specimens examined.

Positions of body apertures are measured from the anterior tip. Figures in parentheses are the position of the aperture expressed as a percentage of body length. NM: not measured. 


\begin{tabular}{|c|c|c|c|c|c|c|}
\hline Fixed specimen dimensions & $\begin{array}{l}\text { Holotype } \\
\text { JL 351A }\end{array}$ & $\begin{array}{l}\text { Paratype } \\
\text { JL 351A }\end{array}$ & $\begin{array}{l}\text { Paratype } \\
\text { JL 351A }\end{array}$ & $\begin{array}{l}\text { Paratype } \\
\text { JL 351A }\end{array}$ & $\begin{array}{l}\text { Paratype } \\
\text { JL 351A }\end{array}$ & $\begin{array}{l}\text { Voucher } \\
\text { JL } 090\end{array}$ \\
\hline Geographic origin & Italy & Italy & Italy & Italy & Italy & France \\
\hline Length $(\mathrm{mm})$ & 13.3 & 12.0 & 13.2 & 12.8 & 9.0 & 20.0 \\
\hline Width of headplate (mm) & 2.0 & NM & 2.0 & 2.0 & 2.0 & NM \\
\hline Width at mouth $(\mathrm{mm})$ & 2.5 & 2.1 & 2.5 & 2.5 & 2.4 & 3.2 \\
\hline Ratio width headplate to body width & $0.8: 1$ & - & $0.8: 1$ & $0.8: 1$ & $0.8: 1$ & - \\
\hline Ratio body width to length & $1: 5.3$ & $1: 5.7$ & $1: 5.3$ & $1: 5.1$ & $1: 4.5$ & $1: 6.3$ \\
\hline Mouth (mm) & $5.0(37.6)$ & $5.6(46.7)$ & $\begin{array}{l}6.5 \\
(49.2)\end{array}$ & $\begin{array}{l}6.0 \\
(46.9)\end{array}$ & $\begin{array}{l}6.0 \\
(66.7)\end{array}$ & $\begin{array}{l}6.0 \\
(30.0)\end{array}$ \\
\hline Gonopore (mm) & $7.1(53.4)$ & $7.5(62.5)$ & $\begin{array}{l}8.2 \\
(62.1)\end{array}$ & $\begin{array}{l}7.8 \\
(60.9)\end{array}$ & $\begin{array}{l}7.4 \\
(82.2)\end{array}$ & $\begin{array}{l}7.8 \\
(39.0)\end{array}$ \\
\hline Distance mouth-gonopore (mm) & $2.1(15.8)$ & $1.9(19)$ & $\begin{array}{l}1.7 \\
(12.9)\end{array}$ & $\begin{array}{l}1.8 \\
(14.1)\end{array}$ & $\begin{array}{l}1.4 \\
(15.6)\end{array}$ & $1.8(9)$ \\
\hline Body Height $\mu \mathrm{m}$ & 1157 & 741 & & & & \\
\hline Creeping sole width $\mu \mathrm{m}$ (\% body width) & $\begin{array}{l}1157 \\
(30.8 \%)\end{array}$ & $\begin{array}{l}647 \\
(21.6 \%)\end{array}$ & & & & \\
\hline CMI & $2 \%$ & $3.2 \%$ & & & & \\
\hline PMI & $8.4 \%$ & $15 \%$ & & & & \\
\hline Pharynx type & Collar & $\begin{array}{l}\text { Bell - } \\
\text { Collar }\end{array}$ & & & & \\
\hline Pharyngeal pouch length (\% body length) & $\begin{array}{l}1068 \mu \mathrm{m} \\
(8 \%)\end{array}$ & $\begin{array}{l}1287 \mu \mathrm{m} \\
(10 \%)\end{array}$ & & & & \\
\hline Position of mouth in pharyngeal pouch & $\begin{array}{l}623 \mu \mathrm{m} \\
(58.5 \%)\end{array}$ & $\begin{array}{l}624 \mu \mathrm{m} \\
(48.5 \%)\end{array}$ & & & & \\
\hline $\begin{array}{l}\text { Distance between posteriad pharyngeal } \\
\text { pouch and anteriad penis bulb }\end{array}$ & $250 \mu \mathrm{m}$ & $590 \mu \mathrm{m}$ & & & & \\
\hline
\end{tabular}


Table 3 (on next page)

Characteristics of mitogenomes of bipaliines. 


\begin{tabular}{|c|c|c|c|c|c|}
\hline Species & $\begin{array}{l}\text { MNHN } \\
\text { registration } \\
\text { number }\end{array}$ & $\begin{array}{l}\text { GenBank } \\
\text { accession } \\
\text { number }\end{array}$ & $\begin{array}{l}\text { Size of the } \\
\text { mitogenome }\end{array}$ & Early stop & Alternative start codon \\
\hline Humbertium covidum & JL351 & MZ561472 & $15540 \mathrm{bp}$ & $N D 3$ & - \\
\hline Humbertium covidum & JL090 & MZ561471 & $15524 \mathrm{bp}$ & $N D 3$ & - \\
\hline Diversibipalium mayottensis & JL281 & MZ561470 & $15989 \mathrm{bp}$ & - & - \\
\hline Bipalium vagum & JL307 & MZ561468 & $17149 \mathrm{bp}$ & - & cox3, atp6, ND1, ND4L \\
\hline $\begin{array}{l}\text { Diversibipalium } \\
\text { multilineatum }\end{array}$ & JL177 & MZ561469 & $\begin{array}{l}15660 \mathrm{bp} \\
\text { (not complete) }\end{array}$ & - & $N D 2, N D 3$ \\
\hline Bipalium adventitium & JL328 & MZ561467 & $15494 \mathrm{bp}$ & $c o b$ & - \\
\hline Bipalium kewense & JL184A & MK455837 & $15666 \mathrm{bp}$ & - & - \\
\hline
\end{tabular}




\section{Table 4 (on next page)}

Genetic differences between two populations (JL351, Italy vs JL090, France) of Humbertium covidum. 


\begin{tabular}{|c|c|c|c|c|c|c|c|c|c|c|c|c|}
\hline & atp6 & $c o b$ & $\operatorname{cox} 1$ & $\cos 2$ & $\cos 3$ & $N D 1$ & ND2 & $N D 3$ & $N D 4$ & $N D 4 L$ & ND5 & ND6 \\
\hline $\begin{array}{l}\text { Polymorphic } \\
\text { site } \\
\text { (nucleotides) }\end{array}$ & $19 / 669$ & $36 / 1110$ & $35 / 1551$ & $20 / 747$ & $20 / 786$ & $19 / 897$ & $17 / 870$ & $6 / 352$ & $27 / 1407$ & $8 / 291$ & $46 / 1599$ & $15 / 492$ \\
\hline $\begin{array}{l}\text { Percentage } \\
\text { of } \\
\text { differences } \\
\text { (nucleotides) }\end{array}$ & 2.84 & 3.24 & 2.25 & 2.68 & 2.54 & 2.19 & 1.95 & 1.70 & 1.92 & 2.75 & 2.88 & 3.05 \\
\hline $\begin{array}{l}\text { Polymorphic } \\
\text { sites (amino- } \\
\text { acids) }\end{array}$ & $8 / 222$ & $7 / 369$ & $3 / 516$ & $4 / 248$ & $1 / 261$ & $7 / 298$ & $4 / 289$ & $2 / 117$ & $4 / 468$ & $3 / 96$ & $11 / 532$ & $7 / 163$ \\
\hline $\begin{array}{l}\text { Percentage } \\
\text { of } \\
\text { differences } \\
\text { (amino- } \\
\text { acids) }\end{array}$ & 3.60 & 1.90 & 0.58 & 1.61 & 0.38 & 2.34 & 1.38 & 1.70 & 0.85 & 3.125 & 2.07 & 4.29 \\
\hline
\end{tabular}




\section{Table 5 (on next page)}

Alien DNA detected in the samples. 


\begin{tabular}{|c|c|c|c|}
\hline $\begin{array}{l}\text { Sample and geographic } \\
\text { origin }\end{array}$ & $\begin{array}{l}\text { Contig size } \\
\text { (in bp) }\end{array}$ & Coverage & $\begin{array}{c}\text { Best blastn results (organism, accession } \\
\text { number, E-value, identity) }\end{array}$ \\
\hline H. covidum JL090 & 5953 & 87.595262 & Arion hortensis, KU341315, 0.0, 99.19\% \\
\hline \multirow[t]{3}{*}{ Billère, France } & 2209 & 20.638418 & Discus rotundatus, FJ917212, 0.0, 98.28\% \\
\hline & 2150 & 2.882324 & Arion hortensis, MG856341, 0.0, 99.77\% \\
\hline & 1624 & 72.587394 & Discus rotundatus, FJ917212, 0.0, 95.57\% \\
\hline H. covidum JL351 & 14281 & 3.216540 & $\begin{array}{l}\text { Cochlicopa lubrica (cox1 only), MF544766, } \\
0.0,99.24 \%\end{array}$ \\
\hline \multirow{4}{*}{ Casier, Italy } & 2140 & 93.634550 & Cochlicopa lubrica, AY014019, 0.0, 99.23\% \\
\hline & 633 & 136.802920 & Cochlicopa lubrica, GU331944, 0.0, 99.84\% \\
\hline & 413 & 113.274390 & Oxychilus alliarius, MN022707, 0.0, 97.64\% \\
\hline & 312 & 125.061674 & Various gastropods \\
\hline B. adventitium JL328 & 9730 & 52.980923 & Eisenia foetida, AF212166, 0.0, 98.87\% \\
\hline \multicolumn{4}{|l|}{ Montréal, Québec, } \\
\hline \multicolumn{4}{|l|}{ Canada } \\
\hline B. vagum JL307 & 5994 & 7.978338 & Subulina octona, MF444887, 0.0, 99.97\% \\
\hline Morne Vert, Martinique & 3025 & 22.415306 & Subulina striatella, MN022690, 0.0, 99.66\% \\
\hline
\end{tabular}




\section{Table 6(on next page)}

Humbertium covidum: possible occurrence worldwide.

The table provides a list of possible occurrences based on similarity of external morphology. All these records need to be confirmed, especially by molecular methods.

C/P: C, confirmed with molecular data; P, possible, based on photographs. 


\begin{tabular}{|c|c|c|c|c|}
\hline Locality, Country & Comments & Date & Reference & $\mathrm{C} / \mathrm{P}$ \\
\hline $\begin{array}{l}\text { Saint-Pée-sur-Nivelle, } \\
\text { France }\end{array}$ & & 2013 & Justine et al. 2018 & $\mathrm{C}$ \\
\hline Billère, France & & 2019 & This paper & C \\
\hline $\begin{array}{l}\text { Casier, Province of Treviso, } \\
\text { Italy }\end{array}$ & & 2019 & This paper & C \\
\hline $\begin{array}{l}\text { Kumamoto, Kyushu Island, } \\
\text { Japan }\end{array}$ & & 2000 & Kawakatsu et al. 2005 & $P$ \\
\hline $\begin{array}{l}\text { Marina di Cerveteri, } \\
\text { Province of Rome, Italy }\end{array}$ & $\begin{array}{l}\text { Photographs } \\
\text { form Citizen } \\
\text { Science }\end{array}$ & 2014 & Mori et al. 2021 & $P$ \\
\hline $\begin{array}{l}\text { Likander peninsula, Popov } \\
\text { Island, Eugénie Archipelago, } \\
\text { off Russia, Sea of Japan }\end{array}$ & $\begin{array}{l}\text { Based on their } \\
\text { Figure } 3\end{array}$ & 2017 & $\begin{array}{l}\text { Prozorova \& } \\
\text { Ternovenko } 2018\end{array}$ & $P$ \\
\hline $\begin{array}{l}\text { Xiamen, Chinese coast } \\
\text { facing Taiwan strait, P.R. } \\
\text { China }\end{array}$ & $\begin{array}{l}\text { iNaturalist } \\
\text { observation }\end{array}$ & 2018 & Observation \#19171303 & $P$ \\
\hline Xiamen, P.R. China & $\begin{array}{l}\text { iNaturalist } \\
\text { observation }\end{array}$ & 2018 & Observation \#19171787 & $P$ \\
\hline $\begin{array}{l}\text { Petrov Bay, Lazovsky Nature } \\
\text { Reserve, Primorye Territory, } \\
\text { Russia }\end{array}$ & $\begin{array}{l}\text { Based on her } \\
\text { Figure } 2 \mathrm{~A}\end{array}$ & 2019 & Prozorova 2021 & \\
\hline $\begin{array}{l}\text { Hachijö-jima Island, } \\
\text { Philippines Sea, off Japan } \\
\text { main islands }\end{array}$ & $\begin{array}{l}\text { Based on their } \\
\text { Figure } 2\end{array}$ & unknown & $\begin{array}{l}\text { Meyer-Rochow \& } \\
\text { Miinalainen } 2020\end{array}$ & $P$ \\
\hline
\end{tabular}

